UNIVERSIDADE DE SÃO PAULO

FACULDADE DE FILOSOFIA, LETRAS E CIÊNCIAS HUMANAS

DEPARTAMENTO DE LETRAS MODERNAS

PROGRAMA DE PÓS-GRADUAÇÃO EM LITERATURA ITALIANA

\title{
Zeno Cosini, uma identidade possível?
}

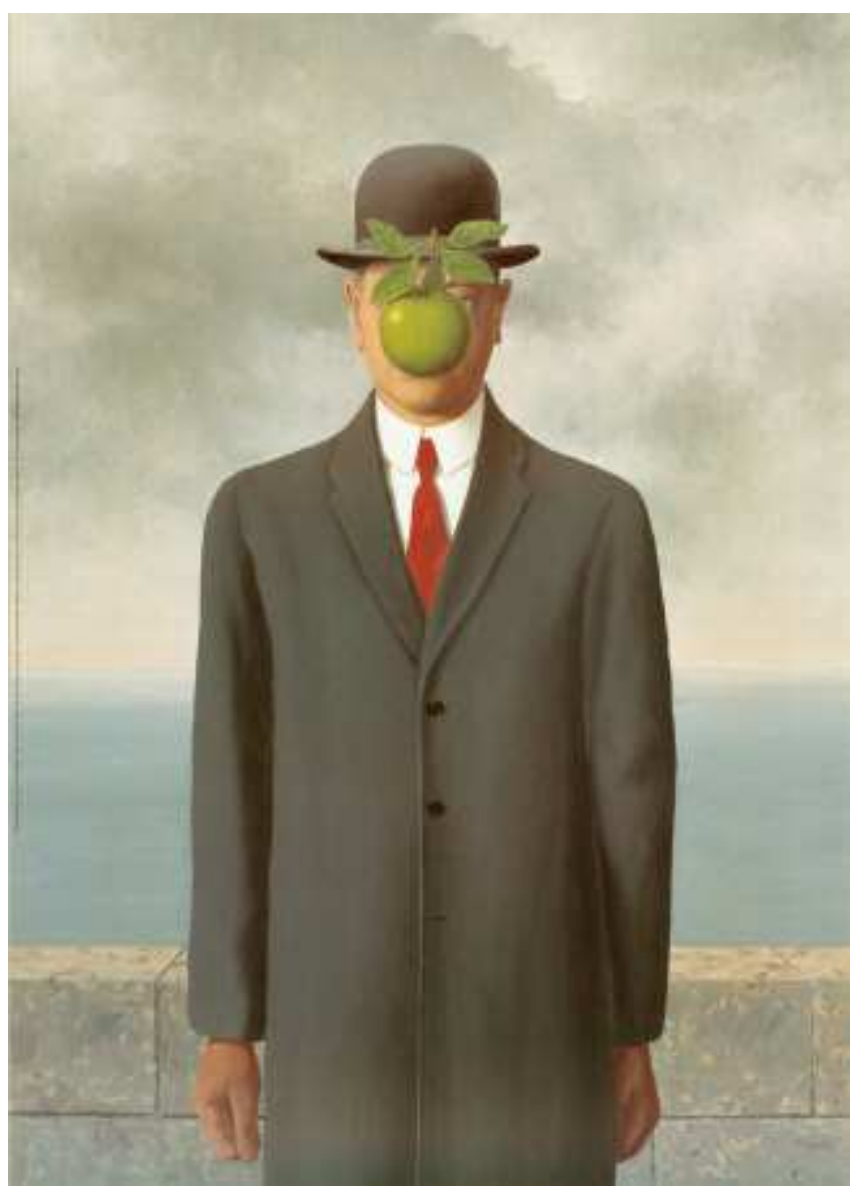

The Son of man. (1964) Rene Magritte

Ivair Carlos Castelan

São Paulo 
UNIVERSIDADE DE SÃO PAULO

FACULDADE DE FILOSOFIA, LETRAS E CIÊNCIAS HUMANAS

DEPARTAMENTO DE LETRAS MODERNAS

PROGRAMA DE PÓS-GRADUAÇÃO EM LITERATURA ITALIANA

\section{Zeno Cosini, uma identidade possível?}

Ivair Carlos Castelan

Dissertação apresentada à Faculdade de Filosofia, Letras e Ciências Humanas (FFLCH) da Universidade de São Paulo (USP), Campus de São Paulo, para obtenção do título de Mestre em Letras (Área de Concentração em Literatura Italiana).

Orientadora: Profa. Dra. Doris Nátia Cavallari

Aprovado em 26/09/2008

De acordo:

Profa. Dra. Doris Nátia Cavallari - Orientadora

São Paulo 
UNIVERSIDADE DE SÃO PAULO

FACULDADE DE FILOSOFIA, LETRAS E CIÊNCIAS HUMANAS

DEPARTAMENTO DE LETRAS MODERNAS

PROGRAMA DE PÓS-GRADUAÇÃO EM LITERATURA ITALIANA

\section{DISSERTAÇÃO PARA OBTENÇÃO DO GRAU DE MESTRE}

I

BANCA DE DEFESA

Titulares

Profa. Dra. Maria Celeste Tommasello Ramos

Profa. Dra. Vilma de Katinszky Barreto de Sousa

Profa. Dra. Doris Nátia Cavallari (orientadora)

\section{Suplentes}

Profa. Dra. Adriana Iozzi Klein

Prof. Dr. Júlio Cesar Pimentel Pinto Filho

Profa. Dra. Araguaia Solange de Souza Roque 


\section{DEDICATÓRIAS}

Dedico os resultados deste trabalho a todos que estiveram ao meu lado nesta apaixonante e intensa empreitada.

Dedico, em especial, ao Prof. Dr. Sérgio Mauro por introduzir-me no fantástico e intrigante universo da narrativa sveviana, e, sobretudo, pela marcante contribuição para meu crescimento intelectual e pessoal. 


\section{AGRADECIMENTOS}

Agradeço especialmente e dedico, de coração aberto, os resultados desta pesquisa:

$>$ a Deus, pelas batalhas vencidas, pelas conquistas, pela concretização de um sonho;

$>$ a toda minha família, pela confiança depositada;

$>$ à Profa. Dra. Doris Nátia Cavallari, pela paciente e confiante orientação e, acima de tudo, por acreditar em meu potencial e não desistir de mim;

$>$ à Profa. Fernanda Telles, Mestra primeira e especial, por enxergar em mim qualidades que eu não conseguia ver, pelos sábios ensinamentos, por lapidar-me intelectualmente;

$>$ ao Prof. Dr. Sérgio Mauro, eterno Mestre, pelos sábios e importantes ensinamentos, por ver em mim uma semente a ser plantada, e pela ajuda com as traduções;

$>$ ao Prof. Dr. Júlio Cesar Pimentel Pinto Filho, pela importante contribuição no direcionamento pontual de nosso estudo, pelas sábias sugestões e estímulo durante o Exame Geral de Qualificação, pelas indicações bibliográficas;

$>$ à Profa. Dra. Adriana Iozzi Klein, pelas sugestões pertinentes e estímulo durante o Exame Geral de Qualificação, pelo empréstimo de livros e sugestões bibliográficas;

$>$ à Profa. Dra. Vilma de Katinsky Barreto de Souza, pelo empréstimo de livros, pelo incentivo, por me fazer ver, em momentos de dúvidas, que estava no caminho certo;

$>$ à Profa. Dra. Maria Celeste Tommasello Ramos, pela atenção, incentivo e empréstimo de livros;

$>$ à Profa. Dra. Maria Gloria C. Mazzi, pelo estímulo e pelo empréstimo de livros;

$>$ ao Prof. Dr. Hilário Antonio Amaral, pela atenção, simpatia e empréstimo de livros;

$>$ às minhas especiais amigas, irmãs, Christiane Damien Codenhoto e Márcia Maria Sant' anna, pelo carinho, pelo intenso incentivo e constantes palavras de regozijo;

$>$ ao amigo, irmão, Claudemir F. Santos, por acolher-me em uma cidade "estranha" para mim, pelos ensinamentos, pela companhia nos momentos de tensão e alegria;

$>$ à grande amiga Lucilene Colodo, pelo incentivo, palavras motivadoras, por estar sempre presente, pela brilhante correção ortográfica deste sonho;

$>$ à amiga Suely Perucci, pelo exemplo de bondade e caráter, pelo apoio incondicional;

$>$ à amiga Maria Célia M. B. Fantin, pelo exemplo de perseverança, ética e bondade, pelo estímulo, pelas conversas nos momentos difíceis;

$>$ à médica e amiga Dra. Márcia Facco, pelo caráter, integridade e bondade, por acompanhar todo o meu trajeto, sempre confiante e segura de meu potencial;

$>$ a todos meus amigos especiais de São Carlos, Araraquara, São Paulo, Minas Gerais, Palhoça, Ribeirão Preto, Descalvado, São José do Rio Preto, Americana, Guarulhos, Rio Claro, Rio de Janeiro, Campinas e Garça por compreenderem e aceitarem minhas ausências, pelo carinho e presença fundamental nos momentos em que deles mais precisei;

$>$ a todos os amigos e funcionários da E.E. Prof. Arlindo Bittencourt, por me acolherem no início de minha árdua, mas gratificante caminhada como docente, pela força, crença no meu trabalho e torcida na concretização de um sonho;

$>$ aos meus ex-alunos, com carinho especial às turmas do $3^{\circ} \mathrm{A}$ e da $8^{\mathrm{a}} \mathrm{B}$, pela contribuição para meu crescimento não só profissional, mas principalmente pessoal;

$>$ a toda a equipe do Departamento de Letras Modernas, em especial Edite e Márcia, sempre atenciosas e dispostas a esclarecer todas minhas dúvidas.

$>$ à Biblioteca da FFLCH, pelo empréstimo de livros, e a todos os funcionários, pelo atendimento atencioso;

$>$ aos queridos amigos Talles Henrique Pereira e Fabiana Paganini, pelas palavras de coragem e tradução do abstract.

$>$ ao CNPq, pela concessão de bolsa de estudos, sem a qual talvez não teria conseguido concretizar este trabalho; 
Os grandes valores, quase sempre são compreendidos tardiamente.

Nietszche

Somos criaturas que contam histórias, produtos da história de nós mesmos.

Stephen Jay Gould 
CASTELAN, I.C. Zeno Cosini, uma identidade possível? Dissertação de Mestrado (Área de concentração: Literatura Italiana). Faculdade de Filosofia, Letras e Ciências Humanas, Universidade de São Paulo, São Paulo, 2008.

\section{RESUMO}

Publicado no ano de 1923, o romance A consciência de Zeno é importante por instaurar uma narrativa que traz em seu cerne a modernidade que rompe e transgride os cânones do modelo literário. O homem retratado por ela será marcado por frustrações, rodeado pelo vazio, atormentado pela angústia de viver. Assim nos é apresentado o narrador Zeno Cosini, cujo caráter é colocado em dúvida, já no prefácio, por seu suposto psicanalista e editor do texto. Enigmático e ambíguo, o senhor Cosini recorrerá, ao longo da enunciação de suas memórias, ao uso de várias máscaras para velar sua(s) identidade(s). Procurando o tempo todo ocultar-se, disfarçar-se, Zeno deixa em seu leitor um grande ponto de interrogação quanto à sua identidade e também o desafio de tentar responder "Quem é Zeno, afinal?". Assim, o objeto desta dissertação é investigar a(s) possível(eis) identidade(s) do narrador Zeno Cosini. Seguindo os meandros mais profundos de seu discurso, o presente trabalho procura desvelar, desmascarar o senhor Cosini que, por trás de suas máscaras, de seu discurso irônico e ambíguo, esconde uma identidade tão fragmentada e múltipla quanto a do homem de sua época. Não pretendemos estabelecer um único rótulo a este narrador, mesmo porque isso seria impossível. Nosso principal objetivo é rastrear seus passos, ouvir suas vozes dissonantes para, então, chegarmos a uma sentença acerca de sua constituição identitária, erigida através da narrativa.

Palavras-chave: Italo Svevo, A consciência de Zeno, identidade, literatura italiana, fragmentação, multiplicidade. 
CASTELAN, I.C. Zeno Cosini, a possible identity? Master's thesis (Italian Literature). Faculdade de Filosofia, Letras e Ciências Humanas, Universidade de São Paulo, São Paulo, 2008 .

\begin{abstract}
Published in 1923, the novel La coscienza di Zeno (Confessions of Zeno/Zeno's conscience) is important for building a narrative which brings in its core the modernity which disrupts and transgresses literary model's rules. The man described in it will be branded by frustrations, surrounded by nothingness, tormented by life's anguish. In that context the narrator - Zeno Cosini - is introduced, whose character is dubious since the preface by his supposedly text editor and psychoanalyst. Puzzling and ambiguous, mister Cosini calls upon the use of many masks to cover his identity throughout his memories. By trying to hide and cover himself all the time, Zeno leaves to his reader an intriguing question about his identity, as well as the challenge of trying to answer "Who is Zeno, anyway?". Therefore, this paper aims at investigating Zeno Cosini's possible identities. Following the deepest ways of his speech, the following paper seeks unveiling, uncovering Cosini that behind his masks, his ironic and ambiguous discourse hides such a fragmented and multiple identity as mankind of his age. It is not intended to label this writer even because it would be impossible. Our main goal is to trace his steps, hear his dissonant voices in order to reach a conclusion over his personality traits and identity structured through the narrative.
\end{abstract}

Keywords: Italo Svevo, Zeno's conscience, identity, italian literature, fragmentation, multiplicity. 


\section{LISTA DAS OBRAS PICTOGRÁFICAS}

\section{Página}

\begin{tabular}{|c|c|}
\hline $\begin{array}{l}\text { 1. The Son of man. (1964) Rene } \\
\text { Magritte }\end{array}$ & 1 \\
\hline $\begin{array}{l}\text { 2. Bond of Union. (1956) Maurits } \\
\text { Cornelis Escher }\end{array}$ & 24 \\
\hline $\begin{array}{l}\text { 3. The creation of man. (1508-1512) } \\
\text { Michelangelo Buonarroti }\end{array}$ & 51 \\
\hline $\begin{array}{l}\text { 4. Hand and Globe. (1935) Maurits } \\
\text { Cornelis Escher }\end{array}$ & 60 \\
\hline $\begin{array}{l}\text { 5. The Portrait of Giovanni Arnolfini } \\
\text { and his wife Giovanna Cenami. } \\
\text { (1434) Jan Van Eyck }\end{array}$ & 70 \\
\hline $\begin{array}{l}\text { 6. La Reproduction Interdite. (1937) } \\
\text { Rene Magritte }\end{array}$ & 88 \\
\hline $\begin{array}{l}\text { 7. Drawing Hands. (1948) Maurits } \\
\text { Cornelis Escher }\end{array}$ & 115 \\
\hline $\begin{array}{l}\text { 8. Skull with cigarette. Maurits } \\
\text { Cornelis Escher }\end{array}$ & 133 \\
\hline 9. Enigma without end. Salvador Dali & 145 \\
\hline
\end{tabular}




\section{SUMÁRIO}

Página

\begin{tabular}{|c|c|}
\hline Introdução & 11 \\
\hline Notas & 23 \\
\hline $\begin{array}{l}\text { Capítulo I } \\
\text { Italo Svevo, Solo Una Vita Non Può Bastare }\end{array}$ & 24 \\
\hline 1.1 Italo Svevo por ele mesmo & 25 \\
\hline 1.2 Italo Svevo: Solo Una Vita Non Può Bastare & 27 \\
\hline 1.3 Italo Svevo, homem múltiplo & 37 \\
\hline 1.4 Italo Svevo e Zeno Cosini, vidas paralelas? & 43 \\
\hline Notas & 48 \\
\hline $\begin{array}{l}\text { Capítulo II } \\
\text { A criação de Zeno Cosini }\end{array}$ & 51 \\
\hline 2.1 Zeno Cosini, herói de seu tempo? & 52 \\
\hline 2.2 Os olhares de Zeno, confiar ou não confiar : eis a questão! & 60 \\
\hline 2.3 Retrato de uma família burguesa, relações em jogo! & 70 \\
\hline 2.4 Quem tu és, Zeno Cosini? & 88 \\
\hline Notas & 107 \\
\hline $\begin{array}{l}\text { Capítulo III } \\
\text { Escrevo, logo existo }\end{array}$ & 115 \\
\hline 3.1 Escrita, maldição que salva? & 116 \\
\hline 3.2 Narrativa sveviana, sob os pilares da modernidade & 124 \\
\hline 3.3 Só sei que nada sei : a re-velação do discurso irônico & 133 \\
\hline Notas & 142 \\
\hline Considerações Finais & 145 \\
\hline Referências Bibliográficas & 155 \\
\hline
\end{tabular}




\section{INTRODUÇÃO}

Forse oggi l'obiettivo principale non è di scoprire che cosa siamo, ma piuttosto di rifiutare quello che siamo. Dobbiamo immaginare e costruire ciò che potremmo diventare.

M. Foucault

O solo apresentava-se pedregoso, com grande desnível, infértil e bastante hostil ao plantio. As condições climáticas, também, não eram favoráveis. A chuva custava a dar o ar de sua graça, enquanto o sol castigava, deixando cicatrizes na terra. Mesmo assim, o agricultor decidiu pelo plantio e, sobretudo, acreditou nele. Cada semente foi plantada com muito amor, dedicação e a confiança de que daria bons frutos.

Agricultor de palavras, o escritor Italo Svevo, nome de batismo Ettore Schmitz, também enfrentou condições adversas no "cultivo" de seus romances. Mesmo assim optou por escrevê-los, decidiu por acreditar em sua maior paixão, a literatura. Empenhou-se exaustivamente na colheita de frutos que insistiam em não amadurecer. Lutou com todas as suas forças na concretização de um sonho, o de ser escritor.

Nascido no ano de 1861, na cidade de Trieste, no seio de uma tradicional família burguesa, Svevo não chegou a depender da venda de seus romances para sobreviver, aliás, ele mesmo arcou com todas as despesas na publicação de seus livros. O trabalho no banco e, posteriormente, na empresa de verniz submarino do sogro sempre lhe propiciaram uma vida estável e confortável.

Sua história poderia ser a de mais um burguês que viveu no início do século XX, passando despercebida, não fosse o fervor e o talento peculiar que o instigou a retratar a vida e o homem. O gosto inato pela literatura e o desejo por escrever, quase uma obsessão, o perseguiram até o último minuto de sua vida. Através da escrita, ele buscou, acima de tudo conforme suas palavras - conhecer-se, entender-se, chegar a seu mais profundo e complexo eu. 
Sua arte foi negada e incompreendida, o reconhecimento custou por vir. Svevo carregou consigo esse dissabor por quase toda a sua existência. Chegou a declarar a "separação" da literatura, contudo o amor falou mais alto e, ainda que tenha vivido momentos difíceis, de tensão, sempre se deixou seduzir pela "tentação da escrita". Daí resultaram, além dos inúmeros contos e algumas peças de teatro, três romances: Uma vida, Senilidade e A consciência de Zeno, "filhos bastardos" que sentiram na pele o preconceito, por não se encaixarem nos moldes literários da época. Svevo empenhou-se no reconhecimento e, de certa forma, "aceitação" dos frutos de sua paixão pelas Letras.

Leitor voraz e, sobretudo, um exímio observador do mundo e da realidade que o circundava, o autor triestino conseguiu imprimir à vida fictícia de seus personagens traços realmente humanos. O homem pintado em sua obra distancia-se bastante do retrato de um indivíduo "virtuoso", repleto de qualidades. Seus personagens, totalmente destituídos das características de um super-homem, são fracos, incapazes, inaptos, vis, perseguidos pela angústia de viver e atormentados por crises existenciais.

Os três romances formam uma trilogia, na qual temos bem delineada e aprofundada a análise dos meandros do eu mais submerso da alma. A tríade, de acordo com Teresa de Lauretis, propõe

o mesmo conteúdo de experiência humana: amor não correspondido, dialética empregadopatrão, doença, morte, temas que se organizam em torno e em relação ao Herói, refletindo assim a unicidade de uma experiência individual vista através de lentes diversas e projetadas caso a caso diferentes ${ }^{1}$. (LAURETIS, 1976, p.12, tradução nossa)

As três obras investigam a mesma realidade humana. Realidade do homem em um mundo tão despedaçado e cindido quanto ele. Um mundo, já separado em uma pluralidade de outros mundos possíveis, cuja objetividade e exatidão dos contornos vêm substituídas por um

sujeito que filtra a realidade de modo prismático e tudo o que vier contado será o reflexo da consciência dos personagens "ineptos" e dos "homens sem qualidades", já impossibilitados de encerrar em uma única verdade a complexidade do real e a multiplicidade da vida que se oferece multifacetada e legível em mais níveis. Daqui o longo monólogo interior, o registro e transcrição 
dos fatos sem uma ordem cronológica, como se repentinamente tornasse difícil dar um senso unitário às coisas $^{2}$. (CALIFANO, 2000, p.86, tradução nossa).

Tudo nos é apresentado a partir de um eu, cheio de perguntas, que busca, muitas vezes inutilmente, saber e compreender o verdadeiro significado da vida, o sentido do destino de um homem que se vê e se sente dilacerado e dissociado, com grande necessidade de "gritar" aos quatro ventos suas frustrações, sua(s) história(s) de vida (DEBENEDETTI, 1987, p.517).

Svevo delineia,como se lê na antologia de Salinari, Ricci e Serri, um sujeito, vivente em uma sociedade burguesa, que acredita poder exercer, ilusoriamente, a própria liberdade de escolha, de poder satisfazer suas vontades. A esse problema da liberdade do homem liga-se toda a pesquisa narrativa de Svevo,

seja quando dirige a sua análise sobre os personagens para investigar seus desejos, desmascarar suas mentiras e os auto-enganos, coagindo o limiar da consciência, seja quando rompe a aparência tranqüilizadora da normalidade burguesa, trazendo à tona as hipocrisias, os condicionamentos e compromissos do viver social' ${ }^{3}$. (SALINARI; RICCI; SERRI, 1983, pp.1801 , tradução nossa)

Presos às aparências, às convenções sociais, demonstrando virtudes que não apresentam, os personagens svevianos procurarão se esconder atrás de máscaras, buscando ocultar o verdadeiro eu. Contudo, não conseguirão sustentar tais máscaras por muito tempo. $\mathrm{O}$ próprio comportamento inconstante, "desajustado", contraditório termina por denunciá-los, por desnudá-los, possibilitando que tracemos uma linha para entendermos melhor suas personalidades obsessivas e "doentias".

Assim, seu primeiro romance, Uma vida, publicado em 1892, narra a história de Alfonso Nitti, um enigmático bancário em busca de reconhecimento social e intelectual. Nitti é atormentado por uma personalidade incapaz de conciliar o mundo idealizado dos desejos e esperanças com as relações em uma sociedade dominada pelo interesse e pelo poder.

Já Senilidade, seu segundo romance, publicado em 1896, coloca em cena o elegante e culto Emilio Brentani que vê sua vida transformar-se completamente após descobrir-se 
enamorado pela bela Angiolina. Envolvida por mistérios, mentiras e traições, essa relação termina por concretizar-se em uma dolorosa, mas fundamental experiência de autoconhecimento para Brentani, que passa a enxergar com outros olhos o amor, a irmã, os amigos e também o mundo que o rodeia.

Publicado em 1923, seu terceiro e mais conhecido romance, A consciência de Zeno, objeto de nosso corpus de trabalho, conta a vida do burguês triestino, Zeno Cosini, que, na ânsia por curar-se de sua suposta "doença", recorre à psicanálise, como mais um meio para tornar-se "são". Como tratamento, o psicanalista, que nos é apresentado logo no prefácio, sugere ao paciente a escritura de suas memórias, como uma forma deste ver-se por inteiro.

Assim, Zeno começa a escrever os acontecimentos que julga mais importantes para, de certa forma, influenciar o tratamento e o médico, conforme seus interesses. Infância, adolescência, morte do pai, casamento com a mulher que ele "não" escolhera, sociedade comercial com o cunhado e o adultério, constituir-se-ão em alguns dos fios que Zeno usará para tecer seu discurso. Na teia de um discurso irônico, ambíguo e múltiplo de significações, nosso narrador oculta-se, mascara sua possível identidade.

Enigmático, fragmentado e múltiplo, Zeno é um, nenhum e cem mil ao mesmo tempo. Representando um homem que, na verdade, poderia ser qualquer um de nós, ele, através de suas memórias, descortinará os vícios e pseudovirtudes da sociedade burguesa da qual faz parte. Uma sociedade capitalista, preocupada em cultivar um belo jardim de aparências, sempre à procura de uma nova máscara para encobrir suas mazelas e essência.

A essência distorcida que Zeno nos apresenta de si mesmo e o seu caráter "metamorfoseante", despertaram em nós o desejo de tentar responder a algumas questões, entre elas: “Quem é Zeno?", "Será que podemos chegar a alguma hipótese acerca de sua possível identidade, uma vez que sua vida é narrada exclusivamente de seu ponto de vista?” A

\footnotetext{
${ }^{\mathrm{i}} \mathrm{O}$ termo metamorfoseante refere-se aqui à capacidade de Zeno de se adaptar às situações que a vida lhe apresenta, e não a uma radical transformação.
} 
partir de perguntas como essas, iniciamos nossa pesquisa, investigando as pistas deixadas por esse narrador ao longo de seu relato. Assim, adentramos no labirinto narrativo de Zeno, buscando no seu próprio discurso e também nas teorias de outros estudiosos deste romance, um possível fio de Ariadne.

O uso da metáfora do labirinto é importante para situarmos nosso leitor acerca do complexo emaranhado em que se constitui não só o discurso, mas principalmente o próprio Zeno. Tal uso justifica-se, ainda, na medida em que pretendemos apontar um possível caminho para chegarmos à(s) identidade(s) de Zeno.

Assim, o que nos propomos a estudar nesta dissertação é a temática e problemática que envolvem a identidade do narrador do romance A consciência de Zeno selecionado como corpus para este estudo.

Mundialmente conhecido e respeitado, Svevo é considerado, hoje, um dos maiores romancistas do século $\mathrm{XX}$, precursor de uma narrativa tida como de vanguarda, cujo tempo objetivo, cronológico, é substituído pelo tempo do "eu", da consciência inquieta de seus personagens. No Brasil, cada vez mais estudiosos, críticos e leitores vêem em sua obra um universo riquíssimo a ser descoberto e explorado. Dessa forma, ainda que façamos parte do programa de italiano, optamos por traduzir todas as citações originais da crítica para o português, inserindo ao final de cada capítulo o original em italiano. Ao optarmos por tal procedimento, pretendemos que nosso trabalho chegue não só aos apreciadores e conhecedores da língua italiana, mas também àquele leitor "curioso" que almeja aprofundarse no reino da narrativa sveviana, principalmente através do romance que constitui nosso corpus de estudo.

Apresentando uma narrativa riquíssima, aberta a visões e interpretações diversas, julgamos fundamental destacar que propomos mais uma leitura do romance, dentre as muitas já existentes e levadas em consideração para tecermos nosso discurso, procurando, contudo, 
realizar nossa leitura, essencialmente, a partir do tecido narrativo sveviano. Esclarecido esse ponto e a questão da tradução das notas, podemos partir em direção aos caminhos pelos quais enveredamos em busca das possíveis respostas às questões a que nos dispusemos investigar, tendo como foco central a questão da (não) identidade de Zeno.

A fim de iluminar as veredas percorridas, dividimos o presente trabalho em três partes. A primeira parte intitulada Italo Svevo, solo una vita non può bastare, traz fatos da vida do escritor triestino que, acreditamos, sejam importantes para o desenvolvimento do trabalho e que tem como protagonista maior não Svevo, mas a sua intensa e intrigante vida. Uma vida, como ele próprio ressaltou, que não parece bonita mas que foi tão enriquecida por afeições felizes que aceitaria vivê-la de novo (apud VICENTINI, 1984, p.8).

Apesar das frustrações, desencontros, decepções, em especial, as literárias, encontramos na história de Svevo um exemplo de perseverança, disciplina, paixão e entrega total a cada empreitada sonhada e realizada. Vivendo entre o tênue limite de cada ação, nosso escritor conseguiu cravar na História da Literatura um capítulo marcante por intermédio de um estilo, como bem ressaltou Aurora Bernardini, ainda hoje tão intrigante e desafiador para nós, com seu tipo especial de ironia e seus curiosos "procedimentos" (BERNARDINI, 1997, p.4).

De fato, Svevo contribuiu com a introdução de um novo e diferente estilo na narrativa do século XX. Liberta de alguns cânones do passado, esta narrativa traz um indivíduo destituído de virtudes e qualidades que parece, por vezes, paralisado diante de sua realidade, sem forças para lutar na cruel selva chamada vida. Enfim, um sujeito fragmentado, duplo, marginal, que vive entre dois "mundos", o imposto pela sociedade, no qual ele apenas sobrevive, sempre em busca de manter a(s) aparência(s) perante os outros, e aquele que, de fato, ele gostaria de viver e quereria vivê-lo. 
Tendo caminhado por estradas diferentes, e, de certa forma, contrastantes, nosso escritor, assim como o homem esboçado em suas escrituras, também carregará consigo um caráter múltiplo, procurando equilibrar-se em sua duplicidade, estabelecendo não um ponto para fixar-se, mas todos os (im-)possíveis. Dessa forma, finda a síntese da grandiosa e digna existência de Svevo, passaremos a um estudo de sua multiplicidade.

Cabe ressaltar que nosso principal intuito ao revisitar a biografia de Svevo, além de apresentar uma história digna de ser contada, será o de encontrar elementos que demonstrem que esse autor, assim como o homem "moderno" de sua época, é um ser múltiplo, fragmentado, à procura de respostas para seu vazio existencial e das quais vai em busca escrevendo.

Através da escrita, Zeno Cosini também buscará preencher suas lacunas, conhecer-se, entrar em contato com seu verdadeiro eu, almejando compreender quem ele é. A vida já não lhe satisfaz mais, por isso ele escreverá. Bom contador de histórias, o senhor Cosini fará de tudo para nos deixar duvidosos acerca da veracidade do que é enunciado por ele. Separar o joio do trigo de seu discurso é tarefa difícil, exige um trabalho meticuloso, uma vez que a certeza absoluta em classificar e separar suas verdades e mentiras apresentar-se-á, na maioria das vezes, como algo impossível e também desnecessário, já que as afirmações são sempre relativizadas, logo em seguida, pelo narrador.

Dessa forma, no segundo capítulo, nossa atenção estará totalmente direcionada ao protagonista-narrador de A consciência de Zeno. Nosso intuito aqui é iluminar os passos narrativos percorridos por Zeno, a fim de chegarmos à(s) sua(s) (im-)possível(is) identidade(s).

Alicerçado sobre características e qualidades, por assim dizer, "não-heróicas", fomos levados, principalmente, através do livro Em louvor de anti-heróis: figuras e temas da 
moderna literatura européia, de Victor Brombert (2001), a indagar se, de fato, Zeno constitui-se em um verdadeiro anti-herói de sua época.

Nesse texto, Brombert analisa os personagens que constituem a literatura dos séculos XIX e XX. Segundo ele, esses personagens "desajustados", "anti-heróicos", não se enquadram nos modelos de heróis existentes. Esses "anti-heróis", ou melhor, heróis modernos, estariam mais alinhados à época em que vivemos, bem como as nossas necessidades.

O crítico dedica um capítulo e um apêndice para mostrar a figura desse "anti-herói” na obra de Svevo. Assim, a escolha do presente texto, justifica-se como mais uma tentativa de entendermos a identidade (não-) heróica do protagonista em estudo, Zeno Cosini, que, como veremos, traz consigo as características do herói moderno. À esteira de Brombert, Teresa de Lauretis (1976), em La sintassi del desiderio: Struttura e forme del romanzo sveviano, também analisa Zeno como um verdadeiro herói de seu tempo, um herói com características verdadeiramente humanas, um herói mais próximo da realidade vivida.

Na seqüência, a fim de entendermos melhor a maneira como Zeno apreende o mundo que o rodeia, dedicamo-nos a um breve estudo de seus "olhares". Uma vez que a narrativa apresenta-se em primeira pessoa, não teremos alternativas, a não ser entrar em contato com a vida de Zeno através de seu(s) olhar(es), procurando distinguir sua(s) voz(es). Assim, buscamos compreender melhor a caracterização, os meandros da narrativa em primeira pessoa. Para tanto, alicerçamos nossa fundamentação teórica, principalmente, através dos estudos de Jean Pouillon (1974), Oscar Tacca (1978), Alfredo Leme Coelho de Carvalho (1981) e Vitor Manuel de Aguiar e Silva (1983), não excluindo, contudo, os pressupostos de outros teóricos que discorrem acerca do foco narrativo no presente romance.

Findo o sucinto estudo sobre o foco narrativo do romance, debruçamo-nos sobre as relações entre Zeno e seus familiares. Tal escolha deve-se, também, como mais um meio de 
chegarmos a uma possível identidade de Zeno. Permeada por interesses e conveniências sociais, as relações familiares contidas no romance serão importantes por colocar em cena o retrato de uma sociedade burguesa, sempre voltada às aparências. Através de elementos do próprio romance e também da posição defendida por alguns críticos, procuraremos mostrar a importância dessas relações na constituição do personagem Zeno que terminará por consagrar-se no seio da família como o verdadeiro herói, reforçando assim, a premissa já discorrida no início do mesmo capítulo.

Nossa segunda jornada será encerrada com a discussão acerca dos elementos que contribuem no processo de formação de uma identidade. Para tanto, buscamos respaldo, essencialmente, na teoria do filósofo italiano Alberto Melucci em $O$ jogo do eu. A discussão sobre identidade em face de um eu múltiplo ocupa, sem dúvida, espaço central e mais provocativo nessa obra, no qual Melucci traz à tona a dificuldade cada vez maior de se responder com segurança à pergunta: “Quem sou eu?”.

Segundo o filósofo italiano, vivemos em um mundo repleto de questionamentos sem respostas. Imbuído por inúmeras perguntas, nosso protagonista buscará através da escrita, as possíveis réplicas que possam dar-lhe sustentação no processo de seu autoconhecimento. Zeno construirá sua identidade à medida que enunciar suas memórias, buscará conhecer-se através da narrativa.

Nesse processo de autoconhecimento, o vício pelo fumo terá papel fundamental, uma vez que Zeno decide escrever a fim de curar-se da obsessão pelo cigarro. Assim, podemos dizer que, sem o eterno propósito de fumar o último cigarro, Zeno não teria vida e, conseqüentemente, não conheceríamos suas memórias.

É importante ressaltar que a doença, na obra, é desnudada de seu caráter negatório, anulador, adquirindo teor criativo, ligando-se a um pólo que normalmente não é o seu, o 
construtivo que permitirá a nosso protagonista significar-se. Sua moléstia dar-lhe-á a oportunidade de analisar-se, conhecer-se e constituir um novo capítulo em sua existência.

A doença pode ser lida, ainda, conforme ressaltado no estudo de Miorin, como a metáfora chave da incapacidade de se relacionar dentro de uma estrutura centrada ou privilegiada, assim como a saúde torna-se um efeito secundário do bem-estar sócioeconômico (MIORIN, 2006, p.75). Para Salinari, Ricci e Serri, o personagem "inepto" sveviano, ameaçado em sua identidade e em sua liberdade individual, é aquele que não aceita viver seguindo as regras do conformismo social (SALINARI; RICCI; SERRI, 1983, pp. 1867). Nesse contexto, a doença de Zeno vem reforçar a premissa de sua dificuldade em aceitar as normas sociais impostas.

Procurando renegar sua "doença", mas ao mesmo tempo experimentando-a e, sobretudo, sentindo-a febrilmente, latente em cada nível de seu ser, Zeno chegará à consciência de que, sem ela, não estaria a analisar-se, a procurar entender-se, conhecer-se. Através dela, ele inicia uma das mais temidas e tortuosas viagens a que um homem pode empreender, a do conhecimento do próprio eu.

Sabermos quem somos pode parecer simples e fácil na superficialidade, contudo, nas profundezas de nossa alma a história é outra. Voltar-se para dentro, buscando nossos gostos, anseios e desejos proibidos pode ser uma aventura intrigante e assustadora, uma vez que nossa essência pode estar em desacordo com o mundo de aparências que criamos para podermos nos aceitar e sermos aceitos na sociedade em que vivemos.

Zeno, viajante de si mesmo, seguindo o único trajeto possível, o da narrativa, o da escrita, entrará em contato com seus vários “eus”, evidenciando sua fragmentação que, na verdade, é a fragmentação de todo homem. Não somos seres homogêneos em nossa essência, dentro de nós, como bem frisou Alfredo Bosi, coexistem diversas almas: a social, a profissional, a intelectual, a doméstica, tantas quantas exigir a variedade de interlocutores 
(BOSI, 1988, p.190). Cabe a nós escolhermos de qual delas faremos uso em determinado momento ou situação. A partir disso, podemos inferir a impossibilidade de aprisionarmos Zeno em um único eu. Sua identidade, entendida a partir da narrativa, abrigará em si o heterogêneo, o múltiplo. Sua beleza e grandeza residem em sua luta pelo direito de viver todas as suas identidades (não) possíveis.

Assim, encerrar-se-á a segunda jornada de nossa caminhada, cujo intuito principal será o de apreender a(s) possível(is) identidade(s) de que Zeno faz uso. Nesse processo, sua “doença" e o ato de escrever serão de suma importância para (re-)velá-lo. Partindo do cigarro e da escrita, atentos a seu discurso e, ainda, alicerçados sobre estudos que discorram sobre identidade, delinearemos os contornos imprecisos e borrados de um eu que "quer ser diferente", que busca, de certa forma, preservar sua (não) identidade, ao relativizar os episódios narrados de sua vida.

$\mathrm{Na}$ terceira e última etapa deste trabalho, discorreremos brevemente sobre a narrativa sveviana, em especial, a de Zeno que se constitui em uma autobiografia em forma de memórias, da qual procuraremos apontar a ambigüidade e ironia discursivas, destacando o ato de escrever, como a possível salvação deste narrador "atormentado".

Mostraremos ainda que a narrativa de Svevo apresenta certo caráter transgressor, inovador e moderno para sua época. Através dos complexos estudos de Debenedetti (1987), veremos que essa narrativa rompe com o tecido discursivo do passado, superando tendências explicativas. Assim como o homem pintado por ela, será pontuada por interrogações e dúvidas. Dessa forma, tal estudo vem corroborar com a nossa premissa de que o homem moderno, representado por Zeno Cosini, já não sabe quem é e percorrerá toda sua existência questionando-se, procurando respostas para si próprio.

Nascida sobre a insígnia da ambigüidade, essa narrativa encontrará na ironia sua expressão maior. Assim, na seqüência, procuraremos entender um pouco mais do 
funcionamento da ironia em si e no romance. Os subsídios para tanto serão buscados, em especial, na teoria de Beth Brait (1996), em Ironia em perspectiva polifônica, e de Linda Hutcheon (2000), em Teoria e política da ironia. Com este estudo, pretendemos encerrar nossa terceira e última jornada.

A partir das veredas esmiuçadas acima, pretendemos buscar e investigar dados que esclareçam algo que permeia todo o romance, como já foi ressaltado, mas não aprofundado por Luciana Martinelli, ou seja, a problemática em torno da identidade de Zeno Cosini (MARTINELLI, 1988, p.104). Veremos que a chave para entendermos sua constituição identitária, que abrigará não um, mas vários "eus", encontra-se intrinsecamente ligada ao tecido narrativo de suas memórias. 


\section{Notas}

\footnotetext{
${ }^{1}$ lo stesso contenuto di esperienza umana: amore non corrisposto, dialettica servo-padrone, malattia, morte, temi che si organizzano attorno all'Eroe e in relazione ad esso, riflettendo così l'unicità di una singola esperienza vista attraverso lenti diverse e proiettata su schermi di volta in volta diversi.

${ }^{2}$ soggetto che filtra la realtà in modo prismatico e tutto ciò che verrà raccontato sarà il riflesso della coscienza di personaggi "inetti" e di "uomini senza qualità", perché impossibilitati a racchiudere in un'unica verità la complessità del reale e la molteplicità della vita che si offre sfaccettata e leggibile a più livelli. Di qui il lungo monologo interiore, la registrazione e trascrizione dei fatti senza un ordine cronologico, come se fosse diventato improvvisamente difficile dare un senso unitario alle cose.

${ }^{3}$ sia quando rivolge la sua analisi sui personaggi per scandagliarne i desideri, smascherarne le finzioni e gli autoinganni forzando la soglia della coscienza, sia quando incrina la crosta rassicurante della normalità borghese portando alla luce le ipocrisie, i condizionamenti e i compromessi del vivere sociale.
} 
ITALO SVEVO, SOLO UNA VITA NON PUÒ BASTARE

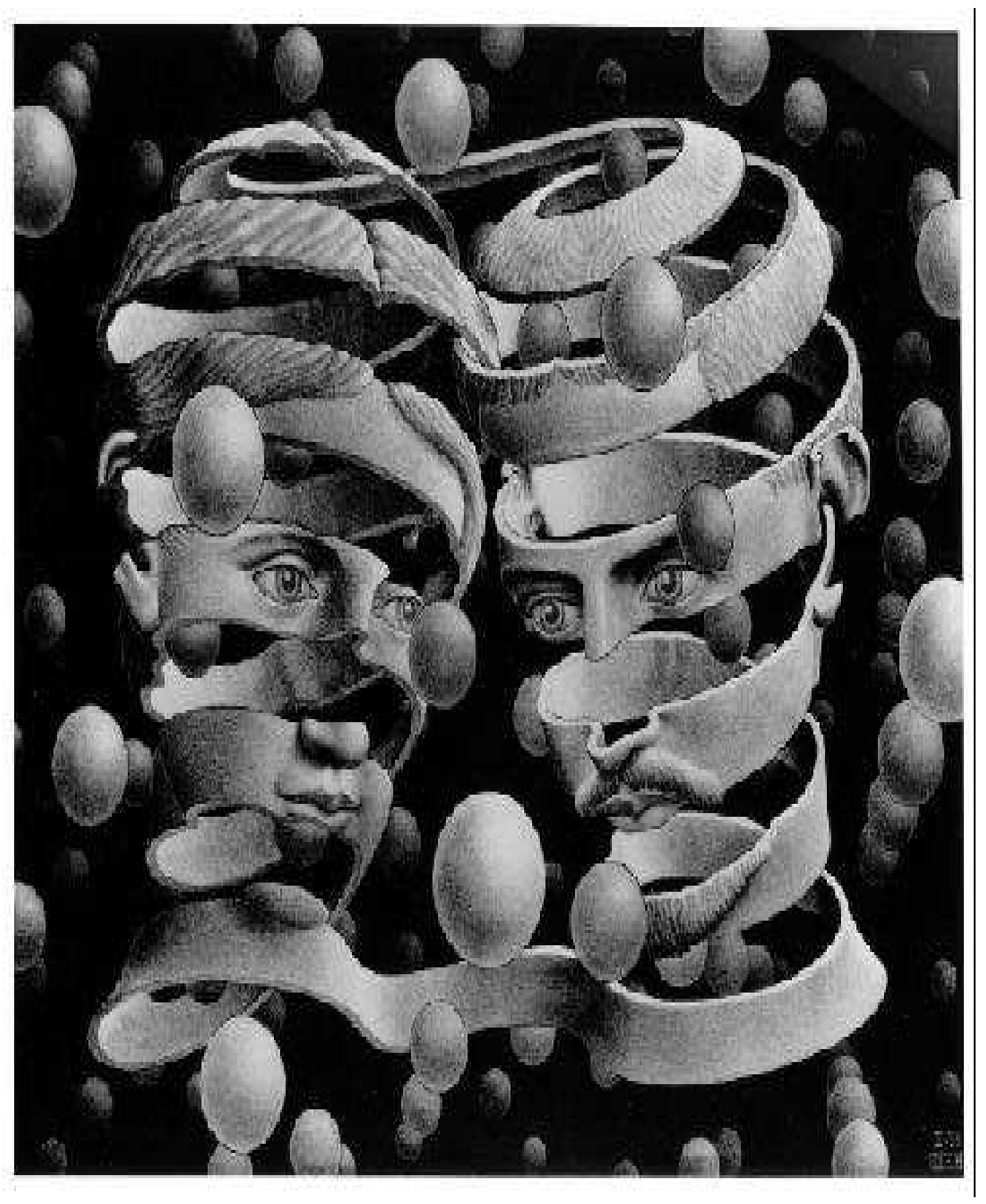

Bond of Union. (1956) Maurits Cornelis Escher 


\subsection{ITALO SVEVO POR ELE MESMO}

Não importa o quanto vivemos, e sim como vivemos.

Bailey

Eis, em poucas palavras, minha biografia.

Nasci em Trieste no ano de 1861. Meu avô alemão era funcionário do Estado em Treviso; minha avó, minha mãe, italianas. Com doze anos fui para Alemanha estudar numa escola comercial, onde estudei menos do que ofereciam. Naqueles anos, contudo, apaixonei-me pela literatura alemã. Com dezessete anos entrei para a Escola Comercial Superior Revoltella de Trieste, onde reencontrei minha italianidade. Com dezenove anos, num banco; e em Una vita a parte dedicada ao Banco e à Biblioteca Cívica é realmente autobiográfica.

Com trinta e seis anos tive a sorte de entrar numa empresa industrial, na qual tomo parte ainda hoje. Até a deflagração da guerra trabalhei muito, principalmente dirigindo operários em Trieste, Murano (Veneza) e Londres. Com trinta publiquei Una vita e com trinta e sete Senilità. Resolvi depois renunciar à literatura, que evidentemente atenuava minha capacidade comercial, e dediquei as poucas horas livres ao violino, de forma a afastar de mim o sonho literário. A guerra fez-me perder os negócios e foi provavelmente por causa da inatividade prolongada que, em 1919, comecei a escrever La Coscienza di Zeno, que publiquei em 1923.

Isso é tudo. Uma vida que não parece bonita mas que foi tão enriquecida por afeições felizes que aceitaria vivê-la de novo. (apud VICENTINI, 1984, p.8)

Assim, Italo Svevo apresentou-se ao público francês. Escrita em 1927, um ano antes de sua morte, essa sucinta autobiografia veio acompanhada pela publicação de seu maior romance, A consciência de Zeno, no país de Zola. Iniciava-se, naquele momento, o reconhecimento internacional de um escritor que viveu no esquecimento do anonimato por longos anos.

Nas poucas palavras escritas pelo escritor triestino sobre sua história, dois pontos merecem destaque. $\mathrm{O}$ primeiro diz respeito à sua dupla formação, a italiana e a alemã. $\mathrm{O}$ duplo sempre esteve presente na vida de Svevo: as culturas italiana e alemã, o fato de ser um homem de negócios e ao mesmo tempo escritor, a dedicação contemporânea à literatura e à filosofia, para citar apenas alguns pares. Esse caráter duplo, cindido, também aparecerá, de certo modo, em sua obra. 
O segundo ponto faz referência à posição que Italo Svevo atribuiu à literatura. Esta, de acordo com suas palavras, ocupou um plano secundário em sua vida, sobretudo quando ele afirma: resolvi depois renunciar à literatura que evidentemente atenuava minha capacidade comercial, e dediquei as poucas horas livres ao violino, de forma a afastar de mim o sonho literário (apud VICENTINI, 1984, p.8).

A fim de fugir desse "sonho literário", Svevo buscou refúgio, primeiramente, em sua atividade comercial e depois no violino, conforme ele mesmo explicita. Entretanto, sabemos que nosso escritor não conseguiu escapar da "tentação" da escrita. Sua paixão pelas letras foi muito maior. Ainda que seu casamento com a literatura enfrentasse turbulências, desentendimentos, separações, os "cônjuges" terminaram por se entender, constituindo uma história com final feliz, ou melhor, original. Diante de sua grandeza e originalidade, torna-se impossível construir sua biografia com poucas palavras. Sua história é digna e merecedora de um debruçar-se maior de nossa parte. Passemos, então, a um panorama, ainda que sucinto, da vida deste grande literato. 


\subsection{ITALO SVEVO: SOLO UNA VITA NON PUÒ BASTARE!}

Nada no mundo se fez de grande sem paixão.

Friedrich Hegel

Ettore Schmitz, ou Hector Aaron Schmitz, nome de batismo de Italo Svevo (pseudônimo adotado junto à sua atividade literária), nasceu em Trieste em 19 de dezembro de 1861. Filho de Francesco Schmitz e Allegra Moravia, ambos de origem judia. Quinto de oito filhos do casal, o escritor triestino teve uma infância felicíssima, conforme suas próprias palavras registradas em Profilo autobiografico, escrito por ele em terceira pessoa (CLAAR, 1986, p.15). Em Vita di mio marito, sua esposa, Livia Veneziani, descreveu o início de sua existência com ternura, quase mitificando, de acordo com Micaela Pretolani Claar, aqueles anos (CLAAR, 1986, p.15) que eternizaram cenas de uma família harmoniosa. Vejamos:

Os quatro meninos e as quatro meninas (Paola, Natalia, Noemi, Adolfo, Ettore, Elio, Ortensia, Ottavio) inteligentes e cheios de vitalidade, cresciam em grande companheirismo. A mãe atenuava, com a sua doçura, a severidade do pai. Chamava-se Allegra e emitia algo desse nome, clareando a atmosfera ao seu redor. Sempre se punha na janela para olhar os filhos saírem todos juntos. Eram como os tubos do órgão. Formavam uma fila, mas freqüentemente faltava um: Ettore ficava por último, o distraído que perdia tudo /.../ . A pequena sociedade inteligente, rica de iniciativa, inventava rápida e continuamente novos divertimentos.

Criaram até um jornal escrito a mão em que cada um dos irmãos redigia uma parte. Todos os acontecimentos domésticos vinham anotados e sempre comentados com muito humorismo. No jornal notava-se o dedinho de Adolfo, que era de temperamento alegre e brincalhão. A única cópia amarelada conservada entre as recordações da família traz o hermético título Adotajejojade. A estranha palavra era formada pelas iniciais dos diminutivos familiares ${ }^{1}$. (CLAAR, 1986, pp. 15-16, tradução nossa)

Ainda criança, o pequeno Ettore, foi mandado, em companhia dos irmãos Elio, seu grande admirador e primeiro biógrafo, e Adolfo, ao colégio de Segnitz, vizinho a Würzburg, na Baviera, onde iniciou os estudos voltados às atividades comerciais e aprendeu a língua alemã, importante para as transações comerciais. Fascinado pelo universo do saber e do 
conhecimento, nosso futuro escritor criou, juntamente com alguns colegas da escola, uma espécie de círculo intelectual. Nessa época, escreveu uma monografia filosófica em alemão, na qual se opunha ao estudo de um condiscípulo seu. Nesse colégio, Ettore entrou em contato, ainda, com grandes clássicos alemães, entre eles Goethe e Schopenhauer, cujas ideologias influenciariam na tessitura de sua obra. Também fizeram parte de sua leitura os romancistas franceses, em especial Balzac e Flaubert, e o escritor russo Turgenev.

Em 1878, aos dezessete anos, tendo concluído os estudos na Alemanha, retornou à sua Trieste onde freqüentou por dois anos, sem muita paixão, o Instituto Superior de Comércio Pasquale Revoltella. Dois anos mais tarde, em função da falência dos negócios do pai, Ettore foi obrigado a procurar trabalho, empregando-se, no dia 27 de setembro de 1880, na filial triestina do Banco Union de Viena, onde permaneceu por dezoito anos. Insatisfeito com sua ocupação, ele encontrou na literatura um refúgio, uma forma de entrar em contato com seu eu mais profundo. Assim, na Biblioteca Municipal de Trieste, ele empregava todo o tempo livre na leitura dos clássicos de seu país, bem como dos grandes escritores franceses do século XIX.

O amor pelo universo literário era inato a Ettore que sonhava em tornar-se um escritor renomado, contudo, além da imposição do pai e das condições de vida para que ele se tornasse um homem de negócios, havia a questão lingüística. Os anos de estudo na Baviera, o uso corrente do alemão nas transações comerciais e a comunicação entre amigos e familiares através do dialeto triestino constituíam-se em uma fronteira no uso do italiano standard. Tal fato foi relatado por sua esposa em Vita di mio marito. Vejamos:

Ettore, cada vez mais atraído pela literatura, sofria por não dominar perfeitamente a língua, seja pela instrução tida em uma escola estrangeira, seja pelo hábito contínuo do dialeto, também usado pelas classes cultas triestinas, no falar familiar. E cultivava secretamente um sonho: o de convencer o pai a mandá-lo por um ano para Florença, para apreender a língua através das fontes vivas. Sabia, entretanto que isto não passava de um lindo sonho e que o seu destino era tornar-se comerciante como o irmão Adolfo. Assim havia sido estabelecido pelo pai. A literatura era algo muito distante da mentalidade do velho Schmitz e Ettore, apesar de sua ardente vocação como escritor, não tinha coragem de opor-se à vontade do pai que governava com firme autoridade a família, cuja prosperidade vinha declinando ${ }^{2}$. (CLAAR, 1986, p.17, tradução nossa) 
De acordo com Maria Celeste Tommasello Ramos, naquela época, os dialetos de cada cidade eram muito fortes, sobrepondo-se, na maior parte das vezes, à língua italiana standard (baseada no dialeto florentino) (RAMOS, 2001, p.23). Fadado ao dialeto como língua materna, Ettore esforçou-se durante toda a vida para dominar a língua nacional e, ainda que tenha adquirido maior segurança com o decorrer do tempo, esse "problema" fez-se sempre presente entre suas angústias.

Apesar de todos esses obstáculos, a paixão pelas letras e o desejo de se tornar escritor levou Ettore a atuar, em 1880, como colaborador do jornal L'indipendente escrevendo críticas literárias e musicais. Em dez anos de colaboração, nosso escritor escreveu um total de vinte e sete artigos e dois contos, Una lotta e L'assassinio di Via Belpoggio.

O ano de 1880 foi de suma importância à vida literária do jovem Schmitz. Em fevereiro, ele começou a rascunhar a comédia Ariosto governatore; em março, Il primo amore; em julho, Le Roi est mort; vive lê Roi!, seguida da peça I due poeti. No ano seguinte, iniciou o conto Difetto moderno e escreveu La storia dei miei lavori. Em março do mesmo ano, escreveu o conto I tre caratteri, posteriormente chamado de La gente superiore. Essas atividades foram acompanhadas pela entediante rotina como empregado no banco e a "difícil" vida em família, afetada pela falência da empresa do pai.

O ano de 1886 veio acompanhado por uma grande perda na vida de Ettore. A morte, aos vinte três anos, de seu querido e predileto irmão Elio, causou-lhe muita dor, deixando grandes feridas, difíceis de serem esquecidas e cicatrizadas. Esse trágico acontecimento foi seguido, em um curto espaço de tempo, por outras desgraças na família, envolvendo suas irmãs: Noemi e Ortensia, pouco depois, também morreram; o casamento de Paola fracassou e os dois filhos de Natalia nasceram surdos-mudos. 
Depois dessa tempestade de tragédias familiares, sua vida encontrou um pouco de calmaria. Em 1887, deu início à redação de seu primeiro romance, provisoriamente intitulado Un inetto. Este publicado em 1892, pela editora Vram, a expensas próprias, sob o título de Uma Vida, já assinado com o pseudônimo Italo Svevo, narra os infortúnios do bancário Alfonso Nitti que vive em conflito com os valores de um mundo que privilegia a conquista e a afirmação do poder. A respeito da obra, houve apenas uma observação de Domenico Oliva, chamando atenção, nas páginas do jornal Corriere della Sera, sobre a novidade literária. Isso não foi suficiente e o romance passou despercebido. Ao lado dessa indiferença e silêncio da crítica e público, deu-se, ainda, no mesmo ano, a morte de seu pai.

Ocasionalmente, no funeral do patriarca da família, ele, depois de um longo período, reencontrou a prima Livia Veneziani, filha de um industrial católico, proprietário de uma fábrica de verniz submarino. Com a morte da mãe em 1895, nosso escritor aproximou-se mais da prima, descobrindo-se enamorado por ela. Seu amor foi declarado e firmado em uma página, segundo Micaela Pretolani Claar, do seu Diário de 1896, com a seguinte frase Livia nasceu para Schmitz (CLAAR, 1986, p.22). Em dezembro do mesmo ano (1895), ficou noivo da prima, treze anos mais jovem, casando-se no mês de julho do ano seguinte, civilmente. Pouco tempo depois, após abjurar a religião hebraica, o que o fez sentir-se "estranho" à comunidade hebraica triestina, ocorreu o casamento seguindo o ritual católico. Svevo passou a fazer parte, assim, de uma sólida e rica família burguesa.

Em 1897, deu-se o nascimento de sua primeira e única filha, Letizia. Nessa época, Svevo mantinha três empregos: o banco, o trabalho noturno no jornal Piccolo, e a docência no Instituto Revoltella.

Entre 1896 e 1897, dedicou-se à escrita de um novo romance, Senilidade, publicado inicialmente em capítulos no jornal L'Indipendente. Seu segundo romance foi publicado em um único volume no ano de 1898, pela Editora Vram, novamente a expensas do escritor. A 
obra coloca em cena o conflito do burguês, Emilio Brentani, que se descobre enamorado pela operária, Angiolina. Novamente, o livro não foi bem acolhido. Segundo Maria Celeste Tommasello Ramos, houve somente um comentário negativo da crítica local e descaso completo da crítica nacional (RAMOS, 2001, p.26). Tal fato foi destacado por Svevo em seu Profilo autobiografico, vejamos:

O romance não obteve nenhum sucesso na Itália. Nenhum jornal italiano ocupou-se disso, com exceção do "Indipendente" que publicou uma nota nos próprios suplementos. Nem mesmo o jornal mais importante de Trieste (isto é, o "Piccolo della Sera") comentou, uma vez que o romance havia sido publicado nos suplementos do jornal concorrente ${ }^{3}$. (CLAAR, 1986, p.26, tradução nossa)

É importante ressaltarmos aqui que o romance, segundo Claar, foi lido pelos triestinos, movidos por certa curiosidade provinciana e ânsia de encontrar nos protagonistas quatro personagens conhecidos no cenário burguês de Trieste: Emilio Brentani seria, na verdade, o empregado Ettore Schimtz; Angiolina, a bela Giuseppina Zergol, uma paixão que Svevo tivera; o escultor Bali, seu amigo e pintor Umberto Veruda; e Amália, a irmã do jornalista Cesare Rossi (CLAAR, 1986, p.26). Entretanto, toda essa curiosidade e furor não foram suficientes para o reconhecimento da obra.

O insucesso do romance e, de certa forma, o casamento, distanciaram-no da literatura. Em 1899, ele abandonou os empregos que tinha e foi trabalhar na empresa do sogro, dedicando-se à sua nova função com garra e fervor. "Artista negado" só lhe restou fazer o uso das vestes de um verdadeiro homem de negócios, um autêntico representante da burguesia de sua época. Era impossível, pelo menos nesse momento de sua vida, conciliar as duas funções, comerciante e escritor. Além do mais, não podemos nos esquecer de que, de acordo com Paolo Puppa, na sociedade burguesa do final do século XIX, era mal-visto ser burguês e artista ao mesmo tempo (PUPPA, 1995, pp.33-4).

A escrita, nesse período, foi colocada em segundo plano; em um diário secreto ele anotou que eliminaria definitivamente da sua vida algo tão ridículo e prejudicial como a 
literatura (FALQUI, 1970, p.18). O trabalho, na fábrica de vernizes submarinos do sogro, ocupava todo seu tempo e, aparentemente, usurpava-lhe todo o estímulo para escrever. Entretanto, mais uma vez a sua paixão pelas letras falou mais alto e, em 1903, de acordo Mario Lunetta, ele terminou a comédia Un marito (LUNETTA, 1976, p.10). O ano seguinte viria marcado pela morte de seu amigo, o pintor Umberto Veruda, que lhe havia inspirado na criação do personagem Balli, de Senilidade.

A empresa do sogro progredia cada vez mais. Com a ampliação das atividades desta no exterior, o autor foi obrigado a iniciar suas viagens pela Europa, mais especificamente pela França e, sobretudo, pela Inglaterra, país muito admirado por Svevo, por sua cultura, o que o levou a aprimorar o conhecimento da língua inglesa. Para tanto, iniciou as aulas de inglês em sua Trieste, na Berlitz, School, com um jovem professor irlandês chamado James Joyce. Desse encontro, ocorrido no ano de 1906, nasceu uma bela amizade, que reacendeu, ainda mais, em Svevo a paixão pela literatura.

Apesar da diferença de idade, Svevo contava com seus 45 anos e Joyce apenas 23, havia grandes afinidades entre eles. A paixão literária parecia intrínseca a ambos. O jovem Joyce, que, posteriormente, ficaria conhecido como um dos maiores escritores da língua inglesa, também havia escrito algumas poesias e alguns capítulos de Dubliners. O escritor irlandês pediu para que Svevo lesse seus manuscritos. Isso encorajou o triestino a mostrar-lhe seus dois primeiros romances. A esse propósito, sua esposa escreveu:

O irlandês, que nunca havia falado a ninguém dos seus trabalhos literários, levou rapidamente os seus manuscritos a Villa Veneziani. Tratava-se das poesias de "Chamber music" e alguns capítulos de Dubliners. Levado por estes entusiasmos literários, um dia Svevo apresenta ao jovem os seus dois velhos romances, como se quisesse dizer: eu também fui um escritor. Joyce os leu rapidamente e durante a aula seguinte declarou que, de acordo com sua opinião, Svevo havia sido injustamente negligenciado. Acrescentando, com fervor, que algumas páginas de Senilidade não poderiam ter sido melhor escritas, nem mesmo pelos grandes mestres do romance francês. Diante das palavras inesperadas, um bálsamo invadiu o coração de Ettore. Ele olhava o irlandês com grandes olhos de encantamento, satisfeito e pasmo. Nunca imaginou ouvir tantos elogios aos seus romances esquecidos ${ }^{4}$. (CLAAR, 1986, p.29, tradução nossa) 
Dessa amizade com Joyce, Svevo reencontrou forças e coragem para retornar ao cenário literário. Nas aulas de inglês, o único assunto entre os dois era literatura; tratavam de problemas e projetos literários. Nessa ocasião, Italo revelou-lhe a vontade de contar uma história de amor entre um velho e uma jovem, primeiro "esboço" do conto Novella del Buon Vecchio e della Bella Fanciulla. Joyce, por sua vez, expunha seus problemas literários e procurava inspiração no amigo para a criação do personagem Bloom de Ulisses (CLAAR, 1986, p.29).

Por volta do ano de 1908, Svevo entrou em contato com a psicanálise através da leitura de alguns textos de Freud. Em 1910, teve a oportunidade de constatar, de perto, os resultados obtidos com a aplicação da teoria freudiana, através de um amigo que buscara a psicanálise em Viena e retornara tão doente quanto antes. O aprofundamento na teoria psicanalítica ocorreu, entretanto, por intermédio do cunhado Bruno, extremamente abalado psicologicamente, que buscara cura em um tratamento pessoal com Freud, não obtendo resultados satisfatórios.

Svevo acreditava que a psicanálise era mais útil aos romancistas do que aos médicos, porém não deixou de reconhecer o valor e importância da teoria freudiana. Em 1927, ao responder à carta de um jovem perturbado psicologicamente, chamado Jahier, que lhe pedia informações sobre a eficácia da psicanálise no tratamento dos males interiores, Svevo expôs sua posição em relação ao "pai da psicanálise":

Grande homem o nosso Freud, contudo mais para os romancistas do que para os doentes. Um parente meu saiu do tratamento que durou vários anos quase aniquilado. Foi por meio dele que eu, há cerca de quinze anos, conheci a obra de Freud. E conheci alguns dos médicos a seu redor $^{5}$. (CLAAR, 1986, p.31, tradução nossa)

A psicanálise serviu de mote a seu terceiro romance, A consciência de Zeno, publicado em 1923, no qual o protagonista recorrerá à terapia para curar-se, contudo a cura não se concretizará. Svevo, ao introduzir a psicanálise nesse romance, de certa forma, a "reinventou", atribuindo-lhe uma nova roupagem. A teoria freudiana, assim, foi usada por ele 
não como um instrumento de cura, mas como um meio, de acordo com Claar, de compreender e definir a doença congênita da vida ${ }^{6}$ (CLAAR, 1986, p.31, tradução nossa).

Com a eclosão da Primeira Guerra Mundial, em 1915, a família de Svevo foi obrigada a abandonar Trieste, deixando-o só para dirigir a empresa do sogro, fechada em seguida pelos austríacos. Com a interrupção das atividades profissionais, nosso escritor retomou seus estudos literários entregando-se à leitura dos autores ingleses e à tradução, em 1918, juntamente com o médico e sobrinho Aurelio Finzi, do volume de Freud, Interpretazione dei sogni.

Para o escritor triestino, essa guerra, e tudo relacionado a ela, era condenável. A esse propósito, escreveu um ensaio intitulado Sulla teoria della pace, uma espécie de esboço de um projeto maior sobre a paz universal. Segundo Svevo, a guerra é, e permanece, algo torpe para todo homem equilibrado e moral. A sua infâmia não é diminuída nem pelo patriotismo nem pelo heroísmo ${ }^{7}$ (CLAAR, 1986, p.30, tradução nossa).

Finda a guerra, Svevo começou a escrever sua obra prima. Durante três anos, de 1919 a 1922, ele dedicou-se intensamente à escritura de seu terceiro romance, A consciência de Zeno, publicado no ano de 1923, pela editora Cappelli. Inicialmente, o romance não causou grande euforia no público leitor e muito menos na crítica que permaneceu em silêncio.

Mais uma vez incompreendido, ele resolveu recorrer ao amigo Joyce que se encontrava em Paris, onde já era reconhecido como escritor. Assim, Svevo enviou o romance para que o amigo lesse e opinasse. A resposta de Joyce veio em tom lisonjeiro, vejamos: Por que se desespera? - lhe escreveu entre outras coisas - Deve saber que é sem a menor dúvida o seu melhor livro ${ }^{8}$ (CLAAR, 1986, p.32, tradução nossa).

Além de reconhecer a grandiosidade da obra, Joyce o aconselhou a enviar o romance a alguns amigos na França. Tratava-se dos italianistas Valery Larbaud, Benjamin Crémieux e, também, Thomas Stearns Eliot. Seu reconhecimento internacional estava por concretizar-se. 
No início de 1925, recebeu a primeira carta de Larbaud propondo o lançamento do livro na França. Em novembro do mesmo ano, dedicou-se à escritura de Corto viaggio sentimentale e, em dezembro, teve publicado na renomada revista literária L'esame, o artigo, Omaggio a Svevo, escrito pelo amigo e também escritor Eugenio Montale. Os dois anos seguintes, de acordo com Micaela Pretolani Claar, foram para Svevo preenchidos pela alegria do sucesso; Europa e America falam dele e ele se alimenta, com um prazer simples e espontâneo daquelas apreciações tão desejadas e, talvez, mais lisonjeiras do que ele esperava ${ }^{9}$ (CLAAR, 1986, p.86, tradução nossa).

Entre junho e julho de 1926, a editora Treves recusou a reimpressão de seu segundo romance, Senilidade. Ainda nesse ano, ele escreveu La madre, Una burla riuscita, Vino generoso, La novella del buon vecchio e della bella fanciulla. Já no ano de 1927, teve encenada, em Roma, sua peça Terzetto Spezzato, no teatro Indipendenti di A. G. Bragaglia.

Em 1928, iniciou um novo romance, Il vecchione ou Le confessioni del vegliardo, no qual Zeno continuaria a analisar sua vida sob o prisma da velhice. Contudo, a morte em um acidente automobilístico, o impediu de concluir seu quarto romance. Durante uma viagem de volta a Trieste, o carro em que estavam ele, a esposa e o neto Paolo chocou-se contra uma árvore. O escritor, ferido gravemente, foi levado ao pequeno hospital de Motta, em Livenza, com vida e ainda lúcido. Lá permaneceu por dois dias, até que seu coração não resistiu ao trauma. Antes do último respiro, ele ainda encontrou forças para reconfortar a filha e fumar o seu último cigarro, conforme suas próprias palavras reproduzidas pela esposa em Vita di mio marito, vejamos:

"Não chore Letizia, morrer não é nada."

Pede, inclusive, um cigarro:

"Este" disse "seria de fato o último."

"Quer rezar, Ettore?" lhe pediu Livia. E ele respondeu:

"Quando não se rezou durante toda a vida não basta no último momento" ${ }^{10}$. (CLAAR, 1986, p.34, tradução nossa) 
Em uma tarde de 13 de setembro de 1928, o mundo das letras perdia um escritor de grande peso e perspicácia, alvo de grande incompreensão por inserir uma narrativa nova, livre dos nós do passado. Sua grandiosidade e valor estão, sobretudo, em sua maneira de observar atentamente o eu mais profundo do homem burguês.

O reconhecimento tardio de sua obra talvez tenha origens justamente nesse seu modo de apreender a alma humana. A crítica, só nos anos 30, conseguiu reconhecer sua importância; o grande público o conheceu nos anos 50 .

Italo Svevo é importante por abrir um "novo mundo" à literatura italiana, renovando radicalmente as formas do romance, criando, um romance de vanguarda, especialmente com $A$ consciência de Zeno, em que o tempo objetivo é substituído pelo tempo da consciência e do monólogo interior, de modo que a trama tradicional é destruída. O romance, como bem observou o crítico Giacomo Debenedetti, faz parte do seu temperamento de escritor ${ }^{11}$ (DEBENEDETTI, 1995, p. 54, tradução nossa). Svevo atualmente é visto como o fundador do romance novecentesco e o romancista italiano mais europeu do século XX.

Assim, encerramos a síntese da majestosa biografia do eterno Italo Svevo. Sua história renderia um calhamaço de folhas. Nessa o que chama atenção é sua fiel crença em um grande sonho, sempre verdadeiro e nobre para ele, tornar-se escritor. Em meio a tantas dificuldades e obstáculos vividos, sua perseverança e amor a esse ideal de vida destacaram-se. Ele, sem sombra de dúvidas, viveu digna e intensamente, por isso aceitaria viver tudo de novo. Uma vida não pode ser suficiente para sua grandeza; solo una vita non può bastare para que sua história seja esquecida. 


\title{
1.3 ITALO SVEVO, HOMEM MÚLTIPLO
}

\author{
É difícil se conhecer um homem ainda que tenhamos vivido junto a \\ ele por longos anos. \\ Dostoievsky
}

\begin{abstract}
Sinto-me múltiplo. Sou como um quarto com inúmeros espelhos fantásticos que torcem para reflexões falsas uma única anterior realidade que não está em nenhuma e está em todas.
\end{abstract}

Fernando Pessoa

Svevo, em sua obra, pintou um homem cindido, fragmentado, múltiplo, um homem que busca seu autoconhecimento, enfim, um representante autêntico de sua época, do qual o próprio Svevo pode ser tomado como exemplo, uma vez que parece trazer consigo algumas características desse "novo" homem, entre elas, a multiplicidade, da qual discorreremos na seqüência.

O escritor triestino sempre viveu entre fronteiras, segundo Fabio Vittorini, de dois ou mais mundos diferentes e, de certa maneira, contrastantes: geopolíticos (Áustria e Itália), sócio-culturais (o comércio e a literatura), filosóficos (o positivismo e a psicanálise) e literários (o "sistema de Zola" e Joyce) (VITTORINI, 2004, p.1539). Svevo lançou um olhar "inédito" sobre eles, através de uma lente deformante e, ao mesmo tempo, corrosiva e sagaz. O dialogismo apresentou-se como uma constante em sua existência. De fato, ele sempre caminhou entre diferentes pólos e isso já fica evidenciado na escolha do nome com o qual ele se apresentará à sociedade. Ettore Schmitz, nome de batismo, o consagrará como comerciante de sucesso, Italo Svevo, nome artístico, o firmará como escritor. Assim, incluímos aos mundos visitados por nosso escritor a tênue fronteira entre a utilização de seu verdadeiro nome e de seu pseudônimo. 
Partindo de sua duplicidade geopolítica, encontramos a raiz da mesma, possivelmente, em sua cidade natal, Trieste. Esta faz fronteira com a Áustria e com a Eslovênia, sendo que pertencera ao Império Austro-Húngaro, do qual era o principal porto. Nessa época, Trieste, de acordo com Ramos, possuía um substrato cultural mais austríaco que italiano, visto que o território ainda era submisso a Viena (RAMOS, 2001, p.25).

Tal cidade constituiu-se em uma espécie de palco onde "conviveram" grandes confluências étnicas, lingüísticas, culturais, em que todas se misturavam, fundindo-se por vezes. Essa “caldeira” de raças e civilizações contribuiu na formação e composição dessa cidade “dialógica” (LUNETTA, 1976, p.18).

De acordo com Elio Apih, a época do nascimento, bem como da morte de Svevo incorrem exatamente com o advento e com a dissociação das instituições liberais de sua Trieste que, inicialmente, vive sob o domínio austríaco, sendo tardiamente anexada ao território italiano. (APIH, 1988, p.11). Dividido entre duas culturas, a alemã e a italiana, intrínsecas à sua formação, ele optou por viver as duas. Isso ficou bem claro na escolha de seu terceiro pseudônimo, Italo Svevo, em que vêm homenageadas suas duas "nações".

Nascido Ettore Schmitz, optou por utilizar artisticamente um nom de plume. O crítico Paolo Puppa defende que Svevo deveria assumir um pseudônimo, enquanto não fosse "aceito" no seio da Bolsa de Valores (Tergesteo) (PUPPA, 1995, p.34). Sabe-se que o escritor triestino fez uso de três pseudônimos durante sua vida, firmando-se artisticamente com o terceiro.

O uso de um segundo nome, de acordo com Puppa

denuncia uma relação perturbada com a paternidade, tanto que a mudança de sobrenome poderia coincidir com um parricídio pacífico, veja os estudos de Starobinski, eliminando o genitor da própria identidade! E, além do mais, na história das instituições dos registros de nascimento, tal gesto é permitido às mulheres e/ou artistas. Conseqüentemente, escolher um outro nome confere à atividade pela qual se realiza esta escolha um caráter sinistro, transgressivo e contemporaneamente, no caso do escritor, libera-se uma explícita componente feminina ${ }^{12}$. (PUPPA, 1995, p.34, tradução nossa)

Não pretendemos nos enveredar pelas questões edipianas em torno dos pseudônimos de Svevo. Nossa intenção é apenas demonstrar que o uso destes constitui em mais um 
instrumento para, de certa forma, reforçar a premissa de que nosso escritor, assim como seu personagem Zeno, passou a vida equilibrando-se entre dois pólos, entre dois "extremos", justificando daí sua multiplicidade.

Seu primeiro pseudônimo data da adolescência, época em que o futuro escritor almejava tornar-se ator. Tal desejo secreto fora confessado ao irmão predileto, Elio. Assim, nas primeiras manifestações dramatúrgicas, ele optou por usar o nom de plume Erode, personagem autoritário no imaginário antigo (PUPPA, 1995, pp.34-5). O segundo, Ettore Samagli, foi usado para assinar seu primeiro artigo, durante o aprendizado juvenil, como colaborador do jornal L'Indipendente. Cabe lembrar que esse pseudônimo foi usado, posteriormente, para nomear o protagonista do conto Una burla riuscita.

O terceiro e mais conhecido pseudônimo, que lhe consagraria como escritor, foi Italo Svevo. A escolha do mesmo ocorreu como uma maneira de o escritor homenagear sua dupla formação cultural. Assim, Italo representaria seu lado italiano e Svevo, o alemão. O pseudônimo também foi escolhido como uma medida preventiva em função de questões políticas, uma vez que os fascistas de Benito Mussolini haviam tomado o poder. Svevo, contudo, atribuiu tal escolha em função do papel de sua Trieste naquela época, vejamos:

Para compreender a razão de um pseudônimo que parece querer irmanar a raça italiana e a germânica, é preciso ter presente a função que, há quase dois séculos, Trieste vem exercendo na Porta Oriental da Itália: função de cadinho assimilador de elementos heterogêneos que o comércio e a dominação atraíram para a velha cidade latina. $\mathrm{O}$ avô de Italo foi funcionário imperial em Treviso, onde se casou com uma italiana. Seu pai, que viveu em Trieste, considerou-se, portanto, italiano e casou-se com uma italiana, com quem teve quatro filhas e quatro filhos. Ao seu pseudônimo, "Italo Svevo", foi induzido não pelos seus longínquos ancestrais alemães, mas pela estadia prolongada na Alemanha, quando adolescente ${ }^{13}$. (LUNETTA, 1976, pp.33-4, tradução nossa)

Constituindo-se em um cenário múltiplo e cosmopolita, Trieste, que só em 1918 foi anexada à Itália, abrigou em si o signo da diversidade, da multiplicidade, importante por determinar a personalidade de nosso escritor, o qual, como já acenado, vivenciou a duplicidade dos mundos sócio-culturais, oscilando entre as atividades comercias e a literatura. 
A propósito do trabalho como comerciante, Paolo Puppa ressalta que Svevo empenhou-se, exaustivamente, na construção de uma identidade como rico comerciante em uma progressiva integração junto à Bolsa de Valores (PUPPA, 1995, p. 33).

Para Micaela Pretolani Claar, o "dialogismo" (comerciante e escritor) formaria em Svevo o que ela chama de dupla "alma", em que coexistem dois personagens diferentes: o industrial triestino, formado em um colégio alemão, voltado às atividades comerciais e que trabalhou por muitos anos no banco e depois na fábrica do sogro; e o escritor italiano, apaixonado e fiel à sua vocação literária, que escreve romances mesmo sem ninguém ler, confiando à caneta a tarefa de analisar a sua vida (CLAAR, 1986, p.101). Para Claar, é essa dupla "alma" que garante a originalidade de Svevo.

A intensidade com que ele sempre se entregou às experiências, vivendo incessantemente no tênue "limite" de toda empreitada realizada, o tornou um respeitado e eficiente homem de negócios e, posteriormente, um dos maiores escritores do século XX. Atualmente, Svevo é considerado, segundo dados estatísticos publicados no suplemento literário Tuttolibri, do jornal La Stampa, de Turim, o mais importante escritor italiano do século XX. Em um plebiscito, realizado entre os leitores do jornal italiano, o romance $A$ consciência de Zeno, de Italo Svevo, foi escolhido com 3059 votos como o livro mais importante do século passado (CASTRO, 1985, p.8).

Em sua arte, podemos apreender a confluência de várias correntes filosóficas e literárias. Leitor atento e interessado, Svevo sempre se entregou à leitura dos grandes nomes da literatura, ciência e filosofia, entre eles Schopenhauer, Darwin, Nietzsche, Freud, Tchecóv, Marx, Dostoevsky, além dos grandes romancistas franceses, como Zola. De acordo com Micaela Pretolani Claar, para entender e "emoldurar" o nascimento e o crescimento de sua obra literária, é necessário aproximá-lo aos grandes escritores europeus que influenciaram as 
novas formas da narrativa do século XX: Proust, Joyce, Musil e Kafka (CLAAR, 1986, pp.102-3).

Svevo serviu-se da ideologia dos grandes pensadores para perscrutar e interrogar o caráter do homem de seu tempo. Cada escritor ou filósofo teve participação especial na constituição de sua Literatura. Assim, conforme Claar, podemos dizer que

Schopenhauer acentuará a sua congênita concessão pessimista da vida, sugerindo-lhe os meios para teorizar e exaltar a "inaptidão"; Darwin oferecerá a sua atenção e a sua necessidade de clareza, a teoria científica da evolução da espécie; Marx, por sua vez, lhe colocará a disposição as novas definições da sociedade, do trabalho e da luta de classe e Freud, finalmente, lhe dará os

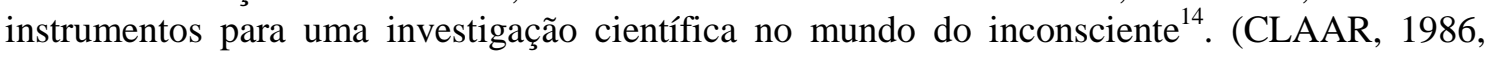
P.104, tradução nossa)

Mesmo bebendo dessas fontes, Svevo conseguiu imprimir à sua obra um caráter de autonomia em relação a elas. Isso porque mesclou essas teorias à sua visão pessoal, reelaborando-as e reinventando-as com seu talento de literato.

Svevo absorveu do legado desses estudiosos o que mais lhe interessava. De Schopenhauer, herdou não só o pessimismo, mas também a consciência de que a ambigüidade comportamental do homem não permite determiná-lo cientificamente.

A leitura de Marx, cuja temática de integração social ultrapassou o nível político, ganhando valor existencial e universal, foi essencial na visão do escritor triestino sobre a crise vivida pela burguesia, a qual se identificava com a crise do homem moderno.

Já através da teoria de Darwin, de acordo com Matteo Palumbo, Svevo extraiu uma característica determinante para sua obra, a representação das relações interpessoais como competitividade e luta. A propósito, seu primeiro conto, escrito em 1889, chama-se Una lotta. Como consequiência dessa luta, teríamos a divisão de seus personagens em fracos e fortes, sãos e moribundos, ineptos e capazes, vitoriosos e derrotados (PALUMBO, 2007, pp.140-1).

A visão de Nietzsche sobre a gaia ciência e o niilismo fornecem a base para a representação de Zeno, em A consciência de Zeno, uma vez que permitiu ao protagonista 
aprender a ouvir a música da negação da vontade, sem a lembrança da ascese (PALUMBO, 2007, p.149).

O ciclo dos principais filósofos que influenciaram nosso escritor termina com Sigmund Freud, de importância fundamental na tessitura de Zeno. Svevo, segundo Micaela Pretolani Claar, acreditava ter encontrado na teoria freudiana argumentos suficientes para explicar cientificamente o mundo interior do homem (CLAAR, 1986, p.111).

A psicanálise para ele, de acordo com Palumbo, transforma-se em um novo fundamento de ceticismo, uma parte misteriosa do mundo, sem a qual não se sabe mais pensar $^{15}$ (PALUMBO, 2007, p.150, tradução nossa). Freud

não lhe serve tanto porque prometa um tratamento à própria doença, uma cura individual impossível em uma "vida [...] contaminada até as raízes", mas porque permite iluminar os escuros da subjetividade, e refletir sobre as razões, às vezes, misteriosas e inexplicáveis da qual dependem cada ação ${ }^{16}$. (PALUMBO, 2007, p.150, tradução nossa)

A teoria freudiana, certamente, foi importante por guiar Svevo pelos caminhos do inconsciente, como mais um meio de alcançar o conhecimento e entendimento do mais profundo "eu", intrínseco ao homem; bem delineado em seu terceiro romance na figura do burguês Zeno Cosini, que representa o homem de sua época, homem que poderia ser o próprio Svevo. A esse propósito, parte da crítica chegou a levantar algumas hipóteses questionando se Zeno poderia ser o próprio Svevo. Será mesmo? Vejamos alguns pontos em comum entre ambos, na seqüência. 


\title{
1.4 ITALO SVEVO E ZENO COSINI, VIDAS PARALELAS?
}

\author{
Os homens são parecidos em suas promessas. Eles só diferem em \\ seus atos. \\ Molière
}

\begin{abstract}
Somos nós mesmos apenas por causa dos olhos dos outros, e é a partir da visão dos outros que nos assumimos como nós.
\end{abstract}

Jean Paul Sartre

Muito indagou-se, e ainda indaga-se, se o romance A consciência de Zeno vem a ser uma autobiografia do escritor. Não pretendemos aqui defender e tentar provar que o romance seja uma autobiografia fiel à vida do escritor. Isso, a nosso ver, é irrelevante. Uma análise que priorize a comparação estrita entre obra e vida do autor reduziria a riqueza literária da mesma, inibindo um estudo dos meandros do fazer literário que julgamos o mais importante. Assim, pretendemos apenas fazer algumas aproximações entre o personagem fictício, Zeno Cosini, e o "personagem" real, Italo Svevo.

Tullio Kezich, em seu livro Svevo e Zeno: vite parallele, traça, a partir de uma biografia imaginária de Zeno Cosini, baseada em elementos do próprio romance, $A$ consciência de Zeno, e também daquele que seria o quarto romance de Svevo, inacabado devido à sua morte e publicado posteriormente como coletânea de contos, um paralelo entre a vida do personagem e a do seu criador, ressaltando alguns pontos de convergência entre ambos (KEZICH, 1970, p.9).

A primeira semelhança entre a vida dos dois encontra-se na cidade em que ambos nasceram, a cosmopolita Trieste. Svevo, como já vimos, nasceu no ano de 1861, enquanto Zeno teria nascido quatro anos antes, em 1857, ano aproximativo, de acordo com Kezich (KEZICH, 1970, p.15). 
Outra verossimilhança seria a proximidade da morte de seus pais. Zeno, conforme relata em suas memórias perdeu o pai em 15.4.1890, às 4 e $30^{17}$ (SVEVO, 2006, p.39). Já o pai de Svevo morreu dois anos depois, no dia $1^{\circ}$ de abril de 1892.

Zeno "visitou" as cadeias de combinações de carbono, fugindo delas; Svevo também entrou em contato com a Química através das vendas do verniz submarino da empresa do sogro; ambos "feriram" o violino para calar a voz do subconsciente (KEZICH, 1970, p.10). A esse respeito Micaela Pretolani Claar diz que Svevo

também freqüentou o círculo musical e começou a estudar violino, que seria o hobby por toda a vida: não por nada, também Zeno, o protagonista de seu terceiro romance, vai se queixar de não conseguir aprender a tocar bem ${ }^{18}$. (CLAAR, 1986, p.19, tradução nossa)

O senhor Cosini também recorreu ao violino como um pretexto, segundo ele, para visitar a casa de seu futuro sogro, e como uma maneira de fazer frente a seu rival, Guido Speier, exímio violinista. Cosini, sem a menor afinidade com o violino, foi obrigado a reconhecer seu fracasso e falta de talento com o instrumento musical. Vejamos:

Um violinista! Se era verdade que tocava tão bem, eu, simplesmente estava perdido. Se ao menos eu não tocasse violino ou não me tivesse deixado induzir a tocá-lo em casa dos Malfenti... Levara meu instrumento àquela casa não para conquistar com a música o coração daquela gente, mas como um pretexto para prolongar as minhas visitas. Que imbecil eu fora! Podia ter usado de tantos outros pretextos menos comprometedores!

(...) Sei que possuo alta sensibilidade musical e não é por afetação que busco a música mais erudita; mas esta mesma desenvolvida sensibilidade me adverte e há tantos anos me tem advertido de que nunca chegarei a tocar de modo a proporcionar prazer a quem me ouve. ${ }^{19}$ (SVEVO, 2006, p.117)

O ciúme pela esposa também faz parte do elenco de características comuns a eles. O medo de morrer e deixar a esposa viúva, "livre" para viver um outro amor, rondou tanto a mente de Svevo quanto de seu personagem. Zeno registrou tal receio em suas memórias, através da seguinte fala:

Fui então atacado por outra pequena enfermidade, da qual nunca me curaria. Uma coisa de nada: o medo de envelhecer e, sobretudo, o medo de morrer. Creio que tudo se originou de uma forma especial de ciúme. A velhice causava-me temor pelo fato de me aproximar da morte. Enquanto estivesse vivo, Augusta certamente não haveria de me trair; admitia, porém, que mal viesse a morrer e fosse sepultado, após providenciar para que meu túmulo fosse mantido em ordem e se 
rezassem em minha intenção as missas necessárias, ela imediatamente procuraria um sucessor, a fim de introduzi-lo neste mesmo mundo de saúde e regularidade que eu agora desfrutava. Sua bela saúde não poderia morrer apenas porque eu estivesse morto. Eu tinha tal fé naquela saúde que só podia vê-la perecer se esmagada por um trem a toda velocidade. ${ }^{20}$ (SVEVO, 2006, pp.162-3)

Como podemos notar, o ciúme nasce do pavor à velhice e à morte e também da inveja nutrida pela "bela saúde" da esposa, Augusta. Mais que ciúme, esse sentimento parece estar próximo da obsessão e da possessão. Não conseguimos vislumbrar nesse ciúme um sentimento verdadeiro, nobre. O que notamos é uma espécie de egoísmo, uma vez que predomina unicamente a preocupação com a imagem que deve ser mantida mesmo depois da morte. Colocar um "substituto" como marido mancharia a honra e também a masculinidade de ambos.

O “ciúme” de Svevo foi bem ressaltado por Livia, sua esposa:

a idéia de ser esquecido depois da morte por um segundo casamento nunca o deixou. Mesmo nos anos da nossa querida convivência, isto regressava insistentemente. Sempre teve vivo o ciúme póstumo por um possível rival, escrevendo até uma crônica humorística ${ }^{21}$. (LUNETTA, 1976, pp.35-6, tradução nossa)

Todo esse ciúme parece ser muito forte, uma espécie de sentimento visceral, intrínseco ao caráter de ambos. Presos a esse sentimento, sem poder fazer nada, eles deverão continuar a longa caminhada chamada vida, tentando "conviver" com todos seus fantasmas.

Nesse contexto, as esposas terão um papel importante. A esse propósito, Micaela Pretolani Claar sustenta que Livia é para Svevo assim como Augusta também será para Zeno, ou seja, a possibilidade de concretização da saúde, a certeza que não deixa espaço às dúvidas: é um ponto de apoio para um espírito destinado à inquietação e à solidão interior e sempre de forma desagradável no papel do protagonista ${ }^{22}$ (CLAAR, 1986, p.26, tradução nossa).

A conquista do sucesso profissional, via atividade comercial, também faz parte da lista de semelhanças entre eles. Zeno, cujo patrimônio fora administrado pelo senhor Olivi, após a morte do pai, consegue no final do romance, em um momento difícil - eclosão da Primeira 
Guerra Mundial — revelar-se um bom “comerciante”. Cosini atribuiu ainda ao comércio a sua cura. Vejamos:

Admito que, para chegar à persuasão de estar sadio, o meu destino teve de mudar e o meu organismo se escaldou na luta e sobretudo no triunfo. Foi o comércio que me curou e quero que o dr. S. o saiba.

Inerte e atônito, até o início de agosto ultimo, estive a olhar o mundo transtornado. Foi então que comecei a comprar. Sublinho o verbo para frisar que tem um significado mais amplo do que antes da guerra. Antes, na boca de um comerciante, significava que ele estava disposto a comprar determinado artigo. Contudo, quando agora o digo, quero significar que compro qualquer mercadoria que me for oferecida. Como todas as pessoas fortes, só tinha uma idéia em mente e dela vivi e com ela adquiri fortuna. Olivi não estava em Trieste, mas é certo que ele não teria permitido um risco semelhante e o reservaria aos outros. Para mim, ao contrário, não era um risco. Eu sabia do bom resultado com toda a certeza. A princípio, seguindo antigo costume em época de guerra, tratei de converter todo o meu patrimônio em ouro, embora houvesse certa dificuldade em comprar e vender ouro. O ouro por assim dizer líquido, porque mais móvel, era a mercadoria e tratei de açambarcá-la. Efetuo de tempos em tempos algumas vendas sempre em quantidades inferiores às adquiridas. Porque comecei no momento propício, minhas compras e vendas foram tão oportunas que me forneceram os grandes meios de que necessitava para adquiri-las. ${ }^{23}$ (SVEVO, 2006, pp.419-20)

Zeno consegue reverter seu quadro de inettitudine alcançando a suposta cura que, na verdade, seria a aceitação de sua doença. A “consagração" de Svevo como um considerável homem de negócios pode ser notada em uma carta que ele escreve à filha Letizia: "Estou me tornando um homem de negócios muito sério. Papai me dizia que teria juízo com 40 anos. Errou por 14...” ${ }^{24}$ (Kezich, 1970, pp.54-5, tradução nossa)

Uma última possível característica, tratada aqui, comum a eles, e de suma importância no romance, como veremos de forma mais detalhada posteriormente, é a obsessão pelo cigarro. Assim como Zeno, Svevo percorrerá sua existência nutrindo o bom propósito de parar de fumar.

O cigarro entrou na vida deles muito cedo. Svevo desde a época do colégio (CLAAR, 1986, p.20) e Zeno ainda criança, conforme fica explicitado por ele mesmo em suas memórias (SVEVO, 2006, p.17). Ambos "lutarão" continuamente para deixar esse vício, contudo o último cigarro permanecerá na constante promessa, jamais cumprida.

Svevo registrou a dificuldade de abandonar o cigarro em várias cartas endereçadas à esposa. Vejamos dois momentos que imortalizaram seu vício: 
"Declaro a minha "Dilleta" que este que estou fumando é o último cigarro ao menos até o dia em que pela sua bondade e dulcíssimo destino me será concedido dizer que é toda, toda minha. Ettore Schmitz ${ }^{25}$. (Kezich, 1970, p.38, tradução nossa)

"Seis horas da tarde, o último emplastro que mando a minha Livia com relação ao fumo. Que não mais se diga que é hora de parar. Não fumo mais: pela promessa conhecida, feita e não mantida. Para me tornar mais são e forte..." ${ }^{26}$. (Kezich, 1970, p.40, tradução nossa)

Zeno, como veremos mais detalhadamente no próximo capítulo, nunca chegará ao bom propósito de abandonar o fumo. O último cigarro será uma constante na sua vida e, acima de tudo, determinante para sua constituição.

Assim, chegamos ao fim deste pequeno trajeto, cuja pretensão maior foi aproximar algumas “curiosidades" comuns entre a existência de Svevo e Zeno. Reforçamos, porém, que embora existam semelhanças entre a vida dos dois, não podemos afirmar, nem concordamos, que Zeno, na verdade, seja uma cópia fiel de seu criador. Zeno não é Svevo, mas a consciência narrante do romance, a lente pela qual é visto o mundo ${ }^{27}$, uma espécie de filtro com a função de transformar a experiência humana em um novo, ou inédito universo significante $^{28}$ (LAURETIS, 1976, pp.126-7, tradução nossa). 


\section{Notas}

1 I quattro ragazzi e le quattro ragazze (Paola, Natalia, Noemi, Adolfo, Ettore, Elio, Ortensia, Ottavio) intelligenti e pieni di vita, crescevano in grande cameratismo. La mamma temperava con la sua dolcezza la severità paterna. Si chiamava Allegra e qualcosa del suo nome emanava da lei rischiarando l'atmosfera all'intorno. Spesso si metteva alla finestra per guardare i suoi figlioli uscire tutti insieme. Erano come le canne dell'organo. Formavano una scala, ma di frequente ne mancava uno: Ettore rimasto ultimo, il distratto che smarriva ogni cosa /.../. La piccola società intelligente, ricca di iniziativa, inventata a getto continuo nuovi divertimenti.

Avevano persino creato un giornale scritto a mano e ciascuno dei fratelli ne redigeva una parte. Tutti gli avvenimenti domestici vi erano annotati e spesso commentati con molto umorismo. Vi si notava lo zampino di Adolfo che era di temperamento allegro e burlone. L'unica copia ingiallita conservata fra i ricordi di famiglia porta l'ermetico titolo di Adotajejojade. La strana parola era formata dalle iniziali dei diminutivi famigliare.

2 Ettore era sempre più attratto dalla letteratura e soffriva di non dominare perfettamente la lingua, sia per l'istruzione avuta in una scuola straniera, sia per l'abitudine continua del dialetto, usato anche dalle classi colte triestine nel parlare famigliare. E coltivava segretamente un sogno: quello di convincere il padre a mandarlo per qualche anno a Firenze per apprendere la lingua dalle vive fonti. Sapeva tuttavia che questo non era che un bel sogno, e che il suo destino era di diventare commerciante come il fratello Adolfo. Così era stato stabilito dal padre. La letteratura era una cosa lontanissima dalla mentalità del vecchio Schmitz ed Ettore, nonostante la sua ardente vocazione di scrittore, non aveva la forza di opporsi alla volontà del padre, che reggeva con ferma autorità la famiglia, la cui prosperità andava declinando.

3 Il successo del romanzo in Italia fu nullo del tutto. Nessun giornale italiano se ne occupò, fuori dell' "Indipendente" che lo aveva pubblicato nelle proprie appendici. Persino a Trieste il giornale più importante ( cioè il "Piccolo della Sera") non ne volle parlare perché il romanzo era stato pubblicato nelle appendici del giornale concorrente.

${ }^{4}$ L'irlandese, che non aveva mai parlato ad alcuno dei suoi lavori letterari, portò ben presto i suoi manoscritti a Villa Veneziani. Erano le poesie di "Chamber music" ed alcuni capitoli dei Dubliners. Trascinato da questi entusiasmi letterari, un giorno Svevo presenta al giovane i suoi due vecchi romanzi, come per dirgli: Anch'io fui uno scrittore. Joyce li lesse subito e durante la lezione successiva dichiarò che, secondo la sua opinione, Svevo era stato ingiustamente negletto. Aggiunse con calore che certe pagine di Senilità non avrebbero potuto scriverle meglio i più grandi maestri del romazo francese. A quelle parole inaspettate un balsamo scendeva sul cuore di Ettore. Egli lo guardava con grandi occhi incantati, beato e stupito. Mai avrebbe pensato di sentire tante lodi dei suoi romanzi dimenticati.

${ }^{5}$ Grande uomo quel nostro Freud, ma più per i romanzieri che per gli ammalati. Un mio congiunto uscì dalla cura durata per vari anni addirittura distrutto. Fu per lui che io, una quindicina di anni or sono, conobbi l'opera del Freud. E conobbi alcuni di quei medici che lo circondano.

${ }^{6}$ comprendere e definire la malattia congenita della vita.

${ }^{7}$ la guerra è, e resta, una cosa turpe per ogni uomo equilibrato e morale. La sua turpitudine non è diminuita né dal patriotismo né dall'eroismo.

${ }^{8}$ Perché si dispera? - gli scrive tra le altre cose - Deve sapere che è di gran lunga il suo migliore libro.

${ }^{9}$ furono per Svevo riempiti dalla gioia del successo; Europa e America parlano di lui e egli si nutre con piacere semplice e spontaneo di quegli apprezzamenti tanto desiderati e forse mai sperati così lusinghieri.

10 "Non piangere Letizia, non è niente morire."

Domanda persino una sigaretta:

"Questa" dice "sarebbe davvero l'ultimo."

"Ettore vuoi pregare?" gli chiede Livia. E lui risponde:

"Quando non si è pregato tutta la vita non serve all'ultimo momento".

${ }^{11}$ fa parte del suo temperamento di scrittore. 
12 denuncia un rapporto disturbato colla paternità, tanto che il mutarsi il cognome potrebbe coincidere con un parricidio pacifico, vedi gli studi di Starobinski, eliminando il genitore dalla propria identità! E, del resto, nella storia delle istituzioni anagrafiche, tale gesto è consentito alle donne e/o agli artisti. Di conseguenza, scegliersi un altro nome conferisce all'attività per cui si attua questa scelta un carattere sinistro, trasgressivo e contemporaneamente, nel caso dello scrittore, si libera una esplicita compontente femminina.

${ }^{13}$ Per comprendere la ragione di uno pseudônimo che sembra voler affratellare la razza italiana e quella germanica, bisogna aver presente la funzione che da quasi due secoli va compiendo Trieste alla Porta Orientale d'Italia: funzione di crogiolo assimilatore degli elementi eterogenei che il commercio e anche la dominazione straniera attirarono nella vecchia città latina. Il nonno d'Italo Svevo era stato un funzionario imperiale a Treviso, dove sposò un'italiana. Il padre suo, perciò, essendo vissuto a Trieste, si considerò italiano, e sposò un'italiana da cui ebbi quattro figliole e quatro maschi. Al suo pseudonimo "Italo Svevo" fu indotto non dal suo lontano antenato tedesco, ma dal suo prolungato soggiorno in Germania nell'adolescenza.

${ }^{14}$ Schopenhauer accentuerà la sua congênita concezione pessimistica della vita e gli sugerirà i mezzi per teorizzare ed esaltare 1' "inettitudine"; Darwin offrirà alla sua attenzione e al suo bisogno di chiarezza la teoria scientifica della evoluzione della specie; Marx, invece, gli metterà a disposizione le nuove definizione della società, del lavoro e della lotta di classe e Freud, infine, gli darà gli strumenti per una indagine scientifica nel mondo dell'inconscio.

15 "un nuovo fondamento di scetticismo, una parte misteriosa del mondo, senza la quale non si sa più pensare"

${ }^{16}$ non gli serve tanto perché prometta una cura alla propria malattia, una guarigione individuale impossibile in una "vita [...] inquinata alle radici", ma perché permette di illuminare gli oscuri della soggettività, e di riflettere sulle ragioni talvolta misteriose e inesplicabili da cui dipendono i singoli atti.

${ }^{17} 15.4 .1980$ ore 4 1/2. (p.48)

${ }^{18}$ frequentò anche il circolo musicale e iniziò a studiare il violino, che sarebbe rimasto l'hobby di tutta la vita: non per niente, anche Zeno, il protagonista del suo terzo romanzo, rimpiangerà di non aver mai imparato a suonare bene.

${ }^{19}$ Un violinista! Se era vero ch'egli sonava tanto bene, io, semplicemente, ero un uomo distrutto. Almeno non avessi sonato io quell'istrumento o non mi fossi lasciato indurre di sonarlo in casa Malfenti. Avevo portato il violino in quella casa non per conquistare col mio suono il cuore della gente, ma quale un pretesto per prolungarvi le mie visite. Ero stato una bestia! Avrei potuto usare di tanti altri pretesti meno compromettenti!

(...) So di avere un alto sentimento musicale e non è per affettazione ch'io ricerco la musica più complessa; però il mio stesso alto sentimento musicale m'avverte e m'avvertì da anni, ch'io mai arriverò a sonare in modo da dar piacere a chi m'ascolta. (pp.119-20)

${ }^{20}$ Ma mi colse allora un'altra piccola malattia da cui non dovevo più guarire. Una cosa da niente: la paura d'invecchiare e sopratutto la paura di morire. Io credo abbia avuto origine da una speciale forma di gelosia. L'invecchiamento mi faceva paura solo perché m'avvicinava alla morte. Finché ero vivo, certamente Augusta non m'avrebbe tradito, ma mi figuravo che non appena morto e sepolto, dopo di aver provveduto acché la mia tomba fosse tenuta pieno ordine e mi fossero dette le Messe necessarie, subito essa si sarebbe guardata d'intorno per darmi il successore ch'essa avrebbe circondato del medesimo mondo sano e regolato che ora beava me. Non poteva mica morire la sua bella salute perché ero morto io. Avevo una tale fede in quella salute che mi pareva non potesse perire che sfracellata sotto un intero treno in corsa. (p.160)

${ }^{21}$ l'idea di essere cancellato dopo la morte da un secondo matrimonio non lo lasciò più. Anche negli anni della nostra cara convivenza vi ritornava insistentemente. Ebbe sempre viva la gelosia postuma verso un presunto rivale e ne scrisse persino un bozzetto umoristico.

22 è un punto di appoggio per uno spirito destinato alla inquietudine e alla solitudine interiore e sempre a disagio nel ruolo del protagonista.

${ }^{23}$ Ammetto che per avere la persuasione della salute il mio destino dovette mutare e scaldare il mio organismo con la lotta e sopratutto col trionfo. Fu il mio commercio che mi guarì e voglio che il dottor S. lo sappia. 
Attonito e inerte, stetti a guardare il mondo sconvolto, fino al principio dell'Agosto dell'anno scorso. Allora io cominciai a comperare. Sottolineo questo verbo perché ha un significato più alto di prima della guerra. In bocca di commerciante, allora, significava ch'egli era disposto a comperare un dato articolo. Ma quando io lo dissi, volli significare ch'io ero compratore di qualunque merce che mi sarebbe stata offerta. Come tutte le persone forti, io ebbi nella mia testa una sola idea e di quella vissi e fu la mia fortuna. L'Olivi non era a Trieste, ma è certo ch'egli non avrebbe permesso un rischio simile e lo avrebbe riservato agli altri. Invece per me non era un rischio. Io ne sapevo il risultato felice con piena certezza. Dapprima m'ero messo, decondo l'antico costume in epoca di guerra, a convertire tutto il patrimonio in oro, ma v'era una certa difficoltà di comperare e vendere dell'oro. L'oro per così dire liquido, perché più mobile, era la merce e ne feci incetta. Io effettuo di tempo in tempo anche delle vendite ma sempre in misura inferiore agli acquisti. Perché cominciai nel giusto momento i miei acquisti e le mie vendite furono tanto felici che queste mi davano i grandi mezzi di cui abbisognavo per quelli. (pp.393-4)

24 "Sto diventando un uomo d'affari molto serio. Papà mi diceva che avrei messo giudizio a 40 anni. Sbagliò di $14 . . . "$

25 "Dichiaro alla mia Diletta che questa che sto fumando è l'ultima sigaretta almeno fino al giorno in cui per sua bontà e per dolcissimo destino mi sarà dato di dirla tutta, tutta mia. Ettore Schmitz".

26 “'Ore sei pomeridiane L'ultimo cataplasma che mando alla mia Livia relativamente al fumo. Non se ne parli più ch'è ora di finirla. Non fumo più: I per la promessa notissima fatta e finora non mantenuta. Il per divenire ancora qualcuno o qualche cosa di sano e forte....".

${ }^{27}$ Zeno non è Svevo ma la coscienza narrante del romanzo, la lente attraverso cui è visto il mondo

${ }^{28}$ in un nuovo, o inedito universo significante 


\section{A CRIAÇÃO DE ZENO COSINI}

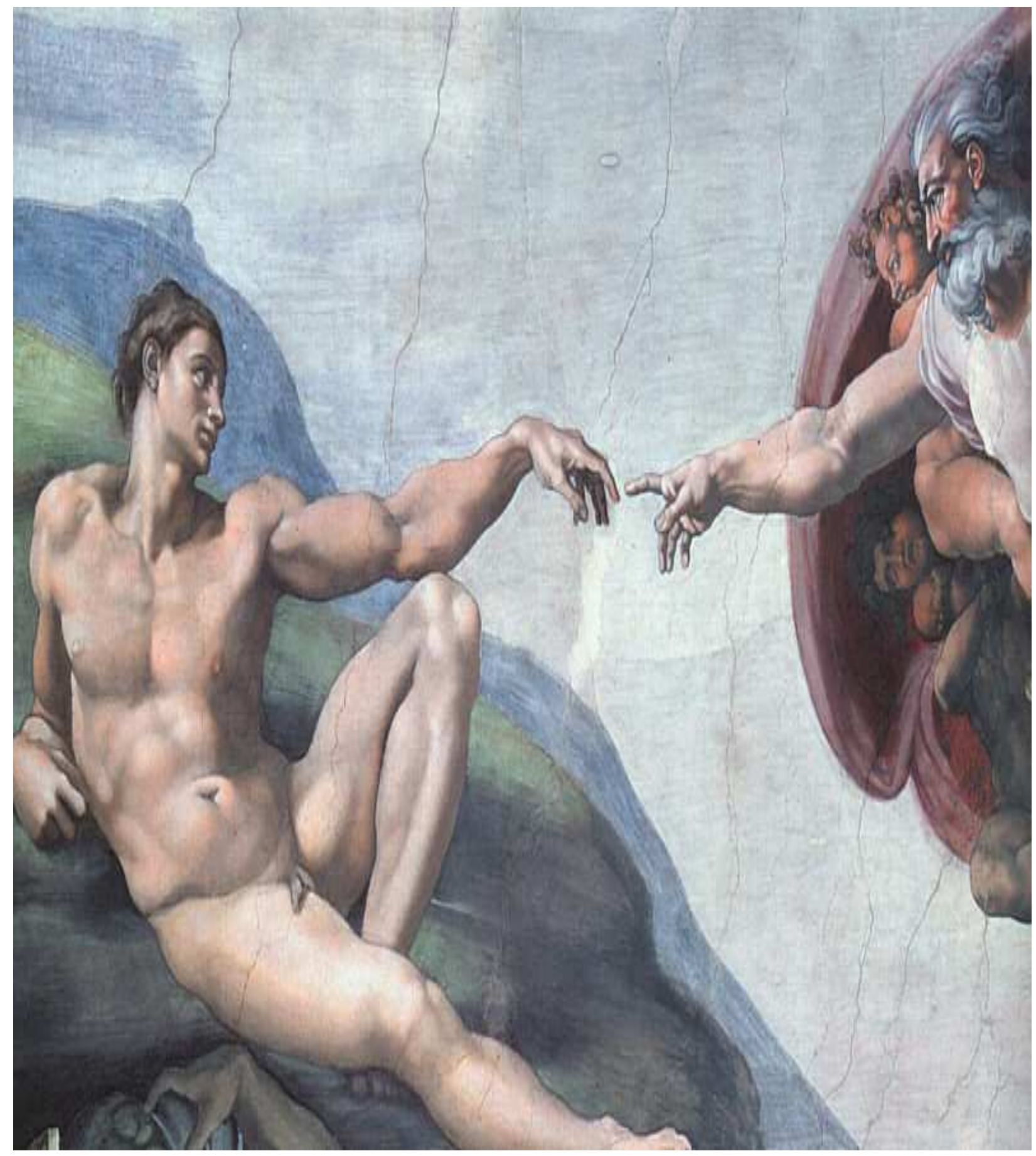

The Creation of Man. (1508-1512) Michelangelo Buonarroti 


\subsection{ZENO COSINI, HERÓI DE SEU TEMPO?}

As maiores almas são tanto capazes dos maiores vícios como das maiores virtudes.

Descartes

O romance A consciência de Zeno traz consigo grande confluência de ideologias e de tendências. Os pressupostos de Schopenhauer, Nietsche, Darwin e Freud "povoam" o romance, "convivendo" em harmonia com a literatura. Servindo-se de uma metáfora do próprio Svevo, podemos dizer que do "casamento" entre Filosofia e Literatura, em que há brigas e quase nenhum dos cônjuges se entende, nasceria um belo filho, o burguês Zeno Cosini.

Zeno, sem dúvida, é a grande criação do escritor triestino. Svevo começou a dar vida a esse personagem, que se tornaria um dos maiores, mais complexos e bem lapidados da literatura, muito cedo. O embrião que daria "vida" ao senhor Cosini, começou a ser "fertilizado", podemos dizer, em 1892, ano da publicação de Uma vida, com o personagem Alfonso Nitti. Anos mais tarde, em 1898, com a publicação de Senilidade, teríamos em Emilio Brentani um personagem, por assim dizer, mais delineado, mais próximo, talvez, das características que dariam "feição" e contornos, ainda que meio "borrados", a sua enigmática “invenção”. O personagem Emilio Brentani, de fato, é importantíssimo para se chegar a Zeno, pois, como afirma Mario Lunetta, Brentani já olha para Zeno Cosini, como a um convite irrecusável: do inferno da "senilidade”, a ponte para a inquieta calma da "consciência", já foi lançada ${ }^{1}$ (LUNETTA, 1976, p.100, tradução nossa).

Contudo, depois da publicação de Senilidade, o grande criador parece sair de cena. Na verdade, Svevo não havia recebido, como já ressaltamos, bom acolhimento por parte da crítica com seus dois primeiros romances. De certo modo, alvo de grande incompreensão por 
essa crítica que não conseguia ver o verdadeiro valor de suas obras, o escritor triestino optou por calar-se, abandonar o cenário das letras e dedicar-se às atividades comerciais.

Foram 25 anos de aparente silêncio, vistos pelo crítico Mario Lunetta como um período de incansável reflexão, de investigação profunda e de tensão para a maturidade humana, cultural e expressiva, na qual se situa naturalmente a experiência da última fase da trilogia romanesca do triestino ${ }^{2}$ (LUNETTA, 1976, p.100, tradução nossa).

Uma longa "gestação", pode-se assim dizer, até o nascimento de seu principal romance, A consciência de Zeno, que formaria junto com seus dois romances anteriores uma trilogia, cujo objeto de análise, de acordo com Teresa de Lauretis, seria sempre o mesmo: $a$ condição humana, a relação entre o eu e o mundo, os modos, os porquês, os como da existência, as formas do universo da consciência ${ }^{3}$ (LAURETIS, 1976, p.134, tradução nossa).

Esse "silêncio" de Svevo suscita, até hoje, várias indagações, entre elas: será que de fato o escritor triestino teria ficado todo esse tempo sem empunhar a caneta? Ele que dizia que o escrever era importante para se conhecer o nosso mais profundo e complicadíssimo eu? Preferimos acreditar que se tratou de um silêncio necessário, "estratégico", ou como afirma o crítico Lunetta, um período de longa reflexão (LUNETTA, 1976, p.100), para que nosso escritor se "fortalecesse", amadurecesse suas idéias e pensamentos, aflorasse, ainda mais, sua maneira de "olhar" a criação divina, o homem.

Eni Pulccinelli Orlandi, em seu livro intitulado As formas do silêncio no movimento dos sentidos, apresenta algumas considerações sobre os sentidos do silêncio, procurando indicar algumas "pistas" para se chegar ao princípio da significação. De acordo com Orlandi, o silêncio é a própria condição da produção de sentido. Ele não é o vazio, o sem-sentido; ao contrário, ele é o indício de uma totalidade significativa. (ORLANDI, 1995, p.70). Assim, poderíamos pensar o "silêncio" de Svevo como determinante na significação de seu último romance, estudado aqui por nós. Tão ambíguo quanto às palavras (ORLANDI, 1995, p.105), 
o silêncio, ao qual nosso escritor triestino recorreu, imprimirá à narrativa um caráter não menos ambíguo e enigmaticamente significante.

Vale ressaltar, ainda, que, embora a obra tenha sido publicada em 1923, somente dois anos mais tarde, em 1925, seria descoberta por Eugenio Montale e, no ano seguinte, ganharia, conforme Marzia Vicentini, reconhecimento francês por parte dos italianistas, Benjamin Crémieux e Valéry Larbaud em 1926, após indicação de James Joyce (VICENTINI, 1984, p.2). A consagração tardia de Svevo, bem como a posição particular que ele ocupou no quadro das tendências da literatura italiana contemporânea (VICENTINI, 1984, p.2) chegaram a constituir o que ficaria conhecido como o caso-Svevo. A esse propósito, é interessante apreendermos a posição tomada por Vicentini,

se poderia pensar que o verdadeiro caso-Svevo, de fato, não foi o sucesso tardio deste escritor e a posição particular que ele ocupou no quadro das tendências da literatura italiana contemporânea, mas sobretudo a avalancha de controvérsias, análises, estudos, diatribes, intervenções críticas, reformulações de questões etc. que ele ocasionou. (VICENTINI, 1984, p.2)

Concordamos com a estudiosa que o cerne da questão não está no sucesso tardio de Svevo, mas no impacto que sua obra causou às letras, tornando-o, como afirma Debenedetti, um romancista de importância excepcional (DEBENEDETTI, 1987, p.517). Sua narrativa, como estudaremos posteriormente, é transgressora, representa uma ruptura com o modelo "tradicional" e fornece ao romance novos patamares éticos e estéticos.

Assim, também é o senhor Zeno Cosini, um “transgressor”. Sua longuíssima "gestação", o período que permaneceu em "observação", adormecido em seu "tubo de ensaio", à espera do momento oportuno para ser inseminado e nos dar o ar de sua graça, foi imprescindível para sua constituição enigmática, ambígua, múltipla e "contraventora”. Svevo, de fato, até chegar a Zeno, sua inegável obra-prima, conseguiu, ainda mais, aprimorar suas técnicas, apreender o homem em sua totalidade, com todas as angústias e alegrias, dúvidas e 
frustrações, enfim, um homem que seria, podemos assim chamar, um verdadeiro "herói" romanesco, representante fiel de seu tempo.

Victor Brombert, no texto Em louvor de anti-heróis: figuras e temas da moderna literatura européia, estuda a figura do "anti-herói” na literatura, especialmente dos séculos XIX e XX. Para o crítico, as fronteiras que separam o que é heróico do não-heróico encontram-se em suspenso, seus limites foram "derrubados" (BROMBERT, 2001, p.14). Segundo ele,

A literatura dos séculos XIX e XX está, além disso, abarrotada de personagens fracos, incompetentes, dessorados, humilhados, inseguros, ineptos, às vezes abjetos - quase sempre atacados de envergonhada e paralisante ironia, mas às vezes capazes de inesperada resistência e firmeza. Esses personagens não se ajustam aos modelos tradicionais de figuras heróicas; até se contrapõem a eles. Mas pode haver grande vigor nessa oposição. Implícita ou explicitamente lançam dúvidas sobre valores que vêm sendo aceitos ou que foram julgados inabaláveis. (BROMBERT, 2001, p.14)

Zeno traz consigo várias das características elencadas por Brombert. Por um lado, ele mostra-se fraco, inepto, incompetente, mau caráter, leviano e mentiroso, mas por outro é bemfalante, refletido, hiperconsciente (BROMBERT, 2001, p.22). Cosini parece posicionar-se entre extremos; em determinados momentos, demonstra ser educado, gentil, enquanto em outros demonstra sua fraqueza, sua incapacidade de entender-se e de entender o mundo que o rodeia. Na verdade, ele procura e quer "re-"conhecer-se e, para isso, percorrerá o longo caminho narrativo procurando respostas, buscando saber quem de fato ele é. A narrativa será importante para que ele (re-)/(des-)construa sua "verdadeira" identidade, cosida pelos fios de um discurso ambíguo e irônico. Através de seus comentários, e pelos indícios e pistas deixados ao longo do texto, conseguiremos investigá-lo melhor.

Essa "construção identitária", por intermédio da narrativa, é alvo de vários estudos, dentre eles o de Araguaia Solange de Souza Roque, para quem Zeno é

um personagem-narrador que reconstrói sua vida de maneira lacunar, erigida à medida em que é narrado, "(re-)construindo-se" no discurso e podendo ser revestido de conotações que atendam a um propósito conforme seu interesse no momento da narração, ainda que por vezes, demonstre ingenuidade. (ROQUE, 2005, p.138) 
Só poderemos tentar entender e conhecer Zeno através de uma análise minuciosa e atenta de suas "memórias", para assim não corrermos o risco de sermos "enganados" por ele. Para fugirmos a seus engodos, é preciso, como aconselha o crítico italiano Guido Almansi ao falar da leitura da obra-prima de Boccaccio, entrar no texto de maneira oblíqua, lateralmente, pela porta de serviço ${ }^{4}$ (ALMANSI, 1992, p.9, tradução nossa).

É importante lembrarmos que Zeno não escreve para si próprio, ainda que o último capítulo seja estruturado em forma de diário, devemos ter em mente que ele escreve para um destinatário, o Doutor S. e esse fato muda a perspectiva da escrita e da leitura.

Para exemplificarmos tal afirmação, podemos pensar em outra confissão, a do defunto-autor Brás Cubas, de Machado de Assis, que não escreve a um destinatário estabelecido e, por estar morto, pode-se "mostrar" por inteiro, relatando sua vida passada sem se preocupar com julgamentos; Zeno, por sua vez, escreve sabendo que suas "memórias" serão lidas por seu suposto psicanalista. Diante disso, como afirma Teresa de Lauretis, não podemos ter certeza se Zeno mente ou não em função desse destinatário "imposto" à narrativa (LAURETIS, 1976, p.109). Assim, devemos desconfiar de seu discurso, lançando sobre ele um olhar inquisidor a fim de chegarmos a uma possível sentença para nosso "réu".

Brombert dedica parte de seu livro especificamente ao personagem Zeno, tomando-o como exemplo de "anti-herói" ou "herói moderno", como ele mesmo chama. Diante disso fica-nos algumas questões: Mas, afinal, Zeno é herói ou anti-herói? Que herói é esse, cheio de fraquezas e "imperfeições"?

Se levarmos em conta suas características, pesando seus defeitos, vícios e as poucas "virtudes", teremos um saldo negativo, ou seja, nosso protagonista aproximar-se-ia mais ao protótipo do "anti-herói" tradicional, representado pela ênfase dada às suas fraquezas. Não cabe aqui traçarmos as diferenças entre o herói épico e o "moderno", pois isso seria inviável 
ao nosso estudo e desviar-nos-ia de nosso objetivo primeiro, assim teceremos apenas uma comparação bastante superficial entre ambos.

O teórico russo M. Bakhtin, aponta em seu texto Questões de literatura e estética: a teoria do romance, a diferença primordial entre o herói épico e o herói romanesco, afirmando que este último não apenas age, mas também fala (BAKHTIN, 2002, p.136), ou seja, adquire no romance uma iniciativa ideológica e lingüística que modifica a sua figura (BAKHTIN, 2002, p.426). Desse modo, enquanto o herói "tradicional" não questiona, não contesta a sociedade em que vive, defende seus valores e assume seu discurso, nosso "anti-herói” quer falar, questionar, investigar, perscrutar, e até contestar a sua existência. Ao interrogar(-se), ao contestar(-se), nosso protagonista suscita, de acordo com Brombert, a questão de como nós nos vemos ou queremos ver (BROMBERT, 2001, p.14). Este ver-se ou querer ver-se, sem dúvida, acompanhará nosso protagonista por toda a narrativa. Zeno, no fundo, deseja se ver e ser visto como um homem respeitável, bem sucedido, bom marido, ou seja, imbuído de “qualidades" pregadas pela sociedade nas mais diferentes épocas. Todavia, ele sabe que não corresponde a esse modelo, vê-se como um homem com defeitos, vícios, "doente", "marginal” e libidinoso, como ele próprio deixa implícito em uma de suas falas. Vejamos:

Tenho 57 anos e estou certo de que se não deixar de fumar ou se não for curado pela psicanálise, em meu leito de morte meu último olhar será de desejo pela minha enfermeira, se esta não for minha mulher e se minha mulher tiver permitido que ela seja bela!

Fui sincero como se me confessasse... ${ }^{5}$ (SVEVO, 2006, p.24)

Essa passagem é importante para reforçar nossa premissa. Zeno deixa claro que quer continuar a ser "doente", libidinoso e fumante sempre, até o último cigarro ou suspiro. Nosso protagonista é um transgressor e, conforme suas próprias palavras, não deixará de sê-lo. Ele viverá sempre entre um propósito e outro, entre uma escolha e outra. Pode-se dizer ainda que a posição tomada por Zeno, de certa forma, ironiza o modelo ideal de homem de bem que vive em função das aparências, ou seja, do modo como deve apresentar-se à sociedade. 
Para Teresa de Lauretis, Zeno constitui-se em um verdadeiro "herói", pois aos 57 anos, momento em que narra sua vida, apresenta uma história recheada de experiências invejáveis, sobrevivendo a uma guerra e, ainda, tirando proveito desta. O burguês, segundo a crítica, consagra-se vencedor com a derrota daqueles que ousaram enfrentá-lo. Assim, aquele que aparentava ser o autêntico herói da história, Guido, "rival" de Zeno, morre de maneira cômica ao tentar simular um suicídio, bem como a "bela donzela", Ada, é "punida", por recusar o amor de nosso herói, descobrindo a traição do marido, ficando viúva e sendo acometida pela doença que lhe exauriu toda a beleza ${ }^{6}$ (SVEVO, 2006, p.279). Lauretis intitula essa série de acontecimentos como o verdadeiro "progresso do herói”. (LAURETIS, 1976, p.42).

O crítico Mario Lunetta também compartilha da "tese" apresentada por Teresa de Lauretis. De acordo com ele, Zeno dentro dos limites de seu território (...) resulta o mais forte, e termina sendo o vencedor ${ }^{7}$ (LUNETTA, 1976, p.110, tradução nossa). Os dois críticos parecem concordar que, no final das tantas "batalhas" empreendidas, Zeno termina por vencer uma guerra, que é, na verdade, exclusivamente sua.

De antemão, já podemos notar a complexidade acentuada de nosso protagonista que pode ser classificado como uma personagem modelada, de acordo com o estudo realizado pelo crítico português Vitor Manuel de Aguiar e Silva (AGUIAR E SILVA, 1983, p.710). Essas personagens, segundo o estudioso, são densas, enigmáticas, contraditórias, rebeldes às definições cômodas que podemos encontrar na cristalização das fórmulas (AGUIAR E SILVA, 1983, p.710). Tipos exemplares dos personagens descritos por Aguiar e Silva seriam os heróis de Stendhal, Tolstoj e James Joyce (AGUIAR E SILVA, 1983, p.710) e, claro, tomamos a liberdade de acrescentar, sem medo de cometer um equívoco, os heróis de Svevo, em especial, Zeno Cosini. 
Aguiar e Silva faz, ainda, outra colocação importante sobre essas personagens, ao afirmar que através das suas feições peculiares, das suas paixões, qualidades e defeitos, dos seus ideais, tormentos e conflitos, o escritor ilumina o humano e revela a vida (AGUIAR E SILVA, 1983, p.710). Partindo dessa premissa, podemos dizer que Zeno é importante por refletir sua humanidade, por revelar a vida como ela é. Uma vida que não é boa nem má; é original $^{8}$ (SVEVO, 2006, p.322), como ele próprio afirma. Nosso narrador parece ser um representante "fiel" das angústias e inquietações humanas; um personagem que traz consigo marcas de uma verdadeira humanidade, constituída mais por erros do que acertos, mais defeitos do que virtudes, mais simulacro do que veracidade.

Talvez seja, justamente, por essa "humanidade" de Zeno que encontramos dificuldade em apreendê-lo, em conhecê-lo totalmente, de modo a chegarmos a uma de sua(s) possível(is) identidade(s). Seus sentimentos contrastantes, suas ações estranhas, seu comportamento desconfiado, enfim, sua constituição genuinamente humana, o fazem um herói para sua época. 


\subsection{OS OLHARES DE ZENO, CONFIAR OU NÃO CONFIAR :}

\section{EIS A QUESTÃO!}

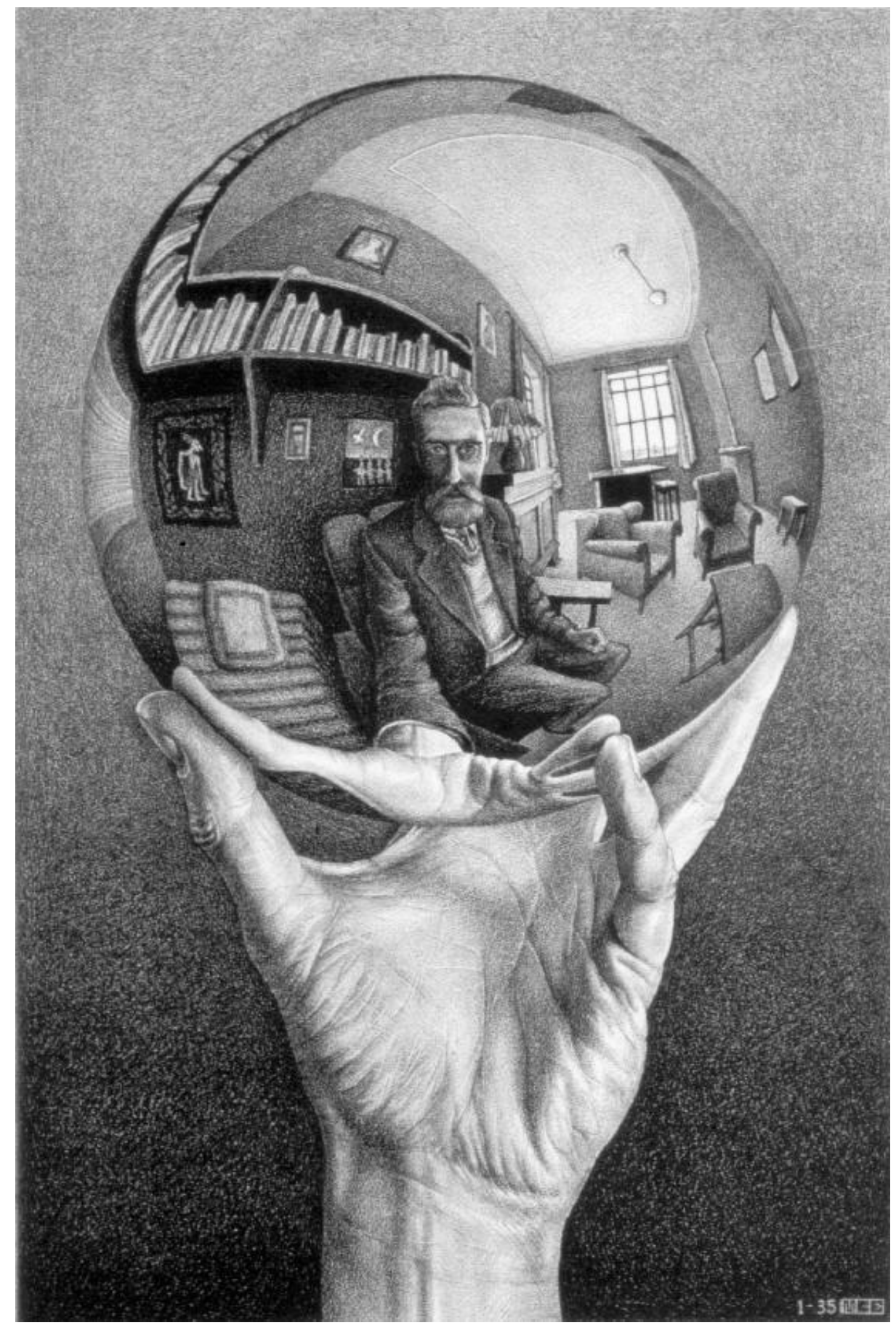

Hand and globe. (1935) Maurits Cornelis Escher 
É no uso das palavras que os homens traçam os fios lógicos e os fios expressivos do olhar.

Alfredo Bosi

De quem é o olhar Que espreita por meus olhos?

Quando penso que vejo,

Quem continua vendo

Enquanto estou passando?

Fernando Pessoa

Para Alfredo Bosi, o ato de olhar significa um dirigir a mente para um "ato de intencionalidade”, um ato de significação (BOSI, 1995, p.65), de modo que o olhar é importante por refletir a essência daquele que olha. Os olhos seriam, como bem ressaltou Da Vinci, as janelas da alma, às quais pretendemos descortinar e adentrar.

Somos convidados a conhecer o universo do romance A consciência de Zeno através do "olhar" de Zeno Cosini, que nos contará a história de sua vida, ou, como notou Sandro Maxia, a história de sua resistência à cura (MAXIA, 1990, p.40), pois, de acordo com o mesmo, a saúde

"não analisa si mesma" e muito menos se narra; esta pode ser narrada apenas do ponto de vista do doente e só a partir da recusa que o doente pronuncia sobre esta. Em outros termos, Zeno não é apenas o narrador de sua doença, mas também, e ao mesmo tempo, o narrador da "cruel saúde" dos outros (os considerados "sãos") ${ }^{9}$. (MAXIA, 1990, p.41, tradução nossa)

A doença, de fato, será uma constante em todo o romance. Ela é de extrema importância para que Zeno inicie sua narrativa. Para "julgarmos" a história de sua vida, ou melhor, de sua doença, devemos nos deixar guiar por seu olhar inquieto, obsessivo, à procura de uma possível "cura".

Com, e somente com, Zeno tomaremos nota de sua história, com ele conheceremos seu mundo. Assim, de acordo com a teoria de Poullion, poderíamos dizer que A consciência de Zeno aproxima-se da visão com, em que se escolhe um único personagem que constituirá o centro da narrativa... É com ele que vemos os outros protagonistas, é com ele que vivemos 
os acontecimentos narrados (POUILLON, 1974, p.54). Em conseqüência, segundo Maria Celeste Tommasello Ramos, estamos presos à visão de Zeno, e na impossibilidade de compartilharmos de outra visão, somos obrigados a permanecer com ele, vendo tudo através de seu ponto de vista ou procurando entender por que ele reage da forma que nos narra... (RAMOS, 2001, p.74).

Podemos considerar também, de acordo com Oscar Tacca, que o narrador, o sujeito da enunciação, de uma narrativa em primeira pessoa, é ainda mais dissimulado, assim, o relato em primeira pessoa não torna explícita a imagem do seu narrador, mas, ao contrário, tornaa mais implícita ainda (TACCA, 1983, p.87). Desse modo, não podemos, nem devemos confiar no autor, que parece mentir freqüentemente, mas confiar apenas no texto (ECO, 2006, pp.117-8).

Alfredo Leme Coelho de Carvalho, em consonância com esse pensamento, adverte que nas narrativas em primeira pessoa pode ocorrer a figura do narrador infiel (CARVALHO, 1981, p.47). Tal narrador, de acordo com caracterização de Carvalho, é um mentiroso, que mente deliberadamente, ou que faz uma falsa idéia dos fatos que descreve... (CARVALHO, 1981, p.47).

Zeno, logo de início, nos é apresentado como alguém que não é digno da menor credibilidade. Já no Prefácio, o suposto Doutor S. nos chama atenção acerca do caráter duvidoso e mentiroso do paciente. Vejamos o trecho em que isso fica claro:

Publico-as por vingança e espero que o autor se aborreça. Seja dito, porém, que estou pronto a dividir com ele os direitos autorais desta publicação, desde que ele reinicie o tratamento. Parecia tão curioso de si mesmo! Se soubesse quantas surpresas poderiam resultar do comentário de todas as verdades e mentiras que aqui acumulou!... ${ }^{10}$ (SVEVO, 2006, p.11)

A figura intrigante de tal médico, de acordo com Micaela Pretolani Claar, é importante por nos dar subsídios para entendermos a história de Zeno. A estudiosa italiana vê no psicanalista uma espécie de segundo narrador. De acordo com ela: 
o doutor S., que aparece somente no Prefácio, não tem apenas a função de apresentar o argumento e as intenções do narrador - tarefa tradicional dos prefácios - mas também e sobretudo aquela de dirigir-se diretamente ao leitor para informá-lo que Zeno, na reconstrução da própria vida, misturou verdade e mentira. Este improvável médico insere-se, assim, no romance como um segundo narrador e com seu tom meio ressentido e meio cativante em relação a Zeno, fornece ao leitor todas as informações necessárias para ler o relato de Zeno ${ }^{11}$. (CLAAR, 1986, pp.72-3, tradução nossa)

Franco Moretti, por sua vez, salienta que a figura do Doutor S. corrobora com mais indagações acerca do protagonista, suscitando perguntas como, "Qual 'verdade' Zeno irá narrar?", “A que convença ao médico, tendo para si uma outra?”, "Ou a 'verdade' que o traduz?". Nem mesmo Zeno saberia responder a tais perguntas. Essa impossibilidade de respostas, que esclareçam tais questões, é vista por Moretti como algo suspeito (MORETTI, 1950, p. 393). O comportamento de Zeno em si é muito "suspeito", conseqüentemente, não podemos acreditar que encontraremos no relato uma verdade absoluta. Esta dificilmente figurará em sua vida. Diante disso, preferimos falar em hipóteses e não em "verdades" ou afirmações categóricas, uma vez que o posicionamento narrativo do protagonista não nos permite.

Zeno não nega recorrer à mentira, confessando em várias passagens fazer uso da mesma. Tomemos, como exemplo, uma passagem em que ele mente ao amigo Túlio, quando indagado se trabalhava:

Perguntou-me se eu trabalhava. Todos por aí diziam que eu não fazia nada e temi que ele me invejasse num momento em que eu tinha necessidade de comiseração. Menti! Contei-lhe que trabalhava em meu escritório, não muito, mas pelo menos seis horas por dia e que, além disso, os negócios muito embrulhados que herdara de meu pai e de minha mãe davam-me o que fazer por outras seis horas. ${ }^{12}$ (SVEVO, 2006, p.107)

Assim como o amigo Túlio, a esposa, Augusta, demonstra saber das mentiras do marido. Ela e as irmãs tinham consciência de que as histórias "aventureiras", contadas por Zeno, não passavam de fantasias, frutos de sua imaginação. Vejamos a passagem em que isso fica evidente:

Muito tempo depois soube por Augusta que nenhuma das três moças levava a sério as minhas narrativas. Isso, para Augusta, as fazia mais preciosas, pois, se inventadas por mim, tornavam-se 
ainda mais pessoais do que se fosse o destino que mas houvesse imposto. (...) A única que se indignava com minhas mentiras era a circunspecta Ada. ${ }^{13}$ (SVEVO, 2006, p.88)

A visão de Zeno não nos parece muito confiável, de antemão. Os contornos de seu eu delineiam-se paulatinamente por traços informes e borrados. A problemática em torno de uma identidade plausível para nosso narrador inicia-se, pode-se dizer, na própria estrutura da narrativa. Zeno, já maduro, volta ao passado como mais uma tentativa de buscar a cura. A "viagem" em busca de si mesmo parte da maturidade, passando por várias fases de sua existência. Presente e passado misturam-se, confundem-se e fundem-se, às vezes. No momento em que este Zeno "velho" resolve debruçar-se sobre seu passado, recontando-o e lançando olhares sobre o Zeno jovem, alvo da narração, ele reconstrói sua vida.

$\mathrm{O}$ romance não apresenta um tempo linear, cronológico dos acontecimentos. Na verdade, são os acontecimentos vividos por Zeno que exprimem a noção temporal, já que temos uma narrativa dividida por temas, encarregados de nomear os capítulos: "O fumo", "A morte de meu pai", "A história de meu casamento", "A mulher e a amante", "História de uma sociedade comercial" e "Psicanálise". O tempo no romance, de acordo com Teresa de Lauretis, não existe sem os acontecimentos, os quais são a fictícia realidade da narrativa ${ }^{14}$ (LAURETIS, 1976, p.64, tradução nossa).

Zeno "velho" irá contar um pouco de sua história: o vício pelo fumo iniciado na infância, a morte do pai, o casamento, o adultério, a sociedade com o cunhado e a sua "efetiva" cura. Assim podemos perceber, a princípio e bem explicitados, dois Zenos, um narrador e outro narrado, um que olha e o outro que é alvo desse olhar.

Segundo Aguiar e Silva, entre eu narrador e eu narrado, pode-se abrir uma distância temporal grande, determinante em cravar outros tipos de distâncias, entre elas, psicológica, ideológica e/ou ética. Ele ressalta ainda que o eu narrador, ao voltar a seu passado, e depararse com seu eu narrado, pode assumir uma postura irônica, solidária ou "julgadora", pois $o$ 
fluir do tempo esgarça a identidade entre o eu narrador e o eu narrado, instaurando entre ambos uma relação ambígua e complexa de continuidade e ruptura (AGUIAR E SILVA, 1983, p.770).

Resultante de uma narrativa, que traz consigo a marca do duplo, Zeno parece fadado à dualidade, à fragmentação de seu eu, que se divide, procurando "viver" em harmonia. Entre o eu-narrador e eu-narrado, abre-se um “abismo". Zeno narrador busca em Zeno narrado o que ele foi, ou o que pretendia ser, contudo, em determinados momentos, o narrador parece não se identificar com aquele que foi no passado.

Tal "estranhamento" de si próprio parece intrínseco à essência de nosso protagonista, cujo nome já porta esse sentimento. Zeno, cujo nome de família é Cosini ("coisinha”, "objeto insignificante”), é foneticamente próximo do italiano zero, e etimologicamente mais próximo ainda de zeno, o estrangeiro ou alienígena (BROMBERT, 2001, p.87). Tal sentido vem confirmado pelo próprio Zeno em um comentário acerca do seu nome começar pela letra "Z”, quando "revive" o encantamento sentido ao saber que as quatro filhas do futuro sogro tinham em comum a inicial "A" dos nomes. Vejamos:

Não demorei muito a perceber que na mesa do Tergesteo, onde se divertia em se mostrar tal qual era, e até um tanto pior, Giovanni Malfenti se impunha uma reserva: nunca falava de sua vida particular ou, quando forçado a isso, só o fazia de maneira discreta, numa voz um pouco mais suave que a habitual. Nutria grande respeito pela família e talvez considerasse que nem todos os que se sentavam naquela mesa fossem dignos de suas confidências. O máximo que ali conseguiu saber a seu respeito é que as quatro filhas tinham nomes com a inicial "A", coisa, segundo ele, vantajosamente prática, pois todas as peças de roupa e objetos com aquela inicial podiam passar de uma filha a outra, sem necessidade de qualquer alteração. Chamavam-se (logo retive de cor os nomes): Ada, Augusta, Alberta e Anna. À mesa dizia-se ainda que todas eram muito bonitas. Essa inicial impressionou-me bem mais do que seria admissível. Sonhava com aquelas jovens atadas uma às outras pelo nome, como mercadoria a ser vendida por atacado. A inicial lembrava algo mais: como me chamo Zeno, tinha a impressão de que, se me quisesse casar, só no estrangeiro poderia encontrar uma mulher cujo nome começasse por " $Z$ ". ${ }^{15}$ (SVEVO, 2006, p.74, grifo nosso)

Zeno sente-se diferente, tem dificuldades para se enquadrar no meio em que vive. Seu sentimento de "estrangeiro" parece extrapolar as fronteiras do próprio eu. Estrangeiro em seu 
próprio país, Zeno sente-se sufocado, e com medo de seus compatriotas. Tal sensação aflora na ocasião de sua lua de mel, vejamos:

Nosso longo caminho através da Itália, apesar da minha nova disposição, não foi isento de infortúnios. Tínhamos viajado sem cartas de recomendação e, não raro, pareceu-me que os estranhos ao redor fossem nossos inimigos. Embora ridículo, não consegui superar esse temor. Podia ser assaltado, insultado ou principalmente caluniado - quem iria proteger-me?

Houve mesmo um momento em que senti uma verdadeira crise de medo, da qual por sorte ninguém se apercebeu, nem mesmo Augusta. Costumava pegar todos os jornais que me ofereciam na rua. Parando um dia diante de uma banca, veio-me o temor de que o jornaleiro, por ódio, me acusasse de roubo, já que eu comprara dele apenas um jornal, tendo vários outros embaixo do braço, adquiridos pelo caminho e nem sequer abertos. Corri célere dali, seguido por Augusta, a quem não revelei a razão de minha pressa. ${ }^{16}$ (SVEVO, 2006, p.161)

Esse tipo de "estranhamento" é encontrado também no próprio idioma de nosso protagonista, que se sente "excluído" por não falar a "língua oficial" de seu país. Confinado a comunicar-se pelo dialeto triestino, ele trará consigo a sensação de ser estrangeiro e, acima de tudo, a impressão de que aquilo que for enunciado por ele não poderá ser verdadeiro. Vejamos:

O doutor confia tanto nas minhas benditas confissões que não quer nem mesmo devolvê-las para que as reveja. Meu Deus! Ele só estudou medicina; por isso não sabe o que significa escrever em italiano para nós que falamos (e não sabemos escrever) o dialeto. Uma confissão escrita é sempre mentirosa. Mentimos em cada palavra toscana que dizemos! Podemos falar com naturalidade das coisas para as quais temos frases prontas, mas evitamos tudo quanto nos obrigue a recorrer ao dicionário! Dessa mesma forma, escolhemos de nossa vida os episódios mais notáveis. Compreende-se que ela teria uma feição totalmente diversa se fosse narrada em dialeto. ${ }^{17}$ (SVEVO, 2006, p.391)

A sensação de não pertencer à própria pátria, de não se identificar com esta deve-se, em partes, como já vimos, pela localização geográfica e posição histórica da Trieste cosmopolita em que Zeno nasceu. Para Spagnoletti, tal cidade assemelha-se a uma "caldeira" na qual se misturavam e se debatiam, ou viviam com desconfiança, eslavos, alemães, italianos e exilados políticos de toda parte da Europa $^{18}$ (SPAGNOLETTI, 1991, p.9, tradução nossa). 
Trieste, no período que compreende a segunda metade do século XIX e início do século XX, era uma cidade em crescente progresso, com significativo incremento de atividades ligadas ao comércio, em que a iluminista fé no trabalho conduzia o desejo, a sede de prosperidade de uma classe em proeminente ascensão, ou seja, a burguesia. Entre o período de 1900 a 1910, sua população subiu de 176 mil para 235 mil habitantes, sendo que 5\% desse total eram alemães. A cidade tornou-se, segundo Elio Apih, um dos mais importantes centros mundiais de navegação a vapor e de comércio de café (APIH, 1988, p.25).

De acordo com Bon, uma das principais e mais marcantes características de Trieste era o dinamismo conseqüente da presença de um porto que recebia navios de diversas nações, sendo "habitado" por uma verdadeira babel de línguas estrangeiras que se juntava ao triestino, dialeto local, ao italiano acadêmico das classes cultas e ao alemão (BON, 1977, p.5).

É nesse ambiente múltiplo que Zeno crescerá, acompanhado pela sensação de ser um estrangeiro em sua própria terra e, principalmente, sentindo-se um verdadeiro estranho para si mesmo. Essa sensação de não se reconhecer, aparece ainda, em outros momentos, travestida em um tom de zombaria do passado, ornada por uma postura irônica em relação ao que ele viveu. A senilidade parece alterar a maneira como nosso protagonista olha para a vida, pintada, por ele, com tintas mais leves, menos angustiantes. Vejamos uma fala de Zeno que demonstra isso e evidencia, ainda, a aceitação do vício pelo fumo:

Minhas resoluções são agora menos drásticas e, à medida que envelheço, torno-me mais indulgente para com minhas fraquezas. Ao envelhecermos, sorrimos da vida e de todo o seu conteúdo. Posso assim dizer que, desde há algum tempo, tenho fumado muitos cigarros... que não serão os últimos. ${ }^{19}$ (SVEVO, 2006, p.19)

Determinadas lembranças levam Zeno narrador a se questionar se ele e Zeno narrado são a mesma pessoa; o eu-narrador já não se reconhece na figura do eu-narrado. Por vezes, o senhor Cosini demonstra sentir vergonha de si próprio e de seu passado. O fulminante "amor" 
que ele teve por Ada, sua cunhada, constitui-se em um bom exemplo desse estranhamento de si próprio. Vejamos:

É-me penoso relatar meu namoro com Ada. Passei mais tarde por um período interminável de minha vida em que me esforçava por esquecer aquela estúpida aventura de que me envergonhava a ponto de protestar. "Mas aquele idiota era mesmo eu?!" Quem havia de ser! Como o protesto confere sempre algum conforto, eu insistia. $\mathrm{O}$ caso não teria tanta importância se tivesse ocorrido dez anos antes, quando eu estava com vinte! Mas ser punido com tamanha imbecilidade só pelo fato de que havia resolvido casar-me é algo que me parece injusto. Eu, que já tinha passado por toda espécie de aventura, guiado sempre por um espírito resoluto que chegava inclusive à desfaçatez, eis que de repente me transformava no rapazinho tímido que procura aflorar a mão da bem-amada, de preferência sem que ela perceba, para depois adorar aquela parte do próprio corpo que teve a glória de um tal contato. Essa aventura, que foi a mais cândida de minha vida, até hoje, já velho, recordo-a como se fosse a mais torpe. Era fora de propósito, deslocada no tempo, como um rapaz de dez anos que ainda se aferra ao seio de sua ama. Uma vergonha! $!^{20}$ (SVEVO, 2006, p.86, grifo nosso)

Observador crítico de si mesmo e dos outros, Zeno narrador fixa, de acordo com Wladimir Krysinski, um tipo de sistema de auto-regulamento analítico, discursivo e narrativo que lhe permite simultaneamente confessar e relativizar a confissão ${ }^{21}$ (KRYSINSKI, 1995, p.160, tradução nossa). Assim, logo após narrar alguma proeza de seu passado, nosso narrador irá tecer comentários, fazer ressalvas sobre o que foi dito por ele, deixando-nos reticentes acerca da veracidade dos fatos. Tal pressuposto pode ser notado na observação que ele faz logo após ter confessado sentir-se um idiota em relação ao suposto amor sentido pela cunhada. Vejamos:

Devo dizer que de certa forma eu não me comportava exatamente como um colegial enamorado que se cala à espera de que a bem-amada lhe salte ao pescoço. Nada disso. Eu queria declararme, só que mais tarde. Esperava tornar-me um pouco mais nobre, mais forte, mais digno da minha divina eleita. Isso poderia acontecer de um momento para outro. Por que não esperar? ${ }^{22}$ (SVEVO, 2006, p.87)

A impressão que temos é a de estar diante de duas vozes contrárias que estabelecem entre si uma relação de subordinação. A voz do narrador depende da voz do personagem, alvo da narração, e vice-versa, a concretização de uma pressupõe a concretização da outra. Segundo Cristiane Miorin, a reflexividade criada pelo discurso joga narrador e personagem numa relação dúplice, na qual o desejo desta torna-se a glória daquele (MIORIN, 2006, 
p.54). Miorin atribui a essa oposição entre as vozes do discurso a modernidade da narrativa sveviana. De acordo com a mesma, a cisão entre essas duas instâncias cria a cisão da personagem que se torna a alegoria da fragmentação moderna do indivíduo (MIORIN, 2006, p.54).

Diante disso, deparamo-nos com um homem que parece viver "em constante crise" consigo mesmo. Um sujeito que busca um lugar ao sol, já sem certezas, perdido entre o que ele foi e o que ele é, entre o que ele quer e/ou pretende ser e o que ele, de fato, aparentará ser. Nesse contexto, as relações familiares serão importantes por desnudar um pouco de sua essência, bem como a "aparência" que ele procura demonstrar a seus entes. 


\subsection{RETRATO DE UMA FAMÍLIA BURGUESA, RELAÇÕES}

\section{EM JOGO!}

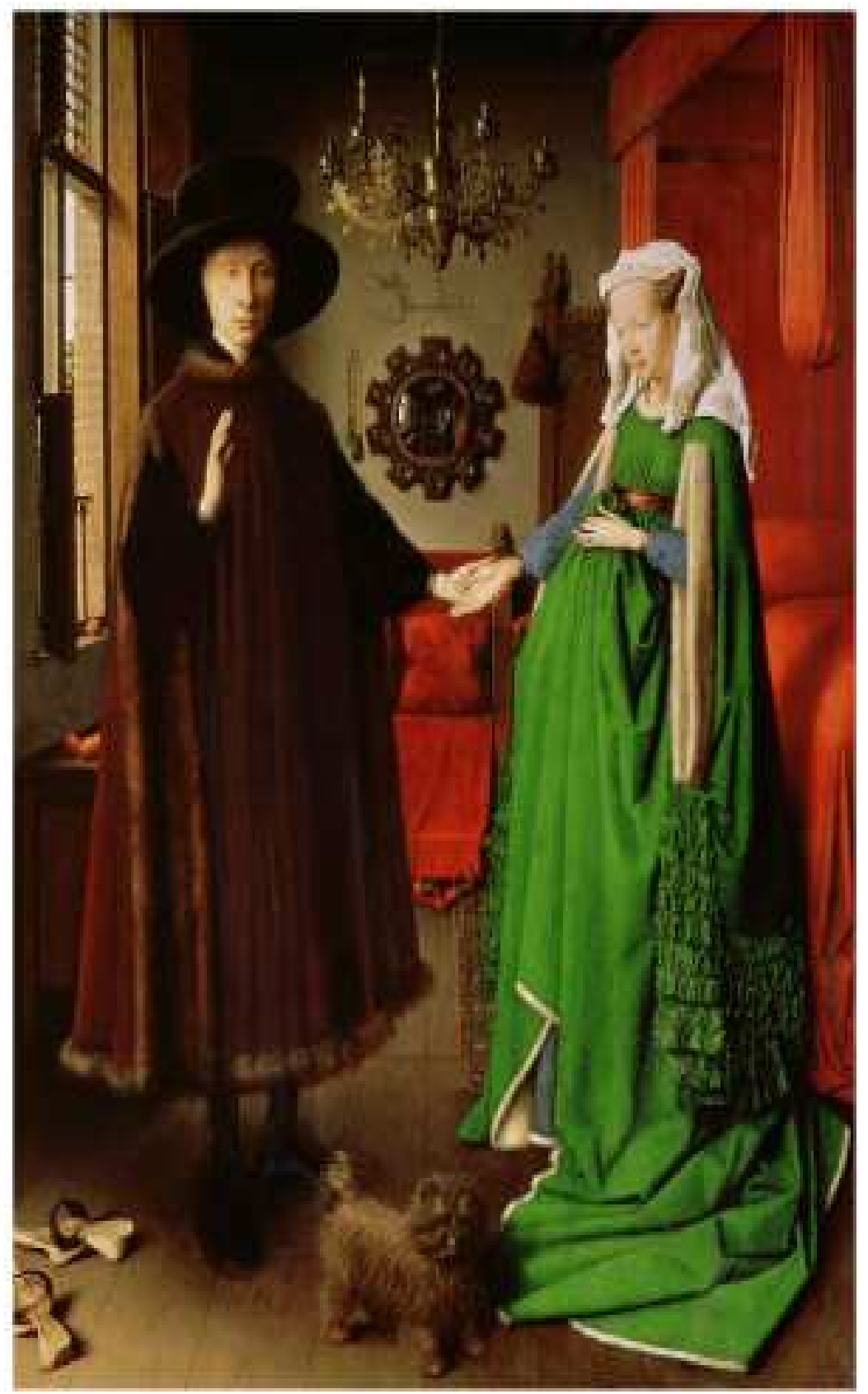

The Portrait of Giovanni Arnolfini and his wife Giovanna Cenami (1434) Jan Van Eyck 
Casamento: Uma comunidade que consiste em um homem, uma mulher e um(a) amante, num total de duas pessoas.

Ambrose Bierce

De todas as coisas sérias o casamento é a mais cômica.

Pierre Beaumarchais

A movimentação de nosso protagonista no ambiente familiar é de grande importância para caracterizá-lo e, de certa forma, individualizá-lo enquanto filho, esposo "fiel” perante a mulher e a sociedade, pai, cunhado, genro, enfim, como um burguês abastado, "confiável" e "bem visto" aos olhos da sociedade da qual ele é integrante.

Podemos dizer que A consciência de Zeno constitui-se em um romance de família, conforme classificação do crítico Sandro Maxia, pois temos em cena as relações humanas mais elementares, isto é, as relações de parentesco ${ }^{23}$ (Maxia, 1990, p.38, tradução nossa).

Mais que um "romance de família", A consciência de Zeno nos apresenta uma pintura fiel ao modo de vida da elite européia do início do século XX, trazendo à tona tradições, costumes e vícios.

Oretta Guidi, no artigo Il matrimonio è in scena, secondo Italo Svevo, disponível para consulta na internet, pelo sítio http://www.repubblicaletteraria.it/ItaloSvevo.html, defende que a temática do matrimônio, regada por represálias, crises, brigas e infidelidade, para citar algumas características, é comum na obra do escritor triestino. Afirma ainda que, para Svevo, o casamento é uma espécie de espelho da sociedade mitteleuropea, da qual ele faz parte, já à deriva, uma vez que perdeu sua centralidade e hegemonia.

A história do matrimônio de Zeno, muito distante dos belos contos e poemas de amor, beira a uma tragicomédia. Nosso protagonista relata que se casa com Augusta não por amor, mas por conveniência, ou até mesmo por certo "desespero", uma vez que se frustrara duplamente ao ter o pedido de casamento negado pelas outras duas irmãs, Ada e Alberta. 
Desconsolado e movido por certa angústia, nosso narrador, sem "alternativas", na mesma noite, termina por pedir a mão de Augusta, que, sabendo do "amor" deste por sua irmã Ada, pergunta-lhe: - Devo então saber e recordar sempre que você não tem amor por mim $?^{24}$ (SVEVO, 2006, p.136). Zeno responde com certa arrogância e descaso, como se estivesse fazendo um favor a Augusta: - É certo. Amo apenas Ada, mas me casarei com voce... ${ }^{25}$ (SVEVO, 2006, p.137). Augusta, vislumbrando na figura de Zeno uma oportunidade para concretizar seu sonho de casar-se, aceita o pedido: - Zeno, você precisa de uma mulher que queira viver a seu lado e tome conta de você. Hei de ser essa mulher ${ }^{26}$ (SVEVO, 2006, p.137). Nessas circunstâncias, dá-se o casamento às avessas, por assim dizer, ou aventura matrimonial $^{27}$ (SVEVO, 2006, p.68), como nosso próprio Zeno intitula.

Seu matrimônio, com a "feia" Augusta, segundo a descrição que ele faz, é de suma importância no circuito de suas "memórias". Tal casamento, imprescindível como mais um meio de entendermos e conhecermos nosso protagonista, é relevante, também, por ilustrar a "movimentação" de uma classe social sempre voltada ao econômico. Durante a lua-de-mel, o comportamento do casal Cosini já aponta para um mundo em ascensão, regido pelo consumismo, impulsionado pela crescente e intensa evolução e fixação do capitalismo como sistema econômico. De acordo com Zeno, após as visitas a museus, começaram as entediantes compras da esposa. Augusta realiza vultosos gastos em todas as cidades visitadas durante a viagem de núpcias. Para ela, tais aquisições eram sólidos investimentos. Vejamos como o narrador relata esse acontecimento, fundamental para "fixar" uma idéia do estilo de vida do casal:

A saúde impele à atividade e à aceitação de um mundo de enfados. Após os museus, começaram as compras. Augusta, antes de nela morar, conhecia a nossa casa melhor que eu e sabia que num quarto faltava um espelho, que outro precisava de um tapete, que num terceiro havia um lugar ideal para um bibelô. Comprei móveis para um salão inteiro e, de todas as cidades em que pernoitamos, sempre expedíamos alguma coisa para casa. Eu era de opinião que teria sido mais oportuno e menos dispendioso adquirir todas aquelas coisas em Trieste. Agora tínhamos que cuidar da remessa, do seguro e da liberação alfandegária. ${ }^{28}$ (SVEVO, 2006, p.160) 
Os excessivos gastos parecem não incomodar o burguês recém-casado que desfruta de boa situação financeira. A união do casal que se dá de maneira intrigante, uma espécie de conto de fadas às avessas, termina por trazer vantagens à vida de Zeno. Ao longo da enunciação das "memórias", podemos notar que ele, de certa forma, favorecido pela sorte (DEBENEDETTI, 1995, p.80), termina por fazer um bom negócio ao casar-se com a mais "feia" das irmãs Malfenti. Augusta trará mais conforto e benefícios à vida do marido, vejamos:

De regresso da viagem de núpcias, tive a surpresa de morar numa casa que nunca fora tão
cômoda e acolhedora. Augusta introduziu nela todos os confortos que havia na sua própria, além
de muitos outros que inventou. O quarto de banho que na minha memória de homem sempre
esteve ao fundo do corredor, a meio quilômetro do quarto de dormir, transferiu-se para o lado do
quarto do casal e foi provido de um número maior de torneiras e pias. Um quartinho junto à sala
de jantar foi convertido numa pequena sala íntima para o café. Coberta de tapetes e dotada de
grandes poltronas forradas de couro, ali ficávamos a conversar todos os dias por uma boa hora
após as refeições. Contra o meu desejo, havia ali todo o necessário para fumar. Até o meu
pequeno estúdio, embora eu proibisse, sofreu algumas modificações. Temia que as alterações o
tornassem odioso; logo, porém, percebi que só então se fizera habitável. Augusta dispôs a
iluminação de modo a que eu pudesse ler sentado à mesa, refestelado na poltrona ou reclinado
sofre o sofá. Para o violino foi providenciada uma estante com uma pequena lâmpada, que
iluminava a partitura sem ferir os olhos do executante. Também ali, e contra a minha vontade,
havia todos os apetrechos necessários para fumar tranqüilamente. ${ }^{29}$ (SVEVO, 2006, p.165, grifo
nosso)

Temos aqui uma pintura nítida de uma casa típica da classe abastada. Note-se que esse "lar" sofre inúmeras modificações em sua estrutura física, até adequar-se totalmente às exigências do jovem casal que vive em meio ao luxo e conforto. A casa é projetada, como vemos, para atender aos desejos e "necessidades" de Zeno. Augusta, esposa preocupada, pensa em todos os detalhes para propiciar ao marido o mais pleno conforto e bem-estar, evidentes, por exemplo, na disposição de todos os apetrechos necessários para Zeno fumar tranqüilamente $^{30}$ (SVEVO, 2006, p.165). Ações como estas demonstram que Augusta parece conhecer mais o marido do que ele próprio. Ainda que este diga não aprovar tais mudanças, sabemos que as aprecia e demonstra, pela narrativa, que "inconscientemente" as deseja ardentemente. 
O matrimônio com Augusta, que parecia fadado ao fracasso e à infelicidade dos noivos, constitui-se em uma relação tranqüila, estável e proveitosa para ambos. Augusta revela-se uma esposa afetuosa, amável e extremamente preocupada com o marido. Com o enlace, ela conquista uma vida regada por luxos, belas roupas e jóias e, principalmente, alcança a concretização de um sonho que lhe parecia distante e até impossível, o casamento.

O casal compõe uma família nos moldes do patriarcalismo em que o homem apresenta-se como soberano, representante máximo de seu "reino", e a mulher, aparentemente submissa às suas vontades, por vezes, não tem autonomia, vida própria, uma vez que parece viver exclusivamente para satisfazer os desejos e desmandos do esposo. Vejamos uma passagem que denota a aparente submissão de Augusta:

Lembro-me, na primeira fase, que Augusta se mostrava plenamente satisfeita comigo. Quando não a agarrava, tornava-me de uma loquacidade extraordinária. Era uma necessidade. Para justificá-la, meti na cabeça a idéia de que, tendo de esposar Augusta, devia igualmente empreender sua educação. Educava-a para a doçura, o afeto e, sobretudo, para a fidelidade. Não me recordo exatamente da forma que dava às minhas prédicas, das quais uma delas me foi evocada por Augusta, que nunca as esqueceu. Ouvia-me atenta e submissa. Eu, uma vez, no ardor da eloquiência, proclamei que, se um dia ela descobrisse uma traição minha, isto lhe daria o direito de pagar-me na mesma moeda. Ela, indignada, protestou que seria incapaz de trair-me nem mesmo com minha permissão e que, diante da minha infidelidade, só lhe caberia o direito de chorar. ${ }^{31}$ (SVEVO, 2006, pp.149-50, grifo nosso).

Augusta, pode-se dizer, constitui-se, pela representação fornecida por Zeno, na personificação dos valores e da ética burguesa de sua época. Ela representa a mulher, a mãe, a esposa em uma sociedade que a ignora, que aniquila seus anseios e suas vontades, que nega seu direito de fala, uma sociedade, enfim, dominada e governada pelo machismo e autoritarismo do homem. O comportamento de Augusta não nega tais pressupostos, sua vida parece estar intrinsecamente ligada à existência do marido. Isso fica evidente na seguinte passagem:

Um dia, logo após essa viagem de núpcias, deixei-me inocentemente persuadir de não ir almoçar em casa; após ter comido qualquer coisa num bar, fiquei na rua até a noite. Quando regressei, já à hora do jantar, encontrei Augusta à minha espera, quase morta de fome, pois não havia almoçado. Não me dirigiu qualquer censura, mas não se deixou convencer de que agira mal por me esperar. Suavemente, embora com firmeza, declarou que, como não a havia prevenido, teria esperado por mim para o almoço até a hora do jantar. E não foi por brincadeira! Outra vez, ao 
me deixar conduzir por um amigo e ficar fora de casa até as duas da manhã, deparei-me com Augusta à minha espera, batendo os dentes de frio, pois a estufa se apagara. ${ }^{32}$ (SVEVO, 2006, p.166)

Ela é a "encarnação", por assim dizer, de uma verdadeira dama da sociedade burguesa italiana, sendo apresentada pelo marido, por diversas vezes, de maneira depreciativa. Fisicamente ela é, de acordo com a descrição feita pelo próprio esposo, gorda, dona de certa feiúra, e, ainda, possui uma cabeleira rala:

Eis que das quatro jovens com a mesma inicial uma para mim já não contava [Augusta]. Como tiveram coragem de achá-la bonita? A primeira coisa que se notava nela era o estrabismo tão pronunciado que, evocando-a mais tarde, conseguia personificá-la toda. Os cabelos, não muito abundantes, eram louros, de um tom esmaecido, isento de luz, e o corpo, embora interessante, era um pouco gordo demais para a idade. Nos poucos instantes que estive só, pensei: "Se as outras são parecidas com esta!...." 33 (SVEVO, 2006, p.76)

Recordei que, ao ver Augusta pela primeira vez, fui surpreendido pela feiúra, visto que estava na expectativa de que as quatro moças de inicial "A" daquela casa fossem todas belíssimas. Sabia agora que me amava desde há muitos, mas o que provava isto? Não lhe dei a satisfação de desmentir-me: quando eu morresse, ela se casaria com outro. Mitigado o pranto, apoiou-se mais em mim, de súbito, sorrindo, perguntou:

- Onde encontraria o seu sucessor? Não vê como sou feia? ${ }^{34}$ (SVEVO, 2006, p.164)

Note-se, no segundo trecho, que a própria Augusta, através do que o seu marido nos relata, caracteriza-se como feia, um obstáculo, conforme a mesma, para despertar o interesse de um homem. A sua descrição psicológica chega a ser ainda mais mesquinha e cruel, já que esta é reduzida a um ser "dependente", sem personalidade, cujo único interesse na vida seria o de adivinhar os pensamentos e desejos do marido, para em seguida satisfazê-los. Observemos a destrutiva referência de Zeno à esposa e ao amor que ela lhe dedica:

Que importância atribuía ela a mim em seu pequeno mundo! Devia manifestar meu desejo a propósito de tudo, na escolha dos alimentos ou das roupas, das companhias ou das leituras. Era obrigado a uma grande atividade que não me aborrecia. Colaborava para a constituição de uma família patriarcal e eu próprio me tornava o patriarca que no passado odiei e que agora me surgia como símbolo da saúde. Uma coisa é sermos o patriarca; outra bem diferente é venerar alguém que se arroga tal dignidade. Queria a saúde para mim à custa de atribuir a doença aos não-patriarcas, e especialmente durante a viagem aconteceu-me assumir por vezes de bom grado uma atitude de estátua eqüestre. ${ }^{35}$ (SVEVO, 2006, p.159) 
Nessa passagem, Zeno afirma e salienta que o verdadeiro papel de Augusta na sociedade matrimonial que constituíram é o de viver exclusivamente para servi-lo. Nosso protagonista, no fundo, tem consciência de que precisa da esposa para sentir-se saudável, sem esta ele parece perder o rumo, ficar perdido. Contudo, seu orgulho não o deixa admitir, explicitamente, a verdadeira importância de Augusta.

Na verdade, nosso "herói” precisava sentir-se superior a alguém, uma vez que diz ser tão fraco e incapaz. Esse sentimento de superioridade é buscado por Zeno, aqui, com a "cruel” inferiorização da mulher. O senhor Cosini procura diminuir a esposa talvez impulsionado por certa inveja, uma vez que ela em seu pequeno mundinho demonstra ser uma mulher realizada, feliz e sã. Ele, ao contrário, sente-se frustrado, infeliz e doente. Daí a necessidade de aniquilar aqueles que se encontram à sua volta, em especial, a própria esposa, a única que conseguirá impor um pouco de felicidade e saúde à sua existência.

No entanto, nosso narrador não conseguirá se impor à figura de seu cunhado, o senhor Guido Speier. Zeno sentir-se-á diminuído diante deste, cuja descrição pode ser comparada a de um príncipe, ou, até mesmo, um destemido e belo herói da época medieval. As características físicas do senhor Speier parecem incomodar e ofuscar Zeno:

Fitava-o para compreender melhor o que dizia. Era um rapaz de muito boa aparência: os lábios naturalmente entreabertos deixavam ver uma boca de dentes brancos e perfeitos. Seus olhos eram vivazes e expressivos e, quando tirou o chapéu, pude ver que seus cabelos escuros e um pouco anelados cobriam todo o espaço que a mãe natureza lhes havia destinado, ao passo que uma boa parte da minha cabeça já fora invadida pela fronte. ${ }^{36}$ (SVEVO, 2006, pp.111-2)

Aqui temos ressaltada a beleza de Guido em contraposição à promissora calvície de Zeno. O senhor Speier, que por vezes demonstrará certa agressividade e inveja pelo cunhado, servir-se-á dessa característica para assim ridicularizá-lo em duas caricaturas. Nestas, o comportamento agressivo de Guido evidencia-se. Guido parece incomodar-se, sentir-se irritado com a aparente calma de Zeno, que, mesmo destituído de beleza física, consegue 
vencer todas as suas batalhas, conquistar estabilidade financeira e constituir uma família harmoniosa. Guido, diferentemente, revelar-se-á o verdadeiro perdedor da história, dando fim à sua "vida" de maneira estúpida. Vejamos o trecho em que Guido recorre às caricaturas para tentar desestabilizar o "equilíbrio" do cunhado:

[Guido]... fez duas caricaturas minhas. Na primeira, representava-me com o nariz para o ar, apoiado no cabo de um guarda-chuva espetado à terra. Na segunda, o guarda-chuva se havia partido e o cabo me penetrara pela espinha. As duas caricaturas atingiam o escopo de causar hilaridade mediante o artifício banal de manter o indivíduo que me devia representar - na verdade, bastante semelhante a mim, embora caracterizado por uma extensa calva absolutamente imperturbável em ambos os desenhos, decorrendo daí que minha distração era tanta a ponto de não mudar de aspecto, não obstante trespassado pelo guarda-chuva. ${ }^{37}$ (SVEVO, 2006, p.139)

Diante do cômico desenho, todos riram muito, até demais, conforme palavras do próprio Zeno, atingido por uma dor lancinante ${ }^{38}$ (SVEVO, 2006, p.139), amenizada pela atitude da doce e fiel Augusta. Vejamos:

Encontrei uma aliada em Augusta. Pediu-me que pusesse à margem de meu desenho a data de nosso noivado porque também ela queria guardar a garatuja. Uma cálida onda de sangue inundou as minhas veias graças a essa demonstração de afeto; pela primeira vez reconheci o quanto era importante para mim $^{39}$ (SVEVO, 2006, p.140, grifo nosso).

Zeno começa a ter certa consciência da importância de Augusta para sua vida. Mais que uma formiga assídua ${ }^{40}$ (SVEVO, 2006, p.209) a cuidar do lar e da família ou uma sadia ama de leite ${ }^{41}$ (SVEVO, 2006, p.248) ela constituir-se-á para ele, como bem notou em seu trabalho Maria Celeste Tommasello Ramos, um perfeito instrumento para seu próprio bem estar (RAMOS, 2001, p.162).

Nosso protagonista, à medida que nos conta sua história, parece descobrir certa beleza na esposa, já vista sob um olhar diferente. Esta era muito menos feia do que eu imaginava, e descobri sua maior beleza quando a beijava: o rubor! ${ }^{42}$ (SVEVO, 2006, p.149). A categórica afirmação de que amava somente Ada, também, é vista com outros olhos. 
Confuso, ele se questionará, inúmeras vezes, se, de fato, não sente amor por Augusta: - Será que a amo? Trata-se de uma dúvida que me acompanhou por toda a vida, até hoje posso pensar que o amor eivado de tanta dúvida é o verdadeiro amor ${ }^{43}$ (SVEVO, 2006, p.142). Zeno, em determinados momentos, chega a declarar que ama a esposa, contudo, logo em seguida, esse "amor" é colocado na berlinda, visto como algo efêmero, vejamos:

Em minha vida houve vários períodos em que me acreditei no caminho da saúde e da felicidade. Contudo, tal crença nunca foi tão forte quanto por ocasião da viagem de núpcias e das semanas que se seguiram ao nosso retorno. Começou com uma descoberta que me surpreendeu: eu amava Augusta como ela a mim. Desconfiado a princípio, desfrutava a felicidade de um dia, sempre na suposição de que tudo mudaria no seguinte. Contudo, uns se seguiam aos outros, semelhantes todos, luminosos, em que perdurava a amabilidade de Augusta e - eis a surpresa - a minha! A cada manhã encontrava nela o mesmo afeto comovido e em mim o mesmo reconhecimento que, se não era amor, se lhe assemelhava muito. Quem haveria de prevê-lo, quando andei saltitando de Ada para Alberta e desta para Augusta? Descobri que não fora um paspalho cego, guiado pelos outros, mas pessoa habilíssima. ${ }^{44}$ (SVEVO, 2006, p.157, grifo nosso)

Zeno aqui parece desnudar-se um pouco mais de suas máscaras e mostrar-se como realmente é, ou seja, um narrador habilidoso, esperto, sagaz, que consegue tirar proveito de situações que pareciam totalmente fadadas ao fracasso. A esse propósito, a escolha da esposa certa, bem como a riqueza que ele acumula ao agir por conta própria, em meio à guerra, constituem-se em bons exemplos de seu caráter ardiloso.

Sabemos que o sentimento que Zeno alimenta pela mulher está longe de se constituir em um "amor verdadeiro", ou "ágape”, de acordo com a denominação de Ramos (RAMOS, 2001, p.167). Seu ego não lhe permite a entrega e a vivência de um sentimento mais sublime. Além do mais, não podemos nos esquecer de que esse narrador relata a história de sua vida, do cotidiano vivido, sendo este permeado por momentos bons e ruins, de vitórias e derrotas. Dessa forma, o sentimento pintado por ele parece alinhar-se melhor à sua realidade que não permitiria espaço, abertura para a vivência de um amor idealizado, "perfeito", como aquele descrito nos poemas ou contos de fadas, muito belo, contudo irreal e incoerente com suas memórias. Assim, ao invés de amor, preferimos dizer que Zeno termina por sentir-se grato, preenchido com o bem-estar que a esposa traz à sua "vazia" existência. 
Seu casamento, na verdade, alicerça-se em conveniências, para ambas as partes. Aos olhos da sociedade é, ou melhor, deve parecer uma instituição sólida, respeitosa e feliz. Sabemos, porém, pela instância narrativa, que Zeno casa-se com Augusta não por escolha, mas por falta de opção.

Zeno sabe vestir, perfeitamente, a "máscara" de esposo fiel e zeloso que retribui o carinho recebido da esposa, com agrados e mimos materiais. Todavia, como ele próprio afirma viver numa simulação de atividade ${ }^{45}$ (SVEVO, 2006, p.170), o tédio o conduziu ao adultério com uma bela jovem, chamada Carla. Para justificar a traição, Zeno diz em várias passagens ter sido induzido a cometer o adultério, vejamos:

Ela decidiu imediatamente; agarrou-me a mão para forçar-me a entrar. A emoção obscureceume a vista e admito que tenha sido provocada não pelo doce contato da mão, mas por aquela familiaridade que me pareceu decisiva do meu destino e do de Augusta. Ainda assim, creio ter entrado com certa relutância e, quando reevoco a história de minha primeira traição, tenho o sentimento de que só procedi desse modo porque a isso fui induzido. ${ }^{46}$ (SVEVO, 2006, p.185, grifo nosso)

A infidelidade de Zeno, estimulada pelo ócio e inatividade, tem início a partir de sua relação com Copler, um sujeito acometido de nefrite, enfim, um doente real. Zeno, em contraposição, de acordo com a esposa, seria uma espécie de doente imaginário. Tal premissa fica evidente no seguinte trecho: Augusta pôs-se a rir gostosamente, declarando que eu não passava de um doente imaginário ${ }^{47}$ (SVEVO, 2006, p.171).

A observação de Augusta parece incomodar o doente real, Copler, que replica dizendo preferir a doença real à imaginária, tecendo comentários ferinos à doença de Zeno. Vejamos:

Sobre a face emaciada de Copler passou algo como um ressentimento. Súbito, virilmente, libertou-se do estado de inferioridade a que parecia condenado, acrescentando com grande ênfase:

— Doente imaginário? Pois bem, prefiro ser um doente de verdade. Antes de mais nada, um doente imaginário é uma monstruosidade ridícula; além disso, para ele não existem remédios, ao passo que a farmácia, como se vê por mim, dispõe sempre de alguma coisa eficaz para os verdadeiros doentes.

Suas palavras pareciam as de um homem são e eu - quero ser sincero - sofri com elas ${ }^{48}$ (SVEVO, 2006, p.171). 
Nosso protagonista ressentido e, de certa forma, inferiorizado com as palavras do amigo, sente-se ainda mais doente. Diante disso, Augusta, que desencadeara a "discussão", intervém a favor do marido, revertendo a situação, e suscitando em Copler um sentimento de inferioridade e inveja. Inveja que pode ser vislumbrada, de antemão, na agressividade inicial contra Zeno. Com a intervenção da esposa, Zeno parece voltar ao seu "pedestal”, vejamos:

Por causa da invectiva de Copler, eu mostrava um aspecto verdadeiramente doentio, de doente maltratado. Augusta sentiu necessidade de intervir a meu favor. Acariciando a mão que eu abandonara sobre a mesa, disse que a minha doença não perturbava ninguém e que ela não estava nem mesmo convicta de que me achava enfermo, pois, caso contrário, eu não poderia demonstrar tanta alegria de viver. Com isso, Copler voltou ao estado de inferioridade a que estava condenado. Era inteiramente só no mundo e, se podia lutar contra mim em matéria de saúde, não conseguia contrapor a mim um afeto semelhante ao que Augusta me ofertava. Sentindo a viva necessidade de uma enfermidade, resignou-se a confessar mais tarde o quanto me invejava por isso. ${ }^{49}$ (SVEVO, 2006, p.172)

O pobre Copler, totalmente resignado à sua doença real, deixa de exercer qualquer atividade profissional e passa a se dedicar à filantropia, organizando, para tanto, coleta de dinheiro entre amigos e conhecidos. Por intermédio dessa filantropia, praticada pelo amigo, Zeno conhece Carla Gerco e decide "investir" na carreira artística da bela jovem.

A descrição física que Zeno faz da moça não é arrasadora como a da esposa ou de outras personagens. Carla é jovem, bela, graciosa e, como afirma Zeno, nela tudo soava como palavra de amor $^{50}$ (SVEVO, 2006, p.178). No entanto, as observações quanto a seu suposto talento são desalentadoras e, indiretamente, o narrador afirma que a única vocação da moça, a que lhe cabe nesta sociedade burguesa, é a de ser "a amante", "a outra", aquela que vive um "amor" clandestino, às ocultas, tirando deste algum proveito. Vejamos a passagem em que Zeno a destitui de seu talento para o canto:

Cantou "A Minha Bandeira". De meu macio sofá acompanhava seu canto. Tinha um ardente desejo de admirá-la. Como seria bom descobri-la dotada de talento! Ao contrário, tive a surpresa de ouvir que sua voz, quando cantava, perdia toda musicalidade. O esforço adulterava-a. Carla também não sabia tocar e seu acompanhamento estropiado tornava mais pobre ainda a pobre música. Julguei que estivesse diante de uma escolar e analisei se pelo menos o volume de voz era razoável. Era até abundante! Na estreiteza do ambiente meus tímpanos sofriam. Pensei, para 
poder continuar a encorajá-la, que era apenas uma questão de escola errada. ${ }^{51}$ (SVEVO, 2006, p.179)

Para o crítico italiano Giacomo Debenedetti, Zeno, ao "seduzir” a jovem Carla, deixou-se conduzir pela simulação da filantropia, acreditando, seriamente, ter-se interessado por ela, somente, de modo a lhe oferecer meios para estudar a música, vocação para a qual não tinha talento, conforme palavras do próprio narrador (DEBENEDETTI, 1995, p.102). Para Teresa de Lauretis, a relação com Carla é apresentada como uma prova da virilidade de nosso herói (LAURETIS, 1976, p.48).

A relação amorosa do rico burguês e da pobre jovem teve início com um beijo que selou uma promessa de afeto e sobretudo de assistência ${ }^{52}$ (SVEVO, 2006, p.190). Por intermédio dessa afirmação, podemos comprovar que o relacionamento entre eles era pautado, principalmente pelo interesse financeiro da parte de Carla e sexual de Zeno, que, aparentemente, demonstra sentir remorso e culpa por essa relação extraconjugal, como podemos verificar no seguinte trecho:

Nesse dia à mesa, porém, comecei verdadeiramente a sofrer. Entre mim e Augusta pairava minha aventura, como uma grande sombra fosca que me parecia impossível minha mulher também não a visse. Sentia-me diminuído, culpado e doente, e sentia uma dor ao lado como um reflexo, que revelasse a grande ferida que me ia na consciência. Enquanto fingia comer distraidamente, procurei alívio num férreo propósito: "não volto mais lá", pensei, "ou, se por precaução, tiver que revê-la, será pela última vez". ${ }^{53}$ (SVEVO, 2006, pp.190-1)

Nessa fala, Zeno deixa claro que a mulher só não via o que estava acontecendo porque não queria, uma vez que ele mesmo não estava muito preocupado em ocultar a sua aventura. Zeno aqui parece querer incomodar o sossego da esposa, ele chega a demonstrar certa irritação com a vidinha realizada de rica burguesa de Augusta. Tal comportamento vem reforçar a premissa de que ele demonstra sentir inveja da esposa, por esta conseguir viver de modo "pleno" e harmonioso. 
Para o narrador, o adultério foi importante na medida em que lhe permitiu descobrir certo afeto pela esposa, uma espécie de gratidão, como já ressaltamos, ao bem-estar que ela lhe proporciona. A traição pode ser vista ainda como algo positivo na vida de nosso protagonista, uma vez que a esposa, Augusta, e a amante, Carla, são, de acordo com Teresa de Lauretis, figuras complementares que juntas constituem a mulher ideal de Zeno (mãe + amante) ${ }^{54}$ (LAURETIS, 1976, p.60, tradução nossa).

Seu casamento, no entanto, não chega a ser abalado por essa relação extraconjugal. Zeno "parece" ocultar muito bem seu deslize, ao contrário de Guido, que traiu Ada com uma empregada em sua própria casa, sob os olhos da própria mulher. O comportamento do cunhado é condenado impiedosamente por Zeno, como podemos comprovar nesta sua fala: Grande safado! Manchar assim o próprio lar! ${ }^{55}$ (SVEVO, 2006, p.252).

Nosso "herói" posiciona-se, a propósito do acontecido, como se fosse o mais puro e fiel de todos os homens. Para ele, o grande erro de Guido não foi o adultério, mas o fato de este não saber manter as aparências perante a esposa e a sociedade. Zeno não condena a traição, mas a ingenuidade do cunhado ao prevaricar, sob os olhos da esposa, no próprio lar, local "sagrado" da família burguesa. O adultério, por sua vez, é narrado como fato natural nessa sociedade burguesa. Além de Zeno e Guido, a narrativa denota que o pai de Zeno e seu sogro, o senhor Giovanni Malfenti, traíam as esposas. A traição vem pintada como uma característica intrínseca ao sistema social vigente. O próprio Zeno declara isso, vejamos:

Correndo para casa tive até coragem de insurgir-me contra nosso sistema social, como se fosse o culpado de minhas transgressões. Achava eu que ele devia ser suficientemente flexível para permitir que de tempos em tempos (não sempre) se pudesse prevaricar sem temor das conseqüências, mesmo com as mulheres que deveras não amamos. ${ }^{56}$ (SVEVO, 2006, p.212)

Zeno demonstra ter consciência de que mantinha uma relação de poder, bem ao sabor dos valores burgueses, com Carla, mais uma mercadoria adquirida. Nosso protagonista, de acordo com Teresa de Lauretis, tem o controle da situação, estabelecendo uma espécie de jogo em que um "joga" com o outro. (LAURETIS, 1976, p.48). Como regra principal desse 
“jogo", temos a manipulação em que vence aquele que jogar melhor. Zeno manipula por intermédio do dinheiro, importante para concretizar os seus desejos e desmandos; a amante, por sua vez, recorre a uma arma feminina poderosa, o choro.

Nem mesmo o sentimento de culpa, confessado por ele em certos momentos, bastará para colocar um fim em suas aventuras amorosas fora do casamento. Por vezes, Zeno tentará terminar a relação com Carla, mas o mesmo não acontecerá. Assim como a ciranda do último cigarro, ele viverá o eterno propósito da "última traição". A comparação do adultério ao último cigarro, bem como a sensação de culpa, vêm explicitados, por ele mesmo, na seguinte fala:

Posteriormente, quando de fato me tornei amante de Carla, voltando a pensar naquela triste tarde, não cheguei a compreender por que antes de comprometer-me mais a fundo não fui detido por algum propósito mais firme. Tinha lamentado tanto minha traição antes de cometê-la que talvez parecesse ter sido fácil evitá-la. Podemos rir das boas intenções que ocorrem depois do acontecido, como também das que o antecedem, pois não valem de nada. Nas horas angustiosas de então, marquei em grossos caracteres no meu livro de endereços, na letra C (Carla), aquela data com a seguinte nota: "última traiçãa". Mas a primeira traição efetiva, que conduziu a traições ulteriores, só teve lugar no dia seguinte. ${ }^{57}$ (SVEVO, 2006, p.204, grifo nosso)

Assim como o bom propósito de parar de fumar o, também, bom propósito de pôr fim ao adultério nunca chegará, ao menos da parte de Zeno. Sabemos que a "última traição" só se concretizará porque a amante decide casar-se com seu professor de canto, pago pelo próprio Zeno. O último encontro é marcado por momentos de prazer e, sobretudo, por certa "frustração" de Zeno, vejamos:

Foi um instante delicioso. O propósito feito a dois surtia uma eficácia que apagava qualquer culpa. Éramos inocentes e felizes! Meu benévolo destino reservara-me um instante de perfeita felicidade.

Sentia-me tão feliz que continuei a comédia até o momento de nos despedirmos. Não nos veríamos mais! Ela recusou o envelope que eu trazia sempre no bolso do casaco e não quis nem mesmo uma lembrança minha. Era preciso apagar de nossa nova vida os traços dos erros passados. Então beijei-a paternalmente na fronte, como a princípio ela tanto desejara.

Depois, já na escada, tive uma hesitação porque a coisa ia ficando um tanto séria; se tivesse certeza de que ela ainda estaria à minha disposição na manhã seguinte, o pensamento do futuro não me teria ocorrido tão depressa. Ela, do alto do patamar, me via descer e eu, procurando sorrir, gritei-lhe:

-Até amanhã!

Ela recuou surpresa, quase apavorada, e afastou-se dizendo:

-Nunca mais! $!^{58}$ (SVEVO, 2006, pp.250-1) 
Findo o capítulo que narra o caso amoroso com Carla, Zeno passa a relatar a "História de uma sociedade comercial" que integra o penúltimo capítulo do romance. Guido, que se tornara um cunhado "estimado", convida-o a fazer parte da empresa que está formando. Zeno aceita a sociedade para mostrar que é útil e também para provar à sua consciência e a Augusta que não sente mais nada pela cunhada, Ada. Vejamos:

Eu tinha, além disso, outras razões para aceitar a sociedade. Queria ser útil a Guido! Antes de mais nada, queria-lhe bem e, conquanto ele desejasse parecer forte e seguro, para mim não passava de um inerte, carente de proteção, a qual de bom grado eu lhe queria prestar. Ademais, diante de minha consciência, e não só aos olhos de Augusta, parecia-me que, quanto mais me ligasse a Guido, mais clara se patentearia minha absoluta indiferença por Ada. ${ }^{59}$ (SVEVO, 2006, p.267)

Zeno diz ter trabalhado com Guido, durante dois anos, apenas pelo prazer da companhia do cunhado, sem qualquer compensação, contudo isso não é verdade. Ele tenta convencer o leitor, a todo custo, de que estima Guido, de que não guarda rancor por este lhe ter "roubado" a moça que amava, entretanto, seu discurso deixa transparecer certo ressentimento pelo cunhado, conforme sua seguinte declaração: Não queria mal a Guido, mas não seria certamente o amigo que eu teria escolhido livremente ${ }^{60}$ (SVEVO, 2006, p.269).

Zeno, que nunca foi dado ao trabalho, e Guido se esforçam em formar um escritório moderno, inovador, bem diverso dos escritórios triestinos, que cheiram a bacalhau e curtume! $^{61}$ (SVEVO, 2006, p.270). Recusam sugestões e conselhos de comerciantes veteranos, como o pai de Guido, o senhor Malfenti, e Olivi, afirmando que eles são obsoletos.

Os dois sábios "empresários", como já se esperava, mostram-se incapazes para administrar, pois dirigem o escritório sem o mínimo conhecimento e astúcia para tanto. Fazem compras sem nenhum planejamento prévio e sem necessidade, contratam como secretária uma bela e vistosa jovem que não tem a mínima qualificação para o cargo. Assim, a empresa está mais para um ambiente de descontração e lazer do que de trabalho, uma vez que Zeno e 
Guido assemelham-se a duas crianças mimadas, manuseando um brinquedo novo que acabaram de ganhar e estão prestes a destruir.

De acordo com Maria Teresa Nunes Sanches, o

discurso do narrador desenvolve-se de forma a construir uma paródia da atividade empresarial exercida com tanto orgulho pela burguesia. A noção de paródia pode ser exemplificada, ainda, na forma como Guido procede na seleção das correspondências comerciais que deverão ser respondidas prioritariamente ao jogá-las para o alto e apanhando-as no ar (SANCHES, 2003, p124).

A grande imaturidade do senhor Speier com os negócios o leva à falência, descoberta por nosso protagonista que cuidava da parte contábil da empresa. Zeno atribui a bancarrota da casa comercial a um detalhe fundamental, o qual Guido ignorava completamente:

Para fazer prosperar uma casa comercial, era necessário encontrar uma atividade diária para ela, e só se podia chegar a isto trabalhando cada hora em prol da organização. Eu não seria capaz de fazer coisa semelhante, nem me parecia justo submeter-me, por força da bondade, a ser condenado a uma vida de chatura. ${ }^{62}$ (SVEVO, 2006, p.326, grifo nosso)

Contudo, essa "atividade diária" jamais fora buscada. Importante notar que Zeno condena Guido pelo fracasso, jogando toda a responsabilidade da falência nos ombros do cunhado, não assumindo nenhuma participação ou responsabilidade no andamento dos negócios.

Como derradeira tentativa de salvar a empresa, Guido aplica o dinheiro da esposa na Bolsa de Valores. Zeno não apóia a decisão do cunhado, que, no entanto, recebe grande apoio do resto da família. Fracassando mais uma vez, Guido resolve, na tentativa de solucionar o problema, pela segunda vez, simular um suicídio que acaba realmente acontecendo, por um erro de cálculo cometido por ele.

Com a morte do cunhado, Zeno tenta recuperar parte dos bens da família fazendo investimentos na Bolsa de Valores. Com o auxílio de Nilini, que trabalhava como operador na Bolsa de Valores, ele obtém grande êxito. Tão envolvido nessa sua nobre tarefa, ele acaba perdendo o funeral do cunhado, ao acompanhar o cortejo errado. Esse "incidente" é perdoado 
pela família devido ao sucesso obtido na empreitada financeira. Nosso herói volta a ser não o único homem da família, mas o melhor ${ }^{63}$ (SVEVO, 2006, p.380).

Zeno obtém o reconhecimento e o perdão dos Malfenti, inclusive de Ada, mesmo declarando saber que ele não gostava de seu marido. O diálogo entre nosso protagonista e sua "amada" é tenso, vejamos:

Baixou a voz como se quisesse manter em segredo aquilo que me dizia e em sua voz apareceu um pouco mais de calor, um calor que resultava de seu afeto por Guido e (ou assim me pareceu?) também por mim:

— Eu o desculpo por não ter vindo ao enterro. Você não podia fazê-lo e eu perdôo. Ele também o desculparia se estivesse vivo. Que haveria você de fazer naquele enterro? Você, que não gostava dele! Bom como você é, poderia chorar por mim, pelas minhas lágrimas, mas não por ele que você... odiava! Pobre Zeno! Meu pobre irmão!

Era incrível que me pudesse dizer semelhante coisa, alterando desta forma a verdade. Protestei; ela não ouviu. Creio ter gritado, pelo menos senti o esforço na garganta:

- Mas é um erro, uma mentira, uma calúnia. Como você pode acreditar numa coisa destas?

Continuou em voz baixa:

- Mas eu também não soube amá-lo. Nunca o traí, nem mesmo em pensamento, mas sentia que não tinha força para protegê-lo. Eu via a sua vida conjugal e a invejava. Parecia-me melhor do que aquela que me oferecia. Fico-lhe grata por não ter comparecido ao enterro, porque de outra forma não teria compreendido o que só hoje consegui. Agora, ao contrário, vejo e compreendo tudo. Até que eu não amava meu marido: se não, por que haveria de odiar inclusive seu violino, a expressão mais completa de seu grande espírito?

Foi então que apoiei a cabeça sobre o braço e ocultei meu rosto. As acusações que me dirigia eram tão injustas que não se podia discutir, e também a sua irracionalidade era tão mitigada pelo tom afetuoso que a minha reação não podia ser áspera como devia, para se fazer vitoriosa. Além do mais, Augusta já me dera o exemplo de um silêncio respeitoso para não ultrajar nem exasperar tamanha dor. Quando, no entanto, meus olhos descerraram, vi na obscuridade que suas palavras haviam criado um mundo novo, tal como todas as palavras não verdadeiras. Pareceu-me perceber que também eu sempre odiara Guido e que vivera a seu lado, assíduo, à espera de poder golpeá-lo. Em seguida, ela mencionava o violino... Se não soubesse que ela andava às cegas entre a dor e o remorso, teria acreditado que aquele violino fora tirado da caixa como uma parte de Guido para convencer meu espírito da acusação de ódio. ${ }^{64}$ (SVEVO, 2006, p.383-4)

O denso diálogo com a cunhada é importante, pois Zeno assumirá para si mesmo que não gostava realmente do cunhado e, ainda, revelará um lado bastante perverso de Ada que tenta dividir com o cunhado a infelicidade do próprio casamento. Ainda que de maneira ambígua e indireta, segundo Lauretis, o próprio Zeno admite o desejo de morte nas considerações feitas a Guido $^{65}$ (LAURETIS, 1976, p.103, tradução nossa). Ada também conclui que não amara o marido como deveria. Zeno, emocionado com as palavras de sua 
amada, não consegue conter as lágrimas. A conversa, no entanto, é interrompida por um desmaio súbito de Ada e a presença da Senhora Malfenti.

Depois disso, não houve mais espaço para tal assunto. Os cunhados, até a partida de Ada com os filhos para Buenos Aires, junto ao sogro, tratam-se de forma cordial, embora Zeno não consiga conter as lágrimas no momento da partida definitiva da cunhada. Assim, encerra-se um capítulo que coloca à tona as relações intensas e conflitantes de uma típica família burguesa. Certamente, um capítulo não de negativas, mas de grandes emoções e descobertas para nosso protagonista que termina por se firmar como verdadeiro herói desse conto de fadas às avessas, ao devolver a seu clã uma aparente tranqüilidade e harmonia. 


\subsection{QUEM TU ÉS, ZENO COSINI?}

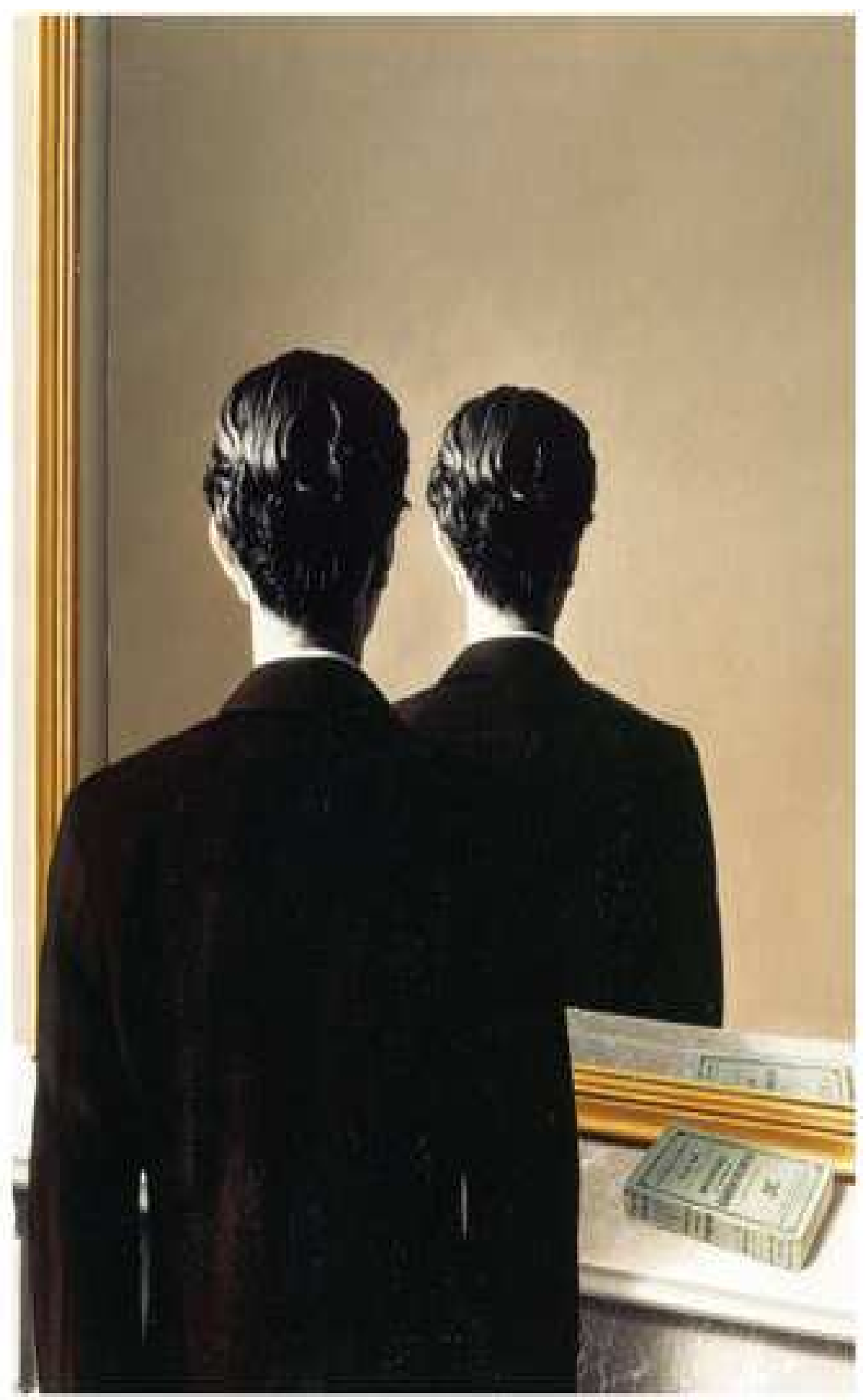

L a Reproduction Interdite. (1937) Rene Magritte 
Quando um homem não encontra a si mesmo, não encontra a nada.

Goethe

Eu não sou eu nem o outro, Sou qualquer coisa de intermédio:

Pilar da ponte de tédio

Que vai de mim para o Outro.

Mario de Sá-Carneiro

Certamente, toda grande obra de arte traz consigo um mistério, algo que, de certa forma, "incomode" o leitor, espectador ou ouvinte, chamando-o a uma reflexão, à decifração de seus enigmas, à decodificação de uma mensagem coerente. Os grandes inventores sempre deixam um ponto de interrogação a ser respondido. Quem nunca "parou" diante da belíssima Monalisa para tentar entender seu enigmático "sorriso"? O que Da Vinci pretendia com essa expressão que, por muitas vezes, foge a nosso entendimento? Tentar decodificar o sorriso de Monalisa não é tão simples, exige esforço e muita reflexão.

Várias interpretações surgiram e ainda surgirão para tentar entendê-lo, todavia, nem todas as significações serão válidas, uma vez que toda obra traz consigo limites para que suas possíveis interpretações mantenham certa coerência. Assim, o sorriso de Monalisa poderá ter várias interpretações desde que a "respeitem", que preservem sua "identidade".

Assim como Monalisa, A consciência de Zeno é uma obra que exige um "olhar" mais atento, mais aguçado acerca de seu protagonista. Com certeza, o romance possui mais de uma leitura, por isso apresentaremos uma interpretação possível, dentre outras já feitas, procurando seguir, no entanto, uma linha que tenha coerência com a narrativa.

Nós, leitores, somos introduzidos no "universo" de Zeno, no fluxo entre o real e fictício de “seu”" tempo ${ }^{66}$ (Lunetta, 1976, p. 106, tradução nossa), um tempo, por assim dizer, tão cindido e entrecortado quanto ele. 
Chegar a uma possível identidade para Zeno não é tão simples, o caminho é íngreme, cheio de pedras e com pouca luz. Contudo, é necessário continuar, "caminhando" com muita cautela, tateando, na penumbra, os objetos dispostos ao longo do trajeto. Só assim conseguiremos sair deste "túnel”, portando uma possível e coerente resposta à pergunta a que nos dispusemos buscar, “Zeno Cosini, quem, de fato, tu és?”.

Antes de darmos formas e contornos à odisséia identitária de Zeno, pensemos nos significados possíveis para o verbete identidade. No dicionário, encontramos diversas acepções, dentre elas, interessam para este trabalho as seguintes: conjunto de caracteres próprios e exclusivos de uma pessoa: nome, idade, estado, profissão, sexo, defeitos físicos, impressões digitais, etc.; e o aspecto coletivo de um conjunto de características pelas quais algo é definitivamente reconhecível, ou conhecido.

Tentaremos, então, apreender o conjunto de características próprias e exclusivas de Zeno, ou seja, quais elementos inerentes à personalidade do protagonista que fazem dele quem ele, de fato, é.

Mario Lunetta diz que o personagem sveviano é caracterizado como alguém que busca a própria dimensão, bem como o posicionamento no interior de uma sociedade burguesa (LUNETTA, 1976, p.51). De fato, Zeno “clama” por sua dimensão, está à procura de sua possível identidade dentro dessa sociedade em que vive.

De acordo com o filósofo Alberto Melucci, a identidade supõe três características: continuidade do sujeito, independentemente das variações no tempo e das adaptações ao ambiente; delimitação desse sujeito em relação aos outros; e capacidade de reconhecer-se e ser reconhecido (MELUCCI, 2004, p.44).

Para Augusto Ponzio, diferentemente, a identidade é uma hibridação (PONZIO, 1997, p.17, tradução nossa). Baseado na teoria bakhtiniana, Ponzio ressalta que somos "seres" dialógicos, nosso discurso sempre repete o discurso do outro, logo o nosso "eu" não pode ser 
totalmente puro, mas um híbrido, resultante de um cruzamento entre "mim" e o outro (PONZIO, 1997, p.17). Conseqüentemente, poderíamos pensar em nossa identidade como uma grande colcha inacabada de diferentes retalhos que está sempre em processo de "reconstrução", uma vez que agregamos, mudamos ou, simplesmente, descosturamos determinado "retalho". Tal processo repete-se "ad infinitum", causando ao ser humano uma fragmentação de sua identidade, "cosida" a partir de diferentes fios, ou melhor, de diferentes discursos e olhares.

Em consonância com esse pensamento, Eric Landowski afirma que a constituição de uma identidade não se encontra apenas na

maneira pela qual, reflexivamente, eu me defino (ou tento me definir) em relação à imagem que outrem me envia de mim mesmo, mas sobretudo na maneira pela qual, transitivamente, objetivo a alteridade do outro atribuindo um conteúdo específico à diferença que me separa dele. (LANDOWSKI, 2002, p.4)

Assim, segundo o crítico, a "construção" de uma identidade alicerça-se na edificação de uma alteridade. Já o teórico russo M. Bakhtin, em seu texto Estética da criação verbal, observa que é graças a uma percepção de minha vida na categoria de outro que meu corpo pode tornar-se esteticamente significante... (BAKHTIN, 1992, p.77). Minha vivência exterior ganha, então, valor estético, a partir do momento em que alguém me faz perceber minha forma exterior como expressão de meu mundo interior.

De fato, é quase impossível não carregarmos um pouco do outro na representação que fazemos de nós mesmos no mundo. Isso justificaria a importância excessiva que o narrador dá ao belo e bem acabado. Zeno demonstra certa repulsa não só pela imagem da esposa fiel e compreensiva que o faz feliz, mas pela sua própria. Sua calvície, seu nariz parecem refletir a inaptidão existencial que ele insiste em afirmar, embora suas ações acabem sempre rendendo bons frutos para si e para a família.

A insatisfação de Zeno aflora no texto "encomendado" pelo psicanalista que o obriga a olhar-se no espelho e a enfrentar sua verdadeira imagem. Este olhar-se altera sua percepção de 
si mesmo e provoca a oscilação do próprio reconhecimento no mundo, além de gerar a dúvida pelo reconhecimento satisfatório de seu "eu" por parte do outro, fato que pode abalar a representação de sua identidade no mundo. Bakhtin comenta ainda que quando eu não posso ter essa percepção

de mim como outro... a minha existência... tende a concentrar-se na minha autoconsciência; ocorre uma volta a mim mesmo...[e] meu próprio reflexo... o que sou para o outro, transforma-se em meu duplo, um duplo que força a entrada na minha consciência, turva-lhe a limpidez, e me desvia de uma relação direta comigo mesmo. (BAKHTIN, 1992, p.77)

Nesse momento, os "pedacinhos" de aprendizado que levamos conosco parecem fragmentar-se para que o "eu" possa distinguir a importância das experiências existenciais na formação de sua vida interior. O relato feito para o Dr. S. força a entrada na consciência (BAKHTIN, 1992, p.77) e traz de volta os anseios, as dúvidas, a consciência do tempo, das realizações e dos fracassos.

O ato da escrita faz com que Zeno, paulatinamente, através de seu olhar astuto, reconheça e incorpore em si algumas qualidades de outrem, deixando-nos um pouco mais reticentes para entendermos sua personalidade que parece estar em constante transformação. Um exemplo disso é sua “obsessão” em relação ao seu sogro, Giovanni Malfenti, a quem diz copiar

O desejo de novidade que havia em meu espírito encontrou perfeita satisfação em Giovanni Malfenti, pessoa completamente diversa de mim e de quantas com quem até então eu buscara a companhia e a amizade. Eu era bastante culto, com passagem por duas universidades e por um período de profunda inércia que reputo bastante instrutiva. Ele, ao contrário, era grande negociante, ativo e tacanho. Contudo, de sua ignorância advinha-lhe força e serenidade, e eu me deslumbrava simplesmente em contemplá-lo, invejando-o.

O Sr. Malfenti contava então cinqüenta anos, dispunha de saúde de ferro, num corpo imenso e alto, pesando mais de cem quilos. As poucas idéias que se lhe agitavam no bestunto emanavam dele com tanta clareza, desentranhadas com tal assiduidade, que se tornavam partes dele, seus membros, seu caráter. Eu era muito pobre de idéias desse gênero e agarrei-me a ele para enriquecer-me. ${ }^{67}$ (SVEVO, 2006, p.68, grifo nosso)

Nessa passagem, como notamos, Zeno declara "espelhar-se" no Senhor Malfenti para poder "enriquecer-se", para poder, enfim, apreender para si uma das qualidades que ele inveja 
no futuro sogro, a habilidade para os negócios, embora este, de acordo com nosso narrador, apresente uma limitada capacidade intelectual, indicada pelos vocábulos grifados por nós. Aqui Zeno servir-se-á de uma característica intrínseca a seu discurso, a ironia, que estudaremos posteriormente.

É importante ressaltar que todo o discurso do ocioso burguês é tecido de modo a evidenciar sua superioridade, ainda que ele pretenda "usurpar-se", absorver algum atributo alheio, não inerente à sua natureza. É como se ele precisasse, o tempo todo, afirmar para si e, para o leitor, o que, na verdade, não é.

Para velar sua identidade, e principalmente para negá-la, Zeno tenta copiar e assemelhar-se às características que contornam o outro, no caso aqui o Senhor Malfenti. Ele não nega essa propensão, esse deslize, deixando isso claro na seguinte fala: Quando admiro uma pessoa, trato imediatamente de parecer-me com ela. Passei a copiar Malfenti ${ }^{68}$ (SVEVO, 2006, p.69).

A propósito da formação da identidade, em consonância com a postura dos teóricos já citados, Wladimir Garcia ressalta que ela é construída pela via do outro (GARCIA, 1994, p.446). Para ele é a partir da afirmação da diferença que ele [artista] fundamenta sua identidade sob a dispersão do eu, sob a devoração do outro (GARCIA, 1994, p.446).

De fato, o burguês tenta diminuir e até anular a identidade do outro, o Senhor Malfenti, no entanto, não consegue absorver, tomar para si a qualidade do outro. Sua incapacidade é maior e ele sempre retorna ao fracasso, à impossibilidade de "ser", servindo-se de suas várias personalidades, que serão oportunamente apresentadas ao leitor.

Segundo estudo de Cristiane Miorin, o discurso que constrói a narrativa de "A consciência de Zeno" estrutura-se de modo a evidenciar um percurso em que a personagem estabelece um processo de metamorfose de personalidade (MIORIN, 2006, p.84). Essa "metamorfose" do protagonista é notada por sua própria mulher. Vejamos a fala de Augusta 
em que isso fica evidente: Augusta percebeu que alguma coisa de novo se passava comigo. E rindo: - Com você a gente nunca se enfada. Cada dia você é um homem diferente. ${ }^{69}$ (SVEVO, 2006, p.264, grifo nosso).

A problemática em torno de uma possível personalidade parece ganhar formas, tomar vulto na obra, que, segundo Luciana Martinelli, é importante por fazer emergir o problema da identidade, cujas raízes nascem a partir da crise ideológica vivida no chamado Novecento (MARTINELLI, 1988, p.104). Tal problema se traduz na grande dificuldade do homem “contemporâneo" de se identificar, de se firmar enquanto um único "eu".

Como afirma Melucci, o eu não está mais solidamente fixado em uma identificação estável: joga, oscila e se multiplica (MELUCCI, 2004, p.15). Essa instabilidade identitária deve-se, em partes, ainda segundo o pensador italiano, ao fato de experimentarmos um tempo cada vez mais fragmentado (MELUCCI, 2004, p.20). O romance, como foi visto anteriormente, não apresenta um tempo linear, os fatos são narrados seguindo o fluxo de consciência do narrador que também se apresentará a nós de maneira despedaçada, múltipla.

Essa multiplicidade é uma característica não só de Zeno, mas de todos nós. A esse respeito é interessante refletirmos sobre a seguinte afirmação de Alberto Melucci. Segundo ele:

Em nosso eu coexistem simultaneamente várias partes, e o aspecto mais fundo da experiência da incerteza nasce justamente da dificuldade de usar apenas uma delas para nos identificar e da obrigatoriedade de fazê-lo para poder agir. Portanto, não é só difícil identificar-nos no tempo e dizer se ainda somos o eu que éramos, mas também, e talvez mais, decidir qual o eu, entre tantos, que podemos ser agora. (MELUCCI, 2004, p. 64)

O protagonista-narrador parece viver esse dilema, uma vez que encontra dificuldades em escolher qual Zeno apresentar a nós leitores. Vale lembrar que a própria tessitura da narrativa, como foi estudada anteriormente, contribui para essa dificuldade em se fixar um dos “eus", uma vez que apreendemos na instância narrativa um Zeno que narra e o outro que é 
narrado. Zeno narrador "reinvoca", analisa e comenta aquilo que Zeno personagem viveu (CLAAR, 1986, p.74).

Essa fragmentação do homem, na verdade, apresenta ligação com o contexto em que ele está inserido. Vivendo em uma sociedade que se transforma, que se "renova" muito rapidamente, o homem terá dificuldades em estabelecer um equilíbrio entre os vetores que constituem a identidade (MELUCCI, 2004, p.52), aumentando, assim, as chances de vivenciar uma "crise de identidade".

Nosso protagonista encontra-se inserido em uma sociedade caracterizada por constantes mudanças e alterações, a qual vive uma crise política e moral, em meio a uma intensa evolução econômica promovida pelo capitalismo e pressionada, ainda, por novas demandas sociais, por meio da organização das classes subalternas que se agrupam e lutam por seus direitos. De acordo com Giorgio Luti, nos anos que precederam a Primeira Guerra Mundial, a sociedade européia passava por uma complexa crise moral, política e econômica, confluindo em uma enorme inquietação social (LUTI, 1961, p.254).

Diante dessa realidade angustiante e "desconcertante", Zeno recorrerá à escritura de suas memórias na tentativa de encontrar a cura da sua maior "doença" que seria, na verdade, a "doença" de toda a humanidade, ou seja, a dificuldade de fixar uma identidade "satisfatória", cuja análise, segundo Micaela Pretolani Claar, reapresentar-se-á por todo o romance (CLAAR, 1986, p74).

Zeno, representante do homem de sua época, já não sabe quem é. Traz consigo muitas perguntas sem respostas. Tenta, aparentemente, responder à celebre pergunta, feita pelo menos uma vez na existência de qualquer ser humano, "Quem sou eu?”. Diante dessa questão, de acordo com Melucci,

procuramos âncoras duradouras e duvidamos da nossa história pessoal. Ainda somos aquilo que éramos? Poderemos ainda ser os mesmos diante dos requisitos do amanhã? Olhamos o nosso passado e o nosso futuro através de lentes distintas, à medida que nos transferimos pelas regiões da experiência. Não temos mais casa e precisamos reconstruí-la continuamente, como os três 
porquinhos da história, ou devemos carregá-la nas costas, como caracóis na era da velocidade. (MELUCCI, 2004, p.61)

Mesmo sem tais “âncoras duradouras”, Zeno tentará responder à pergunta “Quem sou eu?", sairá à procura de sua "identidade”, ou melhor, em busca de se conhecer e reconhecerse. A sua casa será (re-) construída alicerçando-se nas palavras, na escritura de suas “memórias", importante para que ele consiga se "enxergar" enquanto "persona".

A conselho do psicanalista, com o intuito de curar-se de sua hipotética "doença", ele inicia sua "viagem narrativa". De acordo com o suposto psicanalista, esse processo seria importante para que Zeno pudesse se ver por inteiro. Isso fica nítido na seguinte passagem do texto: - Escreva! Escreva! O que acontecerá, então, é que você vai se ver por inteiro ${ }^{70}$ (SVEVO, 2006, p.15).

O começo da redação é difícil, Zeno não sabe começar e invoca a assistência de todos os cigarros, todos iguais àquele que tenho na mão ${ }^{71}$ (SVEVO, 2006, p.15). O cigarro, musa inspiradora de nosso narrador, o acompanhará por todo seu discurso.

Nosso protagonista, de fato, alcançará expressão máxima no incontrolável vício pelo fumo, determinante como símbolo do caráter multifacetado que o caracteriza.

Zeno começa a fumar bem cedo, na infância ainda, conforme podemos apreender através de seu discurso. Barilli defende que a infância constitui o lugar privilegiado onde se decidem os destinos e as características da nossa personalidade ${ }^{72}$ (BARILLI, 1977, p.105, tradução nossa). Assim, podemos dizer que Zeno começa a dar contornos à sua personalidade através do seu vício. A obsessão pelo fumo, na verdade, seria uma espécie de "refletor" de sua identidade também obsessiva, doentia. Vejamos o trecho que denota como sua obsessão pelo cigarro já começa na infância:

Hoje, descubro de repente algo de que não mais me recordava. Os primeiros cigarros que fumei já não se encontram à venda. Pelos anos 70, havia deles na Áustria, vendidos em caixinhas de papelão, estampadas com o brasão da águia bicéfala. Aí está: em volta de uma dessas caixas agrupam-se de repente várias pessoas, mostrando um ou outro traço fisionômico, suficientes 
para sugerir-lhes o nome, mas não tanto para deixar-me comovido pelo inesperado do encontro. Procuro buscar mais e vou para a poltrona: as pessoas esfumam-se, dando lugar a indivíduos cômicos, que escarnecem de mim. Com desconforto, retorno à mesa. ${ }^{73}$ (SVEVO, 2006, p.15)

Tal passagem confirma que o incontrolável vício pelo cigarro tem início muito cedo na vida de nosso protagonista. Um olhar mais atento à mesma passagem permite apreender a personalidade dupla de Zeno. Isso pode ser notado quando ele descreve a estampa da caixinha dos cigarros que ele consumia. Zeno é tão bicéfalo quanto a águia lembrada, carrega consigo a marca da duplicidade. Merece destaque, ainda, o conjunto de pessoas que se agrupam em torno da caixinha do cigarro. Tais pessoas, segundo nosso narrador, mostram "um ou outro traço fisionômico". Zeno também não se mostra por inteiro, encobre seu verdadeiro eu com um véu finíssimo, misterioso e enigmático, que nos deixa em dúvida acerca da veracidade de suas "memórias" e, conseqüentemente, de sua personalidade.

O próprio Zeno chega a afirmar que possui em seu espírito duas personalidades que sempre brigam entre si, mas que chegam à mesma conclusão a respeito dele. Essa reflexão é desencadeada por ciúmes da esposa, quando nosso protagonista é internado por vontade própria para tentar curar-se de seu vício pelo cigarro. Vejamos:

Fui tomado por uma ira que me punha a cabeça a girar. Devo dizer que, como sempre, em meu espírito lutavam duas personalidades; a mais racional delas me dizia: "Imbecil! Por que acha que sua mulher trai você? Não precisaria interná-lo para ter essa oportunidade." A outra, a que certamente queria fumar, também me chamava de imbecil e gritava: "Ignora você a comodidade que advém da ausência do marido? E com o doutor, a quem você está pagando!" ${ }^{74}$ (SVEVO, 2006, p.34, grifo nosso)

O caráter duplo de Zeno é notado, também, por um "amigo leigo" que conseguiu diminuir drasticamente sua silhueta. Zeno chega a sentir inveja deste por tanta disciplina e determinação. A propósito da duplicidade de personalidade, o amigo "gordo emagrecido" pontua que em Zeno:

com o correr do tempo se haviam formado duas personalidades, uma que comandava e outra que lhe era escrava, a qual, tão logo enfraquecia a vigilância, contrapunha-se à vontade do senhor pelo simples amor à liberdade. Era necessário conceder-lhe liberdade absoluta e ao mesmo 
tempo encarar meu vício como algo de novo que visse pela primeira vez. Era preciso não combatê-lo, mas descurá-lo, tratando-o com total indiferença, voltando-lhe as costas como se faz a alguém que achamos indigno de nossa companhia. Simples, não é mesmo ${ }^{75}$ (SVEVO, 2006, p.25)

Bakhtin, em Estética da criação verbal, observa que quanto mais profunda for a pessoa, isto é, quanto mais se aproximar de seu extremo, menos lhe será aplicável um método generalizante, pois a generalização e a formalização apagam as fronteiras entre o homem genial e a mediocridade (BAKHTIN, 1992, p. 411). Assim, embora nosso protagonista tente seguir o conselho do amigo, sua personalidade complexa o impele à dúvida entre os malefícios do cigarro e o prazer de cada tragada. Vence o vício, pois o desejo, a "obsessão" por fumar é maior. Como ele próprio afirma, ainda que fácil, o fim sempre será o mesmo, ou seja, fumar o último cigarro.

Maria Rita Kehl, em seu texto Masculino/Feminino: o olhar da sedução, observa que renegar é: saber e não querer saber. Saber e ignorar. Perceber e esquecer o percebido (KEHL, 1995, p. 415). Zeno, durante todo o texto, "renega" seu desejo, embora saiba que não abdicará dele. Elencaremos, a seguir, uma série de exemplos sobre a questão do fumo que envolve não somente os interesses do protagonista, mas, essencialmente, o julgamento do mundo externo sobre ele. Veremos que, embora Zeno diga querer se encaixar no "modelo perfeito de homem", sua personalidade "bastante profunda" será mais forte e não permitirá que ele "sucumba a essa tentação".

$\mathrm{Na}$ verdade, a coisa pareceu-me simples. É certo que, tendo conseguido com grande esforço eliminar de meu espírito quaisquer propósitos, cheguei a não fumar por várias horas, mas, estando a boca isenta do gosto do fumo, senti um sabor inocente como o que devem sentir os recém-nascidos e veio-me o desejo de um cigarro; mal o fumei porém, adveio o remorso e de novo retornei à resolução que havia tentado suprimir. Tratava-se de uma via mais longa, mas o fim era sempre o mesmo. ${ }^{76}$ (SVEVO, 2006, p.26)

Mesmo consciente dos males do cigarro, como comentamos acima, ele não tem forças, na verdade, não quer abandoná-lo e entrega-se, assim, a seu desejo, uma espécie de "mal necessário". Vejamos o que os cigarros representam para ele: 
O simples fato de apossar-me deles, já vinha pervadido por uma sensação de estremecer, ao darme conta do mal que me estava reservado. Mas mesmo assim fumava-os até sentir a fronte coberta de suores frios e o estômago embrulhando. Não se pode dizer que na infância eu fosse isento de força de vontade. ${ }^{77}$ (SVEVO, 2006, p.16)

Para satisfazer esse seu obsessivo desejo, ele serve-se de armas como a dissimulação e a mentira, metáforas, segundo Miorin, da marginalização ou inclusão social, que será uma constante nessa obra de Svevo (MIORIN, 2006, p.38). Vejamos o trecho em que ele confessa recorrer, a fim de saciar o seu desejo de fumar, a um "vício" ainda pior, o "roubo":

Uma das figuras, de voz meio rouca, era Giuseppe, adolescente de minha idade, e a outra, meu irmão, um ano mais novo que eu, já falecido há tanto tempo. Parece que Giuseppe ganhava muito dinheiro do pai e nos presenteava com aqueles cigarros. Tenho certeza, porém, de que os oferecia mais a meu irmão do que a mim. Vem daí a necessidade que enfrentei para conseguir outros por conta própria. Sucedeu, portanto, que passei a roubar. No verão, meu pai deixava sobre uma cadeira, na sala de jantar, seu colete, em cujo bolso havia sempre alguns trocados: eu catava as moedas necessárias para adquirir a preciosa caixinha e fumava um cigarro após o outro, os dez que ele continha, para não conservar por muito tempo o fruto comprometedor de meu furto. ${ }^{78}$ (SVEVO, 2006, pp.15-16)

De acordo com Guy Debord, a mentira, a dissimulação, o artificial e a representação são características particulares e intrínsecas à sociedade, fazendo parte, portanto, de seu repertório de "qualidades". Em contrapartida, a verdade deixou de existir quase em toda parte, ou, no melhor caso, ficou reduzida a uma hipótese que nunca poderá ser demonstrada (DEBORD, 1997, p.176). Logo, vivemos o império da mentira, que reina absoluta, sendo totalmente aceita e defendida, sem sofrer a menor contestação. Debord ressalta ainda que o indivíduo deve contradizer-se, servir-se do simulacro se deseja receber dessa sociedade um mínimo de consideração (DEBORD, 1997, p.191).

Esse caráter dissimulado, propenso à mentira, parece ser bem praticado e levado à risca por Zeno e vem mais bem delineado em outra passagem, em que podemos perceber, também, a conivência do pai com seus engodos. Ainda que, implicitamente, Zeno deixe nítido o fato de o pai ter conhecimento e compactuar com seus dois "vícios", o do cigarro e do "furto". Vejamos:

Recordo-me de que meu pai um dia me surpreendeu com o colete dele na mão. Eu, com uma desfaçatez que agora não teria e que ainda hoje me repugna (é possível que tal sentimento de repulsa venha a ter mesmo grande importância em minha cura), disse-lhe que fora assaltado pela 
curiosidade de contar os botões de seu colete. Meu pai riu dessa minha disposição para a matemática ou para a alfaiataria e não percebeu que eu tinha os dedos metidos no bolsinho. Seja dito, em meu louvor que bastou aquele risco, provocado por uma inocência que não havia em mim para impedir-me para sempre de roubar. Ou melhor...roubei outras vezes, mas sem sabê-lo. Meu pai deixava pela casa charutos Virginia fumados a meio, equilibrados à borda das mesas e dos cômodos. Eu imaginava que era a sua maneira de jogá-los fora e pensava também que nossa velha criada Catina dali os poria no lixo. Comecei, a fumá-los às escondidas. ${ }^{79}$ (SVEVO, 2006, p.16)

O vício pelo fumo constituir-se-á em uma "idéia fixa", em uma doentia obsessão cujas conseqüências principais serão a angústia e a incapacidade de Zeno em excluir o cigarro de sua vida. Para escapar a esses sentimentos conflitantes e tortuosos, o "pobre" e frágil burguês termina por recorrer, em toda a narrativa, ao que ele chama de último cigarro. Vejamos:

Fui invadido por enorme inquietude. Pensei: "Já que me faz mal, nunca mais hei de fumar, mas antes disso quero fazê-lo pela última vez". Acendi um cigarro e logo me senti revelado da inquietude, apesar de a febre talvez aumentar e de sentir a cada tragada que as amídalas me ardiam como se tocadas por um tição. Fumei o cigarro até o fim com a determinação de quem cumpre uma promessa. E, sempre experimentando dores horríveis, fumei muitos outros enquanto estive acamado. ${ }^{80}$ (SVEVO, 2006, p.19)

Apesar dos males à saúde, causados pelo vício, Zeno nunca chegará, de fato, ao último cigarro, constante e intrínseco à sua existência atormentada. Mesmo porque, como o "doente imaginário" definido por Augusta, Zeno precisa de algo que lhe corroa a saúde, para poder provar que tem razão. Isso pode ser notado no seguinte trecho:

Aquela enfermidade foi a causa de meu segundo distúrbio: o esforço para libertar-me do primeiro. Meus dias acabaram por ser um rosário de cigarros e de propósitos de não voltar a fumar, e, para ser franco, de tempos em tempos são ainda assim. A ciranda do último cigarro começou aos vinte anos e ainda hoje está a girar. Minhas resoluções são agora menos drásticas $\mathrm{e}$, à medida que envelheço torno-me mais indulgente para com minhas fraquezas. Ao envelhecermos, sorrimos da vida e de todo o seu conteúdo. Posso assim dizer que, desde há algum tempo, tenho fumado muitos cigarros... que não serão os últimos. ${ }^{81}$ (SVEVO, 2006, p.19)

O cigarro pode ser entendido ainda como uma via de mão dupla. De um lado é importante por caracterizá-lo, por lhe dar uma identidade, enquanto indivíduo inserido em determinado grupo social, o de fumantes. Vale lembrar que no mundo burguês do início do século XX, a apreciação de um bom cigarro ou charuto equivalia ao conhecimento de um bom vinho, era uma marca da elite burguesa, reafirmava seu status social. Essa identidade como fumante, segundo Melucci, permite a inclusão do indivíduo em determinado grupo, definindo 
os requisitos, os critérios para que se reconheça e seja reconhecido como membro (MELUCCI, 2004, p.47).

Por outro, essa "doença" pelo cigarro pode ser vista como um subterfúgio para mascarar sua fraqueza e incapacidade perante a vida. O próprio Zeno questiona-se acerca disso. Vejamos:

Agora que estou a analisar-me, assalta-me uma dúvida: não me teria apegado tanto ao cigarro para poder atribuir-lhe a culpa de minha incapacidade? Será que, deixando de fumar, eu conseguiria de fato chegar ao homem forte e ideal que eu supunha? Talvez tenha sido essa mesma dúvida que me escravizou ao vício, já que é bastante cômodo podermos acreditar em nossa grandeza latente. ${ }^{82}$ (SVEVO, 2006, p.20)

Para Alfredo Bosi, o vício do fumo é o motivo condutor de A consciência de Zeno. Tudo é centrado na "cura", ou antes, na veleidade da cura. O fumo seria a síntese da velhice, (d)o cinismo, (d)a doença, e (d)o profundo mal-estar que corrói a existência (BOSI, 1988, P.181). Na esteira do pensamento de Bosi, Brombert afirma que os capítulos seguem uns aos outros, unidos pela imagem do cigarro e pela resolução perpetuamente protelada de parar de fumar (BROMBERT, 2001, p.102). Podemos dizer, assim, que é o vício pelo fumo que propicia o nascimento da obra e, conseqüentemente, de nosso herói. Um herói que só pode existir marginal, não centrado ou "normal" como a esposa Augusta, símbolo de uma postura passiva, mas equilibrada diante da vida, sem almejar grandes mudanças. Zeno, em contrapartida, precisa infringir as regras, é duplamente transgressor, enquanto narrador e personagem. O fumo nesse contexto apresenta-se como um índice de sua transgressão.

Com certeza, o cigarro é uma chave importante para decifrarmos Zeno. O vício parece ser uma característica intrínseca a sua "alma". Zeno Cosini não seria Zeno Cosini se não fosse fumante, se não se entregasse a essa "doença”, se não recorresse sempre ao bom propósito de parar de fumar l'ultima sigaretta. Ele não pode parar de fumar, para não perder esse forte traço identitário. O último cigarro poderia ser comparado à pergunta não menos angustiante “Quem sou eu?”. A obsessão pelo cigarro nada mais é do que a obsessão por (re-) conhecer- 
se. O último cigarro que jamais chegará é uma espécie de círculo vicioso que tem começo, mas não fim, porque se o cigarro o caracteriza, a ausência do vício equivaleria à morte. À mesma proporção do eterno último cigarro ele deve responder continuamente à seguinte pergunta: “Quem sou eu?” (MELUCCI, 2004, p.61), assim, fumar e questionar-se o mantêm vivo e "força a entrada na consciência", realizando o personagem e a obra como sujeito e objeto estético da criação literária.

Lunetta associa essa "doença" à identidade mais profunda de Zeno. Para ele, essa é social e manifesta-se em nível de uma patologia individual que pode ser vista como uma “alienação” (LUNETTA, 1976, pp.127-133). A “doença” seria, segundo o mesmo crítico, o grande tema do romance. Vejamos:

E através da doença, que é o grande tema do romance, Svevo determina poeticamente o mal estar do século. Não se trata de um dado clínico, mas de um dado existencial, e tão profundamente existencial que curar-se significaria morrer, parar de fumar o "último cigarro" significaria renunciar a um dos poucos elementos tangíveis que são as comuns epifanias de uma realidade fragmentada. Por este caminho o romancista esclarece profundamente as razões da própria operação... ${ }^{83}$ (LUNETTA, 1976, p.126, tradução nossa)

Teresa de Lauretis atribui, também, ao vício, uma das principais características do narrador-protagonista, como já pontuamos, o fato de Zeno iniciar a escritura de suas memórias, narrar sua história. O cigarro propicia assim a "(re-) construção" de sua vida e de si mesmo. Vejamos:

Para curar-se do vício do cigarro, a mais sintomática e alusiva das suas características, Zeno tenta impor ordem a sua vida, registrando-a por escrito, e ao confiar à escritura o material recalcado e inconsciente, Zeno obtém o conhecimento e a consciência do próprio eu que se reflete no título extraordinariamente ambíguo de A Consciência de Zeno ${ }^{84}$. (LAURETIS, 1976, pp. 81-82, tradução nossa)

Como bem observou Cristiane Miorin, as memórias são de suma importância para tentarmos entender seu protagonista, pois através destas é possível delinear os contornos de um eu que vacila e se fragmenta (MIORIN, 2006, P.51).

Isso pode ser notado já no "Prefácio" que antecede a narração das memórias, quando o caráter de Zeno, como fora ressaltado anteriormente, é colocado em xeque por seu suposto 
médico, cujo caráter e ética são tão suspeitos quanto o comportamento de nosso narrador. Dúbio e não digno de confiança, uma vez que seu discurso será costurado, amarrado por "verdades e mentiras", o leitor tende a iniciar a leitura "viciado", propenso a duvidar dos fatos que se seguirão.

Como salientado anteriormente, esses acontecimentos são apresentados, com exceção, talvez, do prefácio, através do olhar de Zeno. Portanto, não temos outra escolha a não ser mergulharmos nas profundezas desse tecido narrativo para assim apreendermos, através de pistas e indícios deixados pelo narrador, a consciência dita "doente", perturbada e fragmentada desse rico burguês. Tal narrativa, a propósito da observação de Oscar Tacca, representaria na verdade a "consciência" de seu narrador, no caso Zeno Cosini, que não só vê, mas supõe, deduz e conjectura (TACCA, 1983, p.31).

Pertencendo a uma sociedade alienada e doente, nosso protagonista, atento observador, mostrar-nos-á, o tempo todo, que precisa de sua "doença" para sobreviver nesse contexto social. Sua realidade será ordenada, delineada e pintada a partir de sua "obscura mente". Assim, não temos alternativa a não ser acompanhar e tentar entender o "raciocínio" desse sagaz burguês, para então chegarmos a uma conclusão mais lógica acerca de sua possível identidade, que, como vimos, parece ter origens no vício pelo cigarro.

Espécie de representante de sua suposta "doença", o cigarro é importante por exaltar uma das idiossincrasias mais profundas de nosso protagonista, por constituir, alicerçar um dos pilares de sua identidade, pois como já dissemos, Zeno não existiria se não vivesse intensamente essa sua "moléstia", vista por ele, não como algo negativo, mas como algo inerente à alma humana. Esta consistiria, na verdade, em um importante "elixir" capaz de propiciar ao nosso protagonista a realização de seus caprichos e desejos. Vejamos:

Já de tarde, sem nada melhor que fazer, tomei um banho. Sentia o corpo imundo, queria lavarme. Quando, porém, estava no banho, pensei: "Para limpar-me deveria dissolver-me todo nesta água". Corri a vestir-me, mas tão sem vontade que nem me enxuguei devidamente. O dia desapareceu e fiquei à janela a observar as folhas novas e verdes das árvores do jardim. Senti um arrepio; com certa satisfação pensei que fosse de febre. Não desejei a morte, apenas a doença, 
uma doença que me servisse de pretexto para fazer o que queria ou que me impedisse de fazê-lo. ${ }^{85}$ (SVEVO, 2006, p.204, grifo nosso)

Zeno, como podemos notar nessa passagem, clama pela "doença", necessária ao seu ser. Ele não quer ser são, não quer viver a "saúde" das regras sociais, mas a "doença da marginalidade". Não quer ser mais um na multidão, mas afirmar-se como individualidade. A "doença", que se traduz na incapacidade de se adequar interiormente às regras sociais vigentes, permite que ele goze de seus desejos. A esse propósito, vejamos uma fala de nosso protagonista: Recordou-me que eu havia prometido contar a razão de meu mal-estar. Fingi uma doença, a doença que me deveria propiciar a faculdade de fazer sem culpa tudo quanto me agradasse ${ }^{86}$ (SVEVO, 2006, p.206).

A “doença" é importante, ainda, para o autoconhecimento desse narrador. É ela que propicia que nos contemplemos no espelho, que busquemos saber "algo sobre nós". Assim, é através de sua suposta "doença" que ele irá procurar conhecer-se, procurar uma resposta à sua crise existencial. Vejamos uma passagem que demonstra o valor da doença no processo de autoconhecimento: Contudo, mais tarde descobri que ela [Augusta] sequer tinha consciência do que era de fato a saúde. Os saudáveis não se analisam a si próprios, sequer se contemplam no espelho. Só os doentes sabemos algo sobre nós. ${ }^{87}$ (SVEVO, 2006, p.163)

Assim, é na "doença", desencadeada pelo vício do cigarro, que podemos compreender a possível identidade de Zeno, ou melhor, um dos vários "eus" que coexistem em seu ser. O cigarro seria, na verdade, um importante "tijolinho" na construção da casa de nosso protagonista, que sempre estará em processo de (re-) construção.

A moradia, que irá definir Zeno, será erguida aos poucos, acontecimento por acontecimento, página por página, palavra por palavra, num processo que parece não ter fim. Assim como seu discurso, a "identidade" de Zeno parece ser infinita. Como a Fênix sempre estará se re-construindo, nascendo novamente, brotando vigorosamente. Segundo Matteo Palumbo e conforme advertência do próprio Zeno, a sua história pode ser contada outra vez: 
Quase na última página de $A$ consciência de Zeno o personagem que contou a história da sua doença página por página, que remexeu nos interstícios mais ocultos de sua consciência, que narrou os propósitos, as derrotas, os ressentimentos pelos quais passou, adverte que todo o episódio deveria ser contado uma outra vez do início. De fato, só o presente que ele está vivendo autoriza a olhar o passado e a interpretá-lo segundo uma nova e diferente lógica (...) Sem dúvida, "o mundo de Zeno é um produto do seu interminável burburinho, que prossegue ziguezagueando e não tem lei senão a da procrastinação, não conhece outra direção se não a da escritura interminável (unendliche), na qual o fim pode ser continuamente adiado ou pode ainda ser fixada em um ponto qualquer do seu percurso, uma vez que é apenas contingente e, em todo caso, arbitrária" ${ }^{" 88}$. (PALUMBO, 2007, pp.158-159, tradução nossa)

O doutor, quando receber esta parte de meu manuscrito, certamente mo devolverá. É preciso refazê-lo para maior clareza porque como poderia compreender minha vida quando ainda não lhe conhecia o último período? Talvez eu tivesse vivido todos estes anos apenas a fim de me preparar para isto! ${ }^{89}($ SVEVO, 2006, p.420)

O caráter infinito da escritura parece, de fato, influenciar a(s) possível(is) identidade(s) de Zeno, que sempre estará(ão) se renovando, se re-construindo. A sua identidade vem bem sintetizada por ele próprio na seguinte fala:

A vida mais intensa pode ser sintetizada pelo mais rudimentar dos sons, o da onda do mar, que, a partir do momento em que se forma, muda sem cessar até o instante em que morre! Eu também aspirava a transformar-me e desfazer-me, a exemplo de Napoleão e da onda. ${ }^{90}$ (SVEVO, 2006, p.67)

Impossível rotular Zeno como alguém constante e imutável. Sua possível identidade está, justamente, no seu caráter ambíguo e irônico que nos deixa desconfiados de início, em suas "atrapalhadas" empreitadas que acabam por alcançar sucesso, em sua obsessão pelo cigarro, em sua marginalidade, em sua libido. Nele coexistem, de fato, mais de um "eu".

Não podemos nos esquecer de que Zeno nos conta a sua história, ou seja, é um narrador e como tal não tem uma personalidade, mas uma missão, talvez não mais do que uma função: contar (TACCA, 1983, p.65). Por isso aceitamos as suas confissões mesmo sabendo que possam ser falsas, do mesmo modo como tomamos por verdadeira, a seu modo, a simulação, “fictions", “ficciones" 91 . (LAURETIS, 1976, p.111, tradução nossa).

Logo, preferimos acreditar que sua identidade, construída a cada palavra dita/escrita, não pode ser aprisionada, pois não existe uma fórmula exata que vá apreendê-lo como algo fixo. Sua beleza e sua grandeza residem, justamente, na sua multiplicidade que termina por 
garantir-lhe certa unicidade. Sua essência mais profunda, assim como a visão de vida que ele tem, não é boa nem má; é original! ${ }^{92}$ (SVEVO, 2006, p.322). 


\title{
Notas
}

\begin{abstract}
${ }^{1}$ guarda già, come a un invito indeclinabile, a Zeno Cosini: dall'inferno della "senilità" il ponte verso l'inquieta quiete della "coscienza" è oramai gettato.

2 periodo di instancabile riflessione, di scavo profondo e di tensione verso la maturità umana, culturale e espressiva, al quale si situa naturalmente l'esperienza dell'ultima fase della trilogia romanzesca del triestino.
\end{abstract}

${ }^{3}$ la condizione umana, il rapporto tra io e mondo, le modalità, i perché, i come dell'esistenza, le forme dell'universo della coscienza

${ }^{4}$ entrare nel testo in maniera obliqua, di traverso, per la porta di servizio

${ }^{5} \mathrm{Ne}$ ho cinquantasette anni e sono sicuro che se non cesso di fumare o che la psico-analisi non mi guarisca, la mia ultima occhiata dal mio letto di morte non sarà l'espressione del mio desiderio per la mia infermiera, se questa non sarà la mia moglie e se mia moglie avrà permesso che sia bella!

Fui sincero come in confessione...(p.36)

${ }^{6}$ fu colpita da quella malattia che le tolse ogni belezza.

${ }^{7}$ entro i confini del suo territorio (...) risulta il piú forte, e finisce per essere il vincitore

${ }^{8}$ non è né brutta né bella, ma è originale (p.305)

9 “non analizza se stessa" e tanto meno si racconta; essa può essere raccontata solo dal punto di vista del malato e solo a partire dal rifiuto che il malato pronunzia su di essa. In altri termini, Zeno non è soltanto il narratore della sua malattia, ma anche, e nello stesso tempo, il narratore dell' "atroce salute" degli altri (i cosidetti "sani").

${ }^{10}$ Le pubblico per vendetta e spero gli dispiaccia. Sappia però ch'io sono pronto di dividere con lui i lauti onorarii che ricaverò da questa pubblicazione a patto egli riprenda la cura. Sembrava tanto curioso di se stesso! Se sapesse quante sorprese potrebbero risultargli dal commento delle tante verità e bugie ch'egli ha accumulate!... (pp.23-4)

11 il dottor S., che compare solo nella Prefazione, non ha solo la funzione di presentare l'argomento e le intenzioni del narratore - compito tradizionale delle prefazioni - ma anche e soprattutto quello di rivolgersi direttamente al lettore per informarlo che Zeno nella ricostruzione della propria vita ha mescolato verità e menzogna. Questo improbabile medico si inserisce così nel romanzo come um secondo narratore e con il suo tono per metà risentito e per metà accattivante nei riguardi di Zeno, fornisce al lettore tutte le informazioni necessarie per leggere il racconto di Zeno.

${ }^{12}$ Mi domandò se lavoravo. Tutti in città dicevano ch'io non facevo niente ed io temevo egli avesse da invidiarmi mentre in quell'istante avevo l'assoluto bisogno di essere commiserato. Mentii! Gli raccontai che lavoravo nel mio ufficio, non molto, ma giornalmente almeno per sei ore e che poi gli affari molto imbrogliati ereditati da mio padre e da mia madre, mi davano da fare per altre sei ore. (p.110)

${ }^{13}$ Molto tempo dopo appresi da Augusta che nessuna delle tre fanciulle aveva creduto che le mie storielle fossero vere. Ad Augusta apparvero perciò più preziose perché inventate da me, le sembrava fossero più mie che se il destino me le avesse inflitte. (...) La sola che si fosse indignata delle mie bugie fu la seria Ada. (p. 93)

${ }^{14}$ non esiste senza gli avvenimenti, i quali sono la fittizia realtà della narrativa

${ }^{15}$ Presto m'accorsi che al tavolo del Tergesteo, dove si divertiva a rivelarsi quale era e anche un poco peggiore, Giovanni s'imponeva una riserva: non parlava mai di casa sua o soltanto quando vi era costretto, compostamente e con voce un poco più dolce del solito. Portava un grande rispetto alla sua casa e forse non tutti coloro che sedevano a quel tavolo gli sembravano degni di saperne qualche cosa. Colà appresi soltanto che le sue quattro figliuole avevano tutte i nomi dall'iniziale in a, una cosa praticissima, secondo lui, perché le cose su cui era impressa quell'iniziale, potevano passare dall'una all'altra, senz'aver da subire mutamenti. Si chiamavano (seppi subito a mente quei nomi): Ada, Augusta, Alberta e Anna. A quel tavolo si disse anche che tutt'e quattro erano belle. Quell'iniziale mi colpì molto più di quanto meritasse. Sognai di quelle quattro fanciulle legate tanto bene 
insieme dal loro nome. Pareva fossero da consegnarsi in fascio. L'iniziale diceva anche qualche cosa d'altro. Io mi chiamo Zeno ed avevo perciò il sentimento che stessi per prendere moglie lontano dal mio paese. (pp.80-1)

${ }^{16}$ Nel lungo cammino traverso l'Italia, ad onta della mia nuova salute, non andai immune da molte sofferenze. Eravamo partiti senza lettere di raccomandazione e, spessissimo, a me parve che molti degl'ignoti fra cui ci movevamo, mi fossero nemici. Era una paura ridicola, ma non sapevo vincerla. Potevo essere assaltato, insultato e sopra tutto calunniato, e chi avrebbe potuto proteggermi?

Ci fu anche una vera crisi di questa paura della quale per fortuna nessuno, neppur Augusta, s'accorse. Usavo prendere quasi tutti i giornali che m'erano offerti sulla via. Fermatomi un giorno davanti al banco di un giornalaio, mi venne il dubbio, ch'egli, per odio, avrebbe potuto facilmente farmi arrestare come un ladro avendo io preso da lui un solo giornale e tenendone molti, sotto il braccio, comperati altrove e neppure aperti. Corsi via seguito da Augusta a cui non dissi la ragione della mia fretta. (p.159)

${ }^{17}$ Il dottore presta una fede troppo grande anche a quelle mie benedette confessioni che non vuole restituirmi perché le riveda. Dio mio! Egli non studiò che la medicina e perciò ignora che cosa significhi scrivere in italiano per noi che parliamo e non sappiamo scrivere. Una confessione in iscritto è sempre menzognera. Con ogni nostra parola toscana noi mentiamo! Se egli sapesse come raccontiamo con predilezione tutte le cose per le quali abbiamo pronta la frase e come evitiamo quelle che ci obbligherebbero di ricorrere al vocabolario! E proprio così che scegliamo dalla nostra vita gli epsodi da notarsi. Si capisce come la nostra vita avrebbe tutt'altro aspetto se fosse detta nel nostro dialetto. (p.365)

18 un crogiuolo dove si incrociavano e si contrastavano, o vivevano con sospetto, slavi, tedeschi, italiani e fuoriusciti di ogni parte d'Europa.

${ }^{19}$ Meno violento è il proposito e la mia debolezza trova nel mio vecchio animo maggior indulgenza. Da vecchi si sorride della vita e di ogni suo contenuto. Posso anzi dire, che da qualche tempo io fumo molte sigarette... che non sono le ultime. (p.31)

${ }^{20}$ M'è difficile di raccontare della mia corte ad Ada. Vi fu poi una lunga epoca della mia vita in cui io mi sforzai di dimenticare la stupida avventura che proprio mi faceva vergognare di quella vergogna che fa gridare e protestare. "Non sono io che fui tanto bestia!". E chi allora? Ma la protesta conferisce pure un po' di sollievo ed io vi insistetti. Meno male se avessi agito a quel modo un dieci anni prima, a vent'anni! Ma esser stato punito di tanta bestialità solo perchè avevo deciso di sposarmi, mi pare proprio ingiusto. Io che già ero passato per ogni specie di avventure condotte sempre con uno spirito intraprendente che arriva alla sfacciataggine, ecco ch'ero ridivenuto il ragazzetto timido che tenta di toccar la mano dell'amata magari senza ch'essa se ne avveda, eppoi adora quella parte del proprio corpo ch'ebbe l'onore di simile contatto. Questa ch'è stata la più pura avventura della mia vita, anche oggi che son vecchio io la ricordo quale la più turpe. Era fuori di posto, fuori di tempo quella roba, come se un ragazzo di dieci anni si fosse attaccato al petto della balia. Che schifo! (p.91)

${ }^{21}$ una sorta di sistema di autoregolamento analítico, discorsivo e narrativo che gli permette simultaneamente di confessarsi e di relativizzare la confessione.

${ }^{22}$ Devo dire che in certo rapporto io non somigliavo esattamente al ventenne innamorato il quale tace aspettando che l'amata gli si getti al collo. Non m'aspettavo niente di simile. Io avrei parlato, ma più tardi. Se non procedevo, ciò era dovuto ai dubbii su me stesso. Io m'aspettavo di divenire più nobile più forte, più degno della mia divina fanciulla. Ciò poteva avvenire da un giorno all'altro. Perché non aspettare? (p.92)

${ }^{23}$ le relazioni umane più elementari, cioè i rapporti di parentela

${ }^{24}$ _ Io devo dunque sapere e ricordare che voi nin mi amate? (p.136)

${ }^{25}$ — Sì. Io non amo che Ada e sposerei ora voi... (p.136)

${ }^{26}$ - Voi, Zeno, avete bisogno di una Donna che voglia vivere per voi e vi assista. Io voglio essere quella donna. (p.137)

${ }^{27}$ avventura matrimoniale (p.75) 
${ }^{28}$ La salute spinge all'attività e ad addossarsi un mondo di seccature. Chiusi i musei, cominciarono gli acquisti. Essa, che non vi aveva mai abitato, conosceva la nostra villa meglio di me e sapeva che in una stanza mancava uno specchio, in un'altra un tapetto e che in una terza v'era posto per una statuina. Comperò i mobili di un intero salotto e, da ogni città in cui soggiornammo, fu organizzata almeno una spedizione. A me pareva che sarebbe stato più opportuno e meno fastidioso di fare tutti quegli acquisti a Trieste. Ecco che dovevamo pensare alla spedizione, all'assicurazione e alle operazioni doganali. (p.158)

${ }^{29}$ Ritornato dal viaggio di nozze, ebbi la sorpresa di non aver mai abitata una casa tanto comoda e calda. Augusta v'introdusse tutte le comodità che aveva avute nella propria, ma anche molte altre ch'essa stessa inventò. La stanza da bagno, che a memoria d'uomo era stata sempre in fondo a un corrodoio a mezzo chilometro dalla mia stanza da letto, si accostò alla nostra e fu fornita di un numero maggiore di getti d'acqua. Poi una stanzuccia accanto al tinello fu convertita in stanza da caffè. Imbottita di tapetti e addobbata da grande poltrone in pelle, vi soggiornavamo ogni giorno per un'oretta dopo colazione. Contro mia voglia, vi era tutto il necessario per fumare. Anche il mio piccolo studio, per quanto io lo difendessi, subì delle modificazioni. Io temevo che i mutamenti me lo rendessero odioso e invece subito m'accorsi che solo allora era possibile viverci. Essa dispose la sua illuminazione in modo che potevo leggere seduto al tavolo, sdraiato sulla poltrona o coricato sul sofà. Persino per il violino fu provveduto un leggìo con la sua brava lampadina che illuminava la musica senza ferire gli occhi. Anche colà, e contro mia voglia, fui accompagnato da tutti gli ordigni necessarii per fumare tranquilamente. (p.162)

${ }^{30}$ gli ordigni necessarii (...) fumare tranquilamente.

${ }^{31}$ Della prima fase so che Augusta si diceva perfettamente soddisfatta di me. Quando non l'assaltavo, divenivo di una loquacità straordinaria. La loquacità era un mio bisogno. Me ne procurai l'opportunità figgendomi in capo l'idea che giacché dovevo sposare Augusta, dovessi anche imprenderne l'educazione. L'educavo alla dolcezza, all'affetto e sopra tutto alla fedeltà. Non ricordo esattamente la forma che davo alle mie prediche di cui taluna m'è ricordata da lei che giammai le obliò. M'ascoltava attenta e sommessa. Io, una volta, nella foga dell'insegnamento, proclamai che se essa avesse scoperto un mio tradimento, ne sarebbe conseguito il suo diritto di ripagarmi della stessa moneta. Essa, indignata, protestò che neppure col mio permesso avrebbe saputo tradirmi e che, da un mio tradimento, a leim non sarebbe risultata che la libertà di piangere. (pp.148-9)

${ }^{32}$ Un giorno, subito dopo il nostro viaggio di nozze, mi lasciai innocentemente trattenere dall'andar a casa a colazione e, dopo di aver mangiato qualche cosa in un bar, restai fuori fino alla sera, rientrato a notte fatta, trovai che Augusta non aveva fatto colazione ed era disfatta dalla fame. Non mi fece alcun rimprovero, ma non si lasciò convincere d'aver fatto male. Dolcemente, ma risoluta, dichiarò che se non fosse stata avvisata prima, m'avrebbe atteso per la colazione fino all'ora del pranzo. Non c'era da scherzare! Un'altra volta mi lasciai indurre da un amico a restar fuori di casa fino alle due di notte. Trovai Augusta che m'aspettava e che batteva i denti dal freddo avendo trascurata la stufa. (p.163)

${ }^{33}$ Ecco che delle quattro fanciulle dalla stessa iniziale una ne moriva in quanto mi riguardava. Come avevano fatto a dirla bella? La prima cosa che in lei si osservava era lo strabismo tanto forte che, ripensando a lei dopo di non averla vista per qualche tempo, la personificava tutta. Aveva poi dei capelli non molto abbondanti, biondi, ma di un colore fosco privo di luce e la figura intera non disgraziata, pure un po' grossa per quell'età. Nei pochi istanti in cui restai solo pensai: "Se le altre tre somigliano a questa!..." (p.82)

${ }^{34}$ Mi ricordai che al vedere Augusta ero stato distratto dalla sua bruttezza visto che m'ero atteso di trovare in quella casa le quattro fanciulle dall'iniziale in a tutte bellissime. Apprendevo ora ch'essa m'amava da molto tempo, ma che cosa provava ciò? Non le diedi la soddisfazione di ricredermi. Quando fossi stato morto, essa ne avrebbe preso un altro. Mitigato il pianto, essa s'appoggiò ancora meglio a me e, subito ridendo, mi domandò: — Dove troverei il tuo successore? Non vedi come sono brutta? (p.161)

${ }^{35}$ Quale importanza m'era attribuita in quel suo picolo mondo! Dovevo dire la mia volontà ad ogni proposito, per la scelta dei cibi e delle vesti, delle compagnie e delle letture. Ero costretto ad una grande attività che non mi seccava. Stavo collaborando alla costruzione di una familia patriarcale e diventavo io stesso il patriarca che avevo odiato e che ora m'appariva quale il segnacolo della salute. E tutt'altra cosa essere il patriarca o dover venerare un altro che s'arroghi tale dignità. Io volevo la salute per me a costo d'appioppare ai non patriarchi la malattia, e, specialmente durante il viaggio, assunsi talvolta volentieri l'atteggiamento di statua equestre. (p.157) 
${ }^{36}$ Lo guardavo per sentire meglio quello ch'egli diceva. Era un bellissimo giovine: le labbra naturalmente socchiuse lasciavano vedere una bocca di denti bianchi e perfetti. L'occhio suo era vivace ed espressivo e, quando s'era scoperto il capo, avevo potuto vedere che i suoi capelli bruni e un po' ricciuti, coprivano tutto lo spazio che madre natura aveva loro destinato, mentre molta parte della mia testa era stata invasa dalla fronte. (p.114)

${ }^{37}$ [Guido]... fece due mie caricature. Nella prima ero rappresentato come, col naso in aria, mi poggiavo su un ombrello puntato a terra. Nella seconda l'ombrello s'era spezzato e il manico m'era penetrato nella schiena. Le due caricature raggiungevano lo scopo e facevano ridere col mezzuccio semplice che l'individuo che doveva rappresentarmi - invero affatto somigliante, ma caratterizzato da una grande calvizie - era identico nel primo e nel secondo schizzo e si poteva perciò figurarselo tanto distratto da non aver cambiato di aspetto per il fatto che un ombrello lo aveva trafitto. (p.138)

${ }^{38}$ tutti risero molto e anzi troppo (...) fui colto dal mio dolore lancinante (pp.138-9)

${ }^{39}$ Trovai una difesa in Augusta. Essa volle che sul mio disegno mettessi la data del nostro fidanzamento perché voleva conservare anche lei quello sgorbio. Un'onda calda di sangue inondò le mie vene a tale segno d'affetto che per la prima volta riconobbi tanto importante per me. (pp.139-40)

${ }^{40}$ formica assidua (p.203)

${ }^{41}$ una buona balia sanissima (p.238)

42 era molto meno brutta di quanto avessi creduto, e la sua più grande belezza la scopersi baciandola: il suo rossore! (pp.147-8)

43 - Chissà se l'amo? E um dubbio che m'accompagnò per tutta la vita e oggidì posso pensare che l'amore accompagnato da tanto dubbio sia il vero amore. (p.141)

${ }^{44}$ Nella mia vita ci furono varii periodi in cui credetti di essere avviato alla salute e alla felicità. Mai però tale fede fu tanto forte come nel tempo in cui durò il mio viaggio di nozze eppoi qualche settimana dopo il nostro ritorno a casa. Cominciò con una scoperta che mi stupì: io amavo Augusta com'essa amava me. Dapprima diffidente, godevo intanto di una giornata e m'aspettavo che la seguente fosse tutt'altra cosa. Ma una seguiva e somigliava all'altra, luminosa, tutta gentilezza di Augusta ed anche - ciò ch'era la sorpresa - mia. Ogni mattina ritrovavo in lei lo stesso commosso affetto e in me la stessa riconoscenza che, se non era amore, vi somigliava molto. Chi avrebbe potuto prevederlo quando avevo zoppicato da Ada ad Alberta per arrivare ad Augusta? Scoprivo di essere stato non un bestione cieco diretto da altri, ma un uomo abilissimo. (p.154)

45 in una simulazione di attività (p.167)

${ }^{46}$ Essa subito decise, perché afferrò la mia mano per trattenermi più sicuramente e mi fece entrare. L'emozione m'oscurò la vista e ritengo sia stata provocata non tanto dal dolce contatto di quella mano, ma da quella familiarità che mi parve decidesse del mio e del destino di Augusta. Perciò credo di essere entrato con qualche riluttanza e quando rievoco la storia del mio primo tradimento, ho il sentimento di averlo compiuto perché trascinatovi. (p.182)

${ }^{47}$ Augusta si mise a ridere di cuore e dichiarò ch'io non ero altro che un malato immaginario. (p.168)

${ }^{48}$ Allora sul volto emaciato del Copler passò qualche cosa che somigliava ad un risentimento. Subito, virilmente, si liberò dallo stato d'inferiorità a cui pareva fosse condannato, aggredendomi con grande energia:

- Malato immaginario? Ebbene, io preferisco di essere un malato reale. Primadi tutto un malato immaginario è una mostruosità ridicola eppoi per lui non esistono dei farmachi mentre la farmacia, come si vede in me, ha sempre qualche cosa di efficace per noi malati veri!

La sua parola sembrava quella di un sano ed io — voglio essere sincero - ne soffersi. (pp.168-9)

${ }^{49}$ Causa l'assalto del Copler, io avevo veramente l'aspetto di un malato e di un malato maltrattato. Augusta sentì il bisogno d'intervenire in mio soccorso. Carezzando la mano che avevo abbandonata sul tavolo, essa disse che la mia malattia non disturbava nessuno e ch'ella non era neppur convinta ch'io credessi d'esser ammalato, perché altrimenti non avrei avuto tanta gioia di vivere. Così il Copler ritornò allo stato d'inferiorità cui era 
condannato. Egli era del tutto solo a questo mondo e se poteva lottare con me in fatto di salute, non poteva contrappormi alcun affetto simile a quello che Augusta m'offriva. Sentendo vivo il bisogno di un'infermiera, si rassegnò di confessarmi più tardi quanto egli m'aveva invidiato per questo. (p.169)

${ }^{50}$ Ogni suo suono mi pareva d'amore. (p.175)

${ }^{51}$ Cantò "La mia bandiera". Dal mio soffice sofà io seguivo il suo canto. Avevo un ardente desiderio di poterla ammirare. Come sarebbe stato bello di vederla rivestita di genialità! Ma invece ebbi la sorpresa di sentire che la voce, quando cantava perdeva ogni musicalità. Lo sforzo l'alterava. Carla non sapeva neppure suonare e il suo accompagnamento monco rendeva anche più povera quella povera musica. Ricordai di trovarmi dinanzi ad una scolara e analizzai se il volume di voce fosse bastevole. Abbondante anzi! Nel piccolo ambiente ne avevo l'orecchio ferito. Pensai, per poter continuare ad incoraggiarla, che solo la sua scuola fosse cativa. (p.176)

52 una promessa di affetto e sopra tutto di assistenza. (p.187)

${ }^{53}$ Quel giorno a tavola, però, cominciai veramente a soffrire. Tra me e Augusta stava la mia avventura, come una grande ombra fosca che mi pareva impossibile non fosse vista anche da lei. Mi sentivo piccolo, colpevole e malato, e sentivo il dolore al fianco come un dolore simpatico che riverberasse dalla grande ferita alla mia coscienza. Mentre distrattamente fingevo di mangiare, cercai il sollievo in un proposito ferreo: "Non la rivedrò più — pensai — e se, per riguardo, la dovrò rivedere, sarà per l'ultima volta”. (p.187)

54 figure complementari che insieme costituiscono la donna ideale di Zeno (madre + amante)

55 — Una bella canaglia! Insudiciare così la própria casa! (p.242)

${ }^{56}$ Correndo verso casa ebbi anche il coraggio di prendermela con l'ordine sociale, come se esso fosse stato la colpa dei miei trascorsi. Mi pareva avrebbe dovuto essere tale da permettere di tempo in tempo (non sempre) di fare all'amore, senz'aver a temerne delle conseguenze, anche con le donne che non si amano affatto. (p.206)

${ }^{57}$ Più tardi, quando fui effettivamente l'amante di Carla, riandando col pensiero a quel triste pomeriggio non arrivai a intendere perché prima d'impegnarmi più oltre, non mi fossi arrestato con un virile proposito. Avevo tanto pianto il mio tradimento prima di commetterlo, che si sarebbe dovuto credere facile di evitarlo. Ma del senno di poi si può sempre ridere e anche di quello di prima, perché non serve. Fu marcata in quelle ore angosciose in caratteri grandi nel mio vocabolario alla lettera C (Carla) la data di quel giorno con l'annotazione: "ultimo tradimento". Ma il primo tradimento effettivo, che impegnava a tradimenti ulteriori, seguì soltanto il giorno dopo. (p.199)

${ }^{58} \mathrm{Fu}$ un istante delizioso. Il proposito fatto a due aveva un'efficacia che cancellava qualsiasi colpa. Eravamo innocenti e beati! Il mio benevolo destino m'aveva riservato un istante di felicità perfetta.

Mi sentivo tanto felice che continuai la commedia fino al momento di dividerci. Non ci saremmo visti mai più. Essa rifiutò la busta che portavo sempre nella mia tasca e non volle neppure un ricordo mio. Bisognava cancellare dalla nostra nuova vita ogni traccia dei trascorsi passati. Allora la baciai volentieri paternamente sulla fronte com'essa aveva voluto prima.

Poi, sulle scale, ebbi un'esitazione perché la cosa si faceva un poco troppo seria mentre se avessi saputo ch'essa la dimane sarebbe stata tuttavia a mia disposizione, il pensiero al futuro non mi sarebbe venuto così presto. Essa, dal suo pianerottolo, mi guardava scendere ed io, un po' ridendo, le gridai:

- A domani!

Essa si ritrasse sorpresa e quasi spaventata e si allontanò dicendo:

— Mai più! (pp.240-1)

${ }^{59}$ Per desiderare quell'associazione avevo anche altre ragioni. Io volevo essere utile a Guido! Prima di tutto gli volevo bene e benché egli volesse sembrare forte e sicuro, a me pareva un inerme abbisognante di una protezione che io volontieri volevo accordargli. Poi anche nella mia coscienza e non solo agli occhi di Augusta, mi pareva che più m'attaccavo a Guido e più chiara risultasse la mia assoluta indifferenza per Ada. (p.256)

${ }^{60}$ Io non volevo male a Guido, ma non sarebbe stato certamente l'amico che avrei liberamente prescelto. (p.259)

${ }^{61}$ uffici triestini che puzzano di baccalà o di pellami! (p.258) 
${ }^{62}$ Per far vivere una casa commerciale bisogna crearle un lavoro di ogni giorno e questo si può raggiungere lavorando ogni ora attorno ad una organizzazione. Non ero io che potevo fare una cosa simile, né mi pareva giusto di sottopormi a forza di bontà alla condanna della noia a vita. (p.309)

${ }^{63}$ non l'unico uomo della famiglia, ma il migliore. (p.356)

${ }^{64}$ Poi abbassò la voce come se avesse voluto tener segreto quello che mi diceva e nella sua voce vi fu maggior calore, un calore che risultava dal suo affetto per Guido e (o mi parve?) anche per me:

Ed io ti scuso per non esser venuto al suo funerale. Tu non potevi farlo ed io ti scuso. Anche lui ti scuserebbe se fosse ancora vivo. Che ci avresti fatto tu al suo funerale? Tu che non li amavi! Buono come sei, avresti potuto piangere per me, per le mie lagrime, ma non per lui che tu... odiavi! Povero Zeno! Fratello mio!

Era enorme che mi si potesse dire una cosa simile alterando in tale modo la verità. Io protestai, ma essa non mi sentì. Credo di aver urlato o almeno ne sentii lo sforzo nella strozza:

Ma è un errore, una menzogna, una calunnia. Come fai a credere una cosa simile?

Essa continuò sempre a bassa voce:

- Ma neppure io seppi amarlo. Non lo tradii neppure col pensiero, ma sentivo in modo che non ebbi la forza di proteggerlo. Guardavo ai tuoi rapporti con tua moglie e li invidiavo. Mi parevano migliore di quelli ch'egli mi offriva. Ti sono grata di non essere intervenuto al funerale perché altrimenti non avrei neppur oggi compreso nulla. Così invece vedo e intendo tutto. Anche che io non l'amai: altrimenti come avrei potuto odiare persino il suo violino, l'espressione più completa del suo gande animo?

$\mathrm{Fu}$ allora che io poggiai la mia testa sul braccio e nascosi la mia faccia. Le accuse ch'essa mi rivolgeva erano tanto ingiuste che non si potevano discutere ed anche la loro irragionevolezza era tanto mitigata dal suo tono affettuoso che la mia reazione non poteva essere aspra come avrebbe dovuto per riuscire vittoriosa. D'altronde già Augusta m'aveva dato l'esempio di un silenzio riguardoso per non oltraggiare ed esasperare tanto dolore. Quando però i miei occhi si chiusero, nell'oscurità vidi che le sue parole avevano creato un mondo nuovo come tutte le parole non vere. Mi parve d'intendere anch'io di aver sempre odiato Guido e di essergli stato accanto, assiduo, in attesa di poter colpirlo. Essa poi aveva messo Guido insieme al suo violino. Se non avessi saputo ch'essa brancolava nel suo dolore e nel suo rimorso, avrei potuto credere che quel violino fosse stato sfoderato come parte di Guido per convincere dell'accusa di odio l'animo mio. (pp.358-9)

${ }^{65}$ il desiderio di morte nei riguardi di Guido

${ }^{66}$ nell"”universo" di Zeno, nel flusso tra reale e fittizio del "suo" tempo

${ }^{67}$ Il desiderio di novità che c'era nel mio animo veniva soddisfatto da Giovanni Malfenti ch'era tanto differente da me e da tutte le persone di cui io fino ad allora avevo ricercato la compagnia e l'amicizia. Io ero abbastanza còlto essendo passato attraverso due facoltà universitarie eppoi per la mia lunga inerzia, ch'io credo molto istruttiva. Lui, invece, era un grande negoziante, ignorante ed attivo. Ma dalla sua ignoranza gli risultava forza e serenità ed io m'incantavo a guardarlo, invidiandolo.

Il Malfenti aveva allora circa cinquant'anni, una salute ferrea, un corpo enorme alto e grosso del peso di un quintale e più. Le poche idee che gli si movevano nella grossa testa erano svolte da lui con tanta chiarezza, sviscerate con tale assiduità, applicate evolvendole ai tanti nuovi affari di ogni giorno, da divenire sue parti, sue membra, suo carattere. Di tale idee io ero ben povero e m'attaccai a lui per arricchire. (p.75)

${ }^{68}$ Quando io ammiro qualcuno, tento immediatamente di somigliargli. Copiai anche il Malfenti. (p.76)

${ }^{69}$ Augusta s'accorse che c'era qualche cosa di nuovo in me. Ne rise:

- Con te non ci si può mai annoiare. Sei ogni giorno un uomo nuovo. (p.253)

70 - Scriva! Scriva! Vedrà come arriverà a vedersi intero. (p.27)

${ }^{71}$ l'assistenza delle sigarette tutte tanto somiglianti a quella che ho in mano. (p.27)

${ }^{72}$ l'infanzia costituisca il luogo privilegiato ove si decidono i destini e i caratteri della nostra personalità.

${ }^{73}$ Oggi scopro subito qualche cosa che più non ricordavo. Le prime sigarette ch'io fumai non esistono più in commercio. Intorno al'70 se ne avevano in Austria di quelle che venivano vendute in scatoline di cartone munite del marchio dell'aquila bicipite. Ecco: attorno a una di quelle scatole s'aggruppano subito varie persone con qualche loro tratto, sufficiente per suggerirmene il nome, non bastevole però a commovermi per l'impensato 
incontro. Tento di ottenere di più e vado alla poltrona: Le persone sbiadiscono e al loro posto si mettono dei buffoni che mi deridono. Ritorno sconfortato al tavolo. (p.27)

${ }^{74}$ Mi colse un'ira da farmi girare la testa. Devo confessare che, come sempre, nel mio animo lottavano due persone di cui l'una, la più ragionevole, mi diceva: "Imbecille! Perché pensi che tua moglie ti tradisca? Essa non avrebbe il bisogno di rinchiuderti per averne l'opportunità." L'altra ed era certamente quella che voleva fumare, mi dava pur essa dell'imbecille, ma per gridare: "Non ricordi la comodità che proviene dall'assenza del marito? Col dottore che ora é pagato da te!" (p.45)

75 nel corso degli anni erano andate a formarsi due persone di cui una comandava e l'altra non era altro che uno schiavo il quale, non appena la sorveglianza diminuiva, contravveniva alla volontà del padrone per amore alla libertà. Bisognava perciò dargli la libertà assoluta e nello stesso tempo dovevo guardare il mio vizio in faccia come se fosse nuovo e non l'avessi mai visto. Bisognava non combatterlo, ma trascurarlo e dimenticare in certo modo di abbandonarvisi volgendogli le spalle con noncuranza come a compagnia che si riconosce indegna di sé. Semplice, nevvero? (p.37)

${ }^{76}$ Infatti la cosa mi parve semplice. E poi vero ch'essendo riuscito con grande sforzo ad eliminare dal mio animo ogni proposito, riuscii a non fumare per varie ore, ma quando la bocca fu nettata, sentii un sapore innocente quele deve sentirlo il neonato, mi venne il desiderio di una sigaretta e quando la fumai ne ebbi il rimorso da cui rinnovai il proposito che avevo voluto abolire. Era una via più lunga, ma si arrivava alla stessa meta. (p.37)

${ }^{77}$ Già all'atto d'impadronirmene venivo pervaso da un brivido di ribrezzo sapendo quale malessere m'avrebbero procurato. Poi li fumavo finché la mia fronte non si fosse coperta di sudori freddi e il mio stomaco si contorcesse. Non si dirà che nella mia infanzia io mancassi di energia. (p.28)

${ }^{78}$ Una delle figure, dalla voce un po' roca, era Giuseppe, un giovinetto della stessa mia età, e l'altra, mio fratello, di un anno di me più giovine e morto tanti anni or sono. Pare che Giuseppe ricevesse molto denaro dal padre suo e ci regalasse di quelle sigarette. Ma sono certo che ne offriva di più a mio fratello che a me. Donde la necessità in cui mi trovai di procurarmene da me delle altre. Così avvenne che rubai. D'estate mio padre abbandonava su una sedia nel tinello il suo panciotto nel cui taschino si trovavano sempre degli spiccioli: mi procuravo i dieci soldi occorrenti per acquistare la preziosa scatoletta e fumavo una dopo l'altra le dieci sigarette che conteneva, per non conservare a lungo il compromettente frutto del furto. (p.28)

${ }^{79}$ Poi ricordo che un giorno mio padre mi sorprese col suo panciotto in mano. Io, con una sfacciataggine che ora non avrei e che ancora adesso mi disgusta (chissà che tale disgusto non abbia una grande importanza nella mia cura) gli dissi che m'era venuta la curiosità di contarne i bottoni. Mio padre rise delle mie disposizioni alla matematica o alla sartoria e non s'avvide che avevo le dita nel taschino del suo panciotto. A mio onore posso dire che bastò quel riso rivolto alla mia innocenza quand'essa non esisteva più, per impedirmi per sempre di rubare. Cioè... rubai ancora, ma senza saperlo. Mio padre lasciava per la casa dei sigari virginia fumati a mezzo, in bilico su tavoli e armadi. Io credevo fosse il suo modo di gettarli via e credevo anche di sapere che la nostra vecchia fantesca, Catina li butasse vi. Andavo a fumarli di nascosto. (p. 28)

${ }^{80}$ Mi colse un'inquietudine enorme. Pensai: “Giacché mi fa male non fumerò mai più, ma prima voglio farlo per l'ultima volta". Accesi una sigaretta e mi sentii subito liberato dall'inquietudine ad onta che la febbre forse aumentasse e che ad ogni tirata sentissi alle tonsille un bruciore come se fossero state toccate da un tizzone ardente. Finii tutta la sigaretta con l'accuratezza con cui si compie un voto. E, sempre soffrendo orribilmente, ne fumai molte altre durante la malattia. (p.30)

${ }^{81}$ Quella malattia mi procurò il secondo dei miei disturbi: lo sforzo di liberarmi dal primo. Le mie giornate finirono coll'essere piene di sigarette e di propositi di non fumare più e, per dire subito tutto, di tempo in tempo sono ancora tali. La ridda delle ultime sigarette, formatasi a vent'anni, si muove tuttavia. Meno violento è il proposito e la mia debolezza trova nel mio vecchio animo maggior indulgenza. Da vecchi si sorride della vita e di ogni suo contenuto. Posso anzi dire, che da qualche tempo io fumo molte sigarette... che non sono le ultime. (p.31)

${ }^{82}$ Adesso che son qui, ad analizzarmi, sono colto da un dubbio: che io forse abbia amato tanto la sigaretta per poter riversare su di essa la colpa della mia incapacità? Chissà se cessando di fumare io sarei divenuto l'uomo ideale e forte che m'aspettavo? Forse fu tale dubbio che mi legò al mio vizio perché è un modo comodo di vivere quello di credersi grande di una grandezza latente. (pp.31-2) 
${ }^{83} \mathrm{E}$ attraverso la malattia, che è il grande tema del romanzo, Svevo determina poeticamente il malessere del secolo. Non si tratta di un dato clinico ma di un dato esistenziale, e tanto profondamente esistenziale che guarirne significherebbe morire, smettere di fumare "l'ultima sigaretta" significherebbe rinunciare a uno dei pochi elementi tangibili che sono le pedestri epifanie di una realtà frantumata. Per questa strada il romanziere chiarisce fino in fondo le ragioni della propria operazione...

${ }^{84}$ Per curarsi dal vizio del fumo, la più sintomatica e allusiva delle sue idiosincrasie, Zeno tenta di imporre ordine alla sua vita registrandola per iscritto, e nell'affidare alla scrittura il materiale rimosso e inconscio Zeno ottiene quella conoscenza e quella consapevolezza del proprio io che si riflette nel titolo stupendamente ambiguo della Coscienza di Zeno.

${ }^{85}$ A una tarda ora, non sapendo fare di meglio, presi un bagno. Sentivo una bruttura sul mio corpo e volevo lavarmi. Ma quando fui in acqua pensai: "Per nettarmi dovrei essere capace di scioglermi tutto in quest'acqua". Mi vestii poi, così privo di volontà, che neppure m'asciugai accuratamente. Il giorno saprì ed io restai alla finestra a guardare le nuove foglie verdi degli alberi del mio giardino. Fui colto da brividi e con una certa soddisfazione pensai fossero di febbre. Non la morte desiderai ma la malattia, una malattia che mi servisse di pretesto per fare quello che volevo, o che me lo impedisse. (pp.199-200)

${ }^{86}$ Ella mi ricordò che le avevo promesso di dirle la ragione del mio malessere. Io finsi una malattia, quella malattia che doveva darmi la facoltà di fare senza colpa tutto quello che mi piaceva. (p.201)

${ }^{87}$ Poi, invece, seppi ch'essa neppur sapeva come fosse fatta la salute. La salute non analizza se stessa e neppur si guarda nello specchio. Solo noi malati sappiamo qualche cosa di noi stessi.

${ }^{88}$ Quasi nell'ultima pagina della Coscienza di Zeno il personaggio che ha raccontato la storia della sua malattia per pagine e pagine, che ha scavato negli interstizi più nascosti della sua coscienza, che ha narrato i propositi, le sconfitte, i risentimenti da cui è stata attraversata, avverte che l'intera vicenda dovrebbe essere raccontata un'altra volta dall'inizio. Infatti solo il presente che egli sta vivendo autorizza a guardare il passato e a interpretarlo secondo una nuova e diversa logica(...) Davvero "il mondo di Zeno è in prodotto del suo interminabile borbottio, che procede a zig-zag e non ha legge se non quella della propria procrastinazione, non conosce altra direzione se non quella della scrittura che lo registra e procede, da sinistra verso destra, riga dopo riga e pagina dopo pagina: una scrittura infinibile (unendliche), in cui la fine può essere continuamente rimandata o anche fissata in un punto qualsiasi del suo percorso, perché è soltanto contingente e, in ogni caso, arbitraria".

${ }^{89}$ Il dottore, quando avrà ricevuta quest'ultima parte del mio manoscritto, dovrebbe restituirmelo tutto. Lo rifarei con chiarezza vera perché come potevo intendere la mia vita quando non ne conoscevo quest'ultimo periodo? Forse io vissi tanti anni solo per prepararmi ad esso!

${ }^{90}$ La vita più intensa è raccontata in sintesi dal suono più rudimentale, quello dell'onda del mare, che, dacché si forma, muta ad ogni istante finché non muore! M'aspettavo perciò anch'io di divenire e disfarmi come Napoleone e l'onda. (p.74)

${ }^{91}$ Per questo accettiamo le sue confessioni anche sapendo che possono essere false, nello stesso modo in cui prendiamo per vera, a suo modo, la finzioni, " fictions", "ficciones".

${ }^{92}$ non è né brutta né bella, ma è originale (p.305) 


\section{III - ESCREVO, LOGO EXISTO}

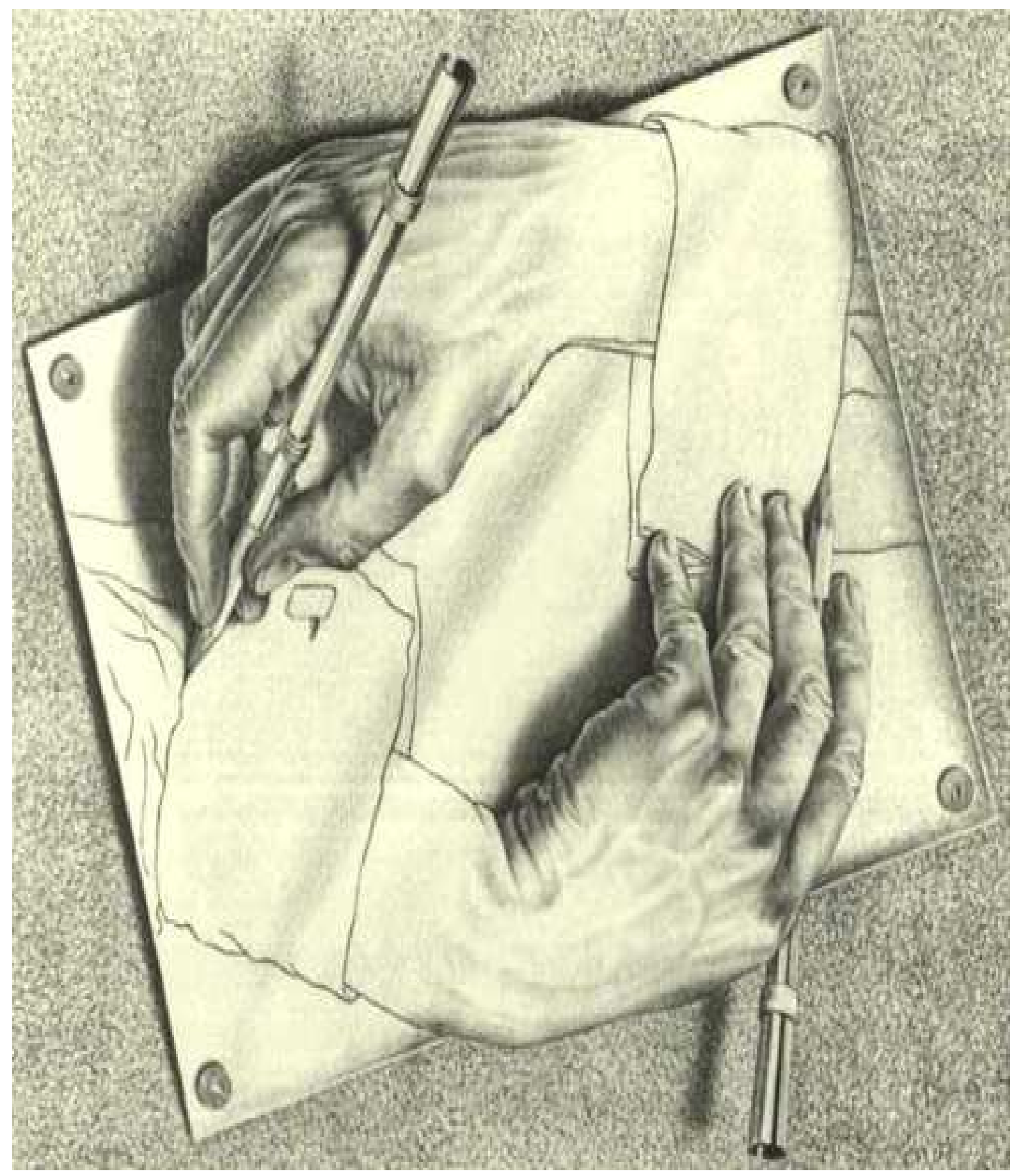

Drawing Hands. (1948) Maurits Cornelis Escher 


\subsection{ESCRITA, MALDIÇÃO QUE SALVA?}

Eu disse uma vez que escrever é uma maldição. Não me lembro por que exatamente eu o disse, e com sinceridade. Hoje repito: é uma maldição, mas uma maldição que salva.

Clarice Lispector

Enquanto eu tiver perguntas e não houver respostas continuarei a escrever.

Clarice Lispector

Com exceção do último capítulo, "Psicanálise", escrito em forma de diário, há no romance A consciência de Zeno a predominância da forma narrativa autobiográfica, ou pseudo-autobiográfica, já que o sujeito que a enuncia está ligado ao mundo ficcional.

O termo pseudo-autobiografia parece ser o mais indicado, uma vez que evidencia que a autobiografia é do narrador, Zeno, e não do escritor, Italo Svevo. Tal pontuação justifica-se pelo fato do grande questionamento, por parte de uma parcela da crítica, quanto à história contada por Zeno tratar-se, na verdade, da própria vida de Svevo. A esse propósito, o escritor tomou uma postura digna de sua grandiosidade como literato. Em uma carta ao amigo Eugenio Montale, Svevo magistralmente joga por terra a suposição de que a autobiografia seria dele e não do personagem ficcional Zeno Cosini:

É verdade que a Coscienza é bem diferente dos romances anteriores. Pense que seja uma autobiografia, não a minha. Muito menos de Senilità. Empreguei três anos para escrevê-lo nos meus retalhos de tempo. E procedi assim: quando estava sozinho procurava convencer-me de que eu era o próprio Zeno. Caminhava como ele, como ele fumava, e jogava no meu passado todas as suas aventuras que pudessem assemelhar-se às minhas, isso porque a reevocação de uma verdadeira aventura é uma reconstrução que facilmente torna-se uma construção totalmente nova, quando se consegue colocá-la em uma atmosfera diversa. E não perde por isso o sabor e o valor da lembrança, e muito menos a sua tristeza. Estou certo que o senhor me entende ${ }^{1}$. (NATALE, 1999, p.135, tradução nossa)

De acordo com Mario Lavagetto, Svevo resolveu esse "problema” com a invenção de um gênero impossível: uma autobiografia de outrem (LAVAGETTO, 2004, pp.LXV-LXVI). 
Ao discorrer sobre a forma narrativa autobiográfica, Jean Pouillon, ressalta que o indivíduo, ao escrever suas memórias, procura entender a razão por ter feito isto ou aquilo, sendo que, nessa empreitada, não é preciso que ele seja sincero, mas lúcido. A reconstituição de um passado só é significativa e possível, ainda de acordo com Pouillon, graças ao que ele chama de imaginação compreensiva (POUILLON, 1974, p.40).

Zeno parece encaixar-se bem nesse contexto, em que a sinceridade parece perder sua autonomia, no qual o mais importante é manter certa coerência com os fatos desencadeados pela imaginação, tornando-os passíveis de convencimento e "aceitação".

Ainda em relação à autobiografia, o crítico Jean Pouillon destaca duas formas: as recordações, nas quais o autor esforça-se por estar "com" aquele que foi um dia, e as memórias, nas quais o autor procura rever-se a fim de se julgar, justificar-se e polemizar, o que supõe que ele separa-se de si mesmo e vê "por detrás" (POUILLON, 1974, p.45, grifo nosso).

No diário, em contrapartida, privilegia-se o hoje. Segundo Pouillon, essa forma de narrativa é uma espécie de registro do tempo presente e das ações que vão se sucedendo, sem que estas afastem em demasia a narração do acontecimento narrado (POUILLON, 1974, p.45).

Partindo dessa definição crítica, podemos dizer que no romance estudado há o predomínio da autobiografia em forma de memórias. O narrador procura rever-se, a fim de buscar sua "cura". Não podemos nos esquecer, porém, de que atrelada a essa forma de narrativa temos o diário, firmado no último capítulo. Neste, ao escrever para si mesmo, sem mais se importar com a presença de um destinatário estabelecido, Zeno teoricamente não precisará mais inventar acontecimentos e episódios ambíguos, poderá ser “sincero". 
O último capítulo, de certa forma, nega, desmascara os anteriores, uma vez que o próprio Zeno reconhece não ter sido muito sincero ao escrever para o Doutor S. Livre dos olhos do médico, ele diz que escreverá sinceramente a história de sua cura. Vejamos:

Havia um ano que não consignava nenhuma palavra aqui, nisto como em tudo o mais seguindo obedientemente as recomendações do médico, que achava indispensável durante o tratamento fossem as minhas reflexões feitas ao seu lado, pois sem a sua vigilância eu estaria reforçando os freios que impediam a minha sinceridade, a minha entrega. ${ }^{2}$ (SVEVO, 2006, p.389)

Empregarei o tempo que me resta livre para escrever. Por isso escreverei sinceramente a história de minha cura. Toda a sinceridade entre o doutor e mim havia desaparecido e hoje respiro aliviado. Nenhum esforço me é mais imposto. Não devo estar constrito a uma fé nem preciso simular que a tenha. Com o propósito de melhor ocultar meu pensamento, acreditava dever demonstrar-lhe um respeito servil, e ele se aproveitava disto para inventar todos os dias novas tramas. ${ }^{3}$ (SVEVO, 2006, p.390, grifo nosso)

Zeno, aqui, segundo Ramos, confessa, declara abertamente o que já havia deixado transparecer nas entrelinhas, na incoerência de certas afirmações (RAMOS, 2001, p.91). Mais do que nunca, temos uma narrativa exclusivamente subjetiva, na qual o eu escreve para si mesmo, em um processo de investigação cujo ponto de saída é ele mesmo.

Teresa de Lauretis defende que no presente romance predomina o caráter de diário íntimo, já que está mais direcionado à investigação da subjetividade do que à realidade exterior, buscando refletir os processos inerentes à "consciência" através do jogo psicológico das relações entre os personagens (LAURETIS, 1976, p.16).

Independente da classificação categórica em uma ou outra forma de narrativa, o importante é que tanto a autobiografia quanto o diário pressupõem um narrador que deve, necessariamente, ser o protagonista. Esse narrador-protagonista contar-nos-á a sua história, registrando-a por intermédio da escrita, importante por caracterizá-lo.

A escrita, inegavelmente, constitui-se em um dos pilares fundamentais que alicerçam as características dos protagonistas svevianos. A escritura, como bem observou o crítico Matteo Palumbo, mais que um meio no qual tais personagens recorrem, é intrínseca à 
natureza destes. Assim como Svevo, seus personagens parecem não conseguir raciocinar sem empunhar a caneta (PALUMBO, 2007, p.165). Ainda, de acordo com Palumbo:

A vocação pela literatura ocupa, de fato, o primeiro lugar entre as qualidades (ou perdições) do "homem inapto", constituindo uma marca da sua alma incompleta, à procura permanente de equilíbrio na ordem da vida: a própria como a dos outros ${ }^{4}$. (PALUMBO, 2007, p.165, tradução nossa)

Como já ressaltamos, no capítulo anterior, na medida em que Zeno escreve sua história “(re-) constrói-se”, legitimando sua existência. Em busca por sua "cura" ele, a conselho do suposto psicanalista, o Doutor S., recorrerá ao papel e à caneta, fazendo uma viagem de volta a seu passado. A lembrança dos primeiros anos é acompanhada por certa dificuldade e hesitação de Zeno:

Rever minha infância? Já lá se vão mais de dez lustros, mas minha vista cansada talvez pudesse ver a luz que dela ainda dimana, não fosse a interposição de obstáculos de toda espécie, verdadeiras montanhas: todos esses anos e algumas horas de minha vida. ${ }^{5}$ (SVEVO, 2006, p.13)

Rever o passado pode não ser fácil, mas será de suma importância para Zeno ir ao encontro de si próprio. Ao iniciar sua "visita" a lugares e acontecimentos outrora vivenciados, através da escrita, ele, como ressaltou o médico, vai se ver por inteiro ${ }^{6}$ (SVEVO, 2006, p.15), contudo, em alguns momentos, Zeno narrador, como já discorremos, parece não se reconhecer na figura de Zeno personagem, narrado por ele. Vejamos:

Na minha sonolência, recordo que o compêndio assegurava, por este sistema, ser possível recordarmos a primeira infância, a dos cueiros. De repente, vejo uma criança de fraldas, mas por que tem de ser eu? Não se parece nada comigo; na verdade, acho que se trata do bebê de minha cunhada, nascido há poucas semanas e que ela mostrava a todos como se fosse um milagre, porque tinha as mãos tão pequenas e os olhos tão grandes. Pobre criança! Ainda bem que se trata de recordar a minha infância! Não saberia encontrar um jeito de te aconselhar, agora que vives a tua, sobre a importância de recordá-la para o bem de tua inteligência e de sua saúde. Quando chegarás a saber que seria bom se pudesses reter na memória a tua vida, até mesmo as partes que te possam repugnar? E, no entanto, inconsciente, vais investigando o teu pequeno organismo à procura do prazer, e as tuas deliciosas descobertas te levarão à dor e à doença, para as quais contribuirão até mesmo aqueles que mais te querem. Que fazer? É impossível tutelar teu berço. No teu seio - pequerrucho! - se vai processando uma combinação misteriosa. Cada minuto que passa, lança-lhe um reagente. Há demasiadas possibilidades de doenças para ti, porque não é possível que sejam puros esses minutos. E além disso - pequerrucho! - és consangüíneo de pessoas que conheço. Os minutos que agora passam até que podiam ser puros, mas tal não foram decerto os séculos que te prepararam. ${ }^{7}$ (SVEVO, 2006, p.14) 
Esse trecho é fundamental para entendermos a maneira pela qual Zeno olha para si mesmo e também para o mundo que o circunda. Inicialmente, notamos a ironia e a descrença do narrador em relação à psicanálise. Note-se que o narrador, leigo no assunto, compra um compêndio não só para entender melhor o tratamento sugerido pelo médico, mas, sobretudo, para manipulá-lo, conforme sua vontade. A psicanálise é colocada, dessa forma, na berlinda, uma vez que seu valor como ciência é questionado, além de mostrar-se teoria enfadonha e causar sonolência. Zeno, assim como Svevo, parece sentir aversão não pelo ímpeto teórico da psicanálise, mas por suas pretensões a curas clínicas (BROMBERT, 2001, p.89).

O tom de deboche prossegue, a terapia o leva de volta à idade "dos cueiros", contudo, a criança, de mãos pequenas e olhos grandes, não se parece nada com ele, na verdade, trata-se do bebê, recém-nascido, de sua cunhada, exibido como uma espécie de troféu.

A ironia ganha um toque de pessimismo. Nosso protagonista faz uma espécie de premonição do futuro da inocente criança que já carrega consigo o germe da doença, pois é consanguiínea de um homem já "doente" desde sua criação. A "doença", vista pelo olhar de Zeno, nasce juntamente com a vida, ambas apresentam-se visceralmente ligadas.

Fazendo parte do "Preâmbulo", tal trecho funciona, de fato, como um proêmio aos capítulos que se seguirão. Nele, podemos notar elementos-chave do discurso de Zeno: ironia, pessimismo, descrença e satirização à psicanálise, bem como a constatação de que toda a humanidade está “doente”.

A confirmação de que a "doença" é intrínseca ao homem será registrada nas últimas páginas de suas memórias. De acordo com Zeno, qualquer esforço de restabelecer a saúde será vão ${ }^{8}$ (SVEVO, 2006, p.421). O homem está contaminado até as "raízes", não existe espaço para a saúde. A única forma que Zeno vislumbra é uma explosão enorme que ninguém 
ouvirá, e a Terra, retornando à sua forma original de nebulosa, errará pelos céus, livre dos parasitos e das enfermidades ${ }^{9}$ (SVEVO, 2006, p.422).

Desse modo, a "confissão" escrita é importante por denotar que não só seu autor é "doente", mas também sua maneira de enxergar a vida como uma incurável moléstia. Nesse processo, escrever, de acordo com Victor Brombert,

assume um valor curativo, uma significação que é estruturada no prefácio do doutor. Mas precisamente na medida em que a dificuldade de viver leva a uma escrita salvadora, o escritorpaciente termina amando a doença que conduz à escrita-remédio. O remédio implica assim que a doença admite um potencial não só negatório, mas também criativo. (BROMBERT, 2001, p.89)

A doença, protagonista no processo da busca pela cura, levará Zeno a escrever suas memórias. Dessa forma, podemos vislumbrar uma inversão de papéis: a doença que, inicialmente, parece ser a vilã na vida de Zeno termina por agir como mais um instrumento para a sua "salvação". O caráter de negação da enfermidade vem diminuído e ofuscado em função de seu potencial criativo, importante para despertar em Zeno a apreensão do ato de criar como transcendental à mentira. Vejamos:

Foi assim que, à força de correr atrás daquelas imagens, eu as alcancei. Sei agora que foram inventadas. Inventar, porém, é uma criação, não uma simples mentira. As minhas eram invenções como as nascidas da febre, que caminham pelo quarto para que possamos vê-las de todos os ângulos, inclusive tocá-las. Tinham a solidez, as cores, a petulância das coisas vivas. À força de desejo, projetei as imagens, que existiam apenas em meu cérebro, no espaço em que as guardava, um espaço do qual sentia o ar, as luzes e até os ângulos contundentes, que não faltaram em nenhum daqueles por onde passei. ${ }^{10}$ (SVEVO, 2006, p.391, grifo nosso)

Inventar e criar, nesse contexto, apresentam significados muito semelhantes. Inventar, do latim inventare, significa "criar na imaginação". Criar, do latim creare, apresenta como significado "dar existência a". Partindo das acepções dos dois verbos e também do discurso de Zeno, reproduzido acima, podemos inferir que nosso protagonista, a partir de sua imaginação, termina por atribuir uma existência "real" a suas criações, fixadas, por assim dizer, em um nível superior à mentira. Assim, Zeno, apropriando-se do pensamento de Svevo, chama 
atenção para que seu leitor acredite na realidade da própria imaginação (PALUMBO, 2007, p.181).

Suas "mentiras", fruto da realidade de sua maneira de apreender o mundo, são destacadas logo no prefácio, escrito por vingança, pelo suposto Doutor S.. Todo o romance, de acordo com Brombert,

move-se em vaivém entre justificativas falazes e as realidades que essas falácias revelam. Uma rede de complacentes mentiras circunda episódios visivelmente triviais: a fuga de Zeno para longe do choro do filho do bebê; seu esquecimento das cerimônias pré-nupciais envolvendo Ada; sua falsa indignação diante do adultério de seu cunhado. Em cada caso ele mostra a si mesmo um aspecto essencial de seu caráter, mas só pode alcançar este insight por causa da rede produtora de mentiras. (BROMBERT, 2001, p.88)

Nesse contexto, em que a suposta mentira parece reinar absoluta, o desejo pela verdade se encontra dialeticamente ligado ao medo da mesma. Nesse jogo em que há um entrelaçamento entre mentiras e verossimilhanças, a primeira agiria como uma ferramenta da veracidade (BROMBERT, 2001, p.88). A lógica cognitiva, na esfera da narrativa, deve aprender e tolerar, no seu interior, a contradição: verdade e sua negação. A presença da negação, a mentira no caso de Zeno, permite aflorar uma outra face da realidade ${ }^{11}$. Ainda que duvidosa e contrastante, a realidade descrita torna-se mais rica e plástica em relação à "verdade" comportamental do homem (CALIFANO, 2000, p.91, tradução nossa).

A única a compreender, desde o início, que as simulações ou petas freqüentes de Zeno são importantes por revelar seu mais profundo eu, é Augusta. Isso se deve, segundo Brombert, exatamente porque as "mentiras" são criadas, inventadas por ele. Suas mentiras, ou antes suas maneiras de mentir, são suas verdades (BROMBERT, 2001, p.88).

Todo elemento, como podemos notar, aparenta ser antagônico e ambivalente: significa ele mesmo e mais alguma coisa". A "saúde", por exemplo, vista por um outro ângulo, tornase doença, que, por sua vez, representa o que a humanidade possui de melhor; a inaptidão pode transformar-se em força e esta, em contrapartida, tornar-se fraqueza. Enfim, tudo é 
fixado em um "terreno" instável, duvidoso e em contínua transformação (PALUMBO, 2007, p.178, tradução nossa).

Para Mimma Califano, verdade e mentira, cada qual no seu próprio contexto, explicam-se e indicam uma espécie de meia verdade; ambas contribuem para a formação de uma verdade contraditória, que na sua ambivalência termina por ser a mais verdadeira, e por enunciar, ainda, os acontecimentos como são (CALIFANO, 2001, p.95).

Diante disso, só resta a nosso protagonista "aceitar" que a linguagem é imperfeita, que é simultaneamente uma doença, uma necessidade, uma mediação inadequada e um acontecimento trágico (...) porquanto as palavras não podem ser levadas de volta (BROMBERT, 2001, p.88). Há uma ruptura entre as épocas da própria existência, suspensas entre o remorso de um bem nunca alcançado e a miragem de uma cura sempre adiada, que serão resolvidos graças ao processo da escritura: um suplemento necessário, que completa a vida e lhe dá "entonação" 13 (PALUMBO, 2007, p.155, tradução nossa).

A escrita, de acordo com Paolo Puppa, é construída, por Svevo, como a única salvação para a vida. Somente aqueles que escrevem conseguem preservar o Tempo, proteger os seres e as coisas. Sem os filtros da escritura nada pode durar ${ }^{14}$. (PUPPA, 1995, p.36, tradução nossa).

A escrita pode não substituir a vida, mas a vida necessita da escrita para ter existência no inquieto "mundo" de Zeno, que fatalmente viverá e inevitavelmente escreverá (PALUMBO, 2001, p.169). A história de seu passado não precisa ser sincera, apenas, conforme o pensamento de Pouillon exposto no início deste texto, lúcida. 


\subsection{NARRATIVA SVEVIANA, SOB OS PILARES DA}

\section{MODERNIDADE}

Não concordo com uma só palavra do que dizeis, mas defenderei até a morte vosso direito de dizê-lo.

Voltaire

Ser moderno é viver uma vida de paradoxo e contradição.

Berman

Não seria cabível analisarmos detalhadamente aqui, a genealogia do romance moderno. O mesmo seria incoerente e contrário ao propósito de nossa pesquisa. Pretendemos, no entanto, levantar algumas hipóteses sobre a "modernidade" e o caráter inovador do romance A consciência de Zeno, de Italo Svevo.

Discorrer sobre o que vem a ser moderno não é tão simples. Trata-se de algo complexo, que exige, de antemão, o estabelecimento de um ponto, um divisor de águas entre, digamos, o tradicional e o moderno, o velho e o novo.

Normalmente, somos propensos a relacionar o dito moderno com algo que se encontra próximo a nós, algo que está na moda ou que existe há pouco tempo. No entanto, Marshall Berman em Tudo que é sólido desmancha no ar, marca o início do século XVI como o ponto de entrada para a Modernidade. A fim de obter certo controle sob algo tão amplo como a história da modernidade, o estudioso a divide em três fases (BERMAN, 2007, p.25).

A primeira fase, de acordo com ele, constaria dos primórdios do século XVI, estendendo-se até o final do século XVIII. Nesse período, as pessoas experimentariam, sem muita consciência, a vida moderna. A segunda fase iniciar-se-ia com a agitação revolucionária de 1790, prolongando-se até o final do século XIX, período de intensas revoluções em todos 
os níveis da vida em sociedade. Na terceira e última fase, iniciada no século XX (BERMAN, 2007, pp.25-6),

o processo de modernização se expande a ponto de abarcar virtualmente o mundo todo, e a cultura mundial do modernismo em desenvolvimento atinge espetaculares triunfos na arte e no pensamento. Por outro lado, à medida que se expande, o público moderno se multiplica em uma multidão de fragmentos, que falam linguagens incomensuravelmente confidenciais; a idéia de modernidade, concebida em inúmeros e fragmentários caminhos, perde muito de sua nitidez, ressonância e profundidade e perde sua capacidade de organizar e dar sentido à vida das pessoas. (BERMAN, 2007, p.26, grifo nosso)

Essa maior abrangência do "processo de modernização", no século XX, vem acompanhada, como podemos notar, da intensificação da multiplicidade e fragmentação do homem, objeto de investigação e "análise" da literatura do mesmo século.

De acordo com Hermann Grosser, uma das principais características da narrativa do Novecento, será a representação do mundo como um espaço enigmático, no qual

o homem contemporâneo não parece mais reconhecer como naturais e humanos os lugares e contextos sociais em que vive, assim como não consegue mais realizar, de modo natural, os gestos e os atos mais comuns da vida cotidiana e "normal" ( o motivo da inaptidão, da incapacidade de viver normalmente) ${ }^{15}$. (GROSSER, 1986, p.174, grifo nosso, tradução nossa)

Esse homem "inapto", incapaz de viver obedecendo às regras consideradas normais, por assim dizer, já não reconhece o ambiente em que vive, e muito menos seu mais profundo eu. Assim teremos o "nascimento" de uma arte que, de acordo com Anatol Rosenfeld, não reconheceria nenhuma relação com o mundo empírico das "aparências", isto é, com o mundo temporal e espacial posto como real e absoluto pelo realismo tradicional e pelo senso comum (ROSENFELD, 1996, p.81).

De acordo com Ramos, os personagens de Svevo enquadram-se nessa fase de negação do compromisso com o mundo empírico ou na terceira fase apontada por Berman (Ramos, 2001, p.230). Conseqüentemente, podemos dizer que o romance A consciência de Zeno é, ou melhor, atua como peça integrante da Modernidade. 
Para Peter Carravetta, a chave para entendermos a Modernidade está na temática do sujeito, da sua gênese, da sua constituição, da sua função (CARRAVETTA, 1995, p.22). Enfim, um sujeito que encontraremos retratado, magistralmente, por nosso escritor triestino.

Svevo colocará em cena o que podemos chamar de escritura do "eu". O autor sairá do tablado, ficará atrás do palco espreitando seus narradores, enquanto nos contarão sua(s) história(s). História(s) aparentemente distante(s) de nossa realidade, a princípio, mas que na verdade assemelham-se às histórias de muitos indivíduos no contexto social urbano e moderno que mergulham dentro de si para tentar descortinar o próprio "eu" mais profundo. Um "eu" costurado por vícios e virtudes, erros e acertos, vitórias e fracassos, em consonância com o verdadeiro comportamento de um cidadão nascido em um século não menos enigmático e múltiplo.

A consciência de Zeno, de acordo com vários estudiosos, formaria, ao lado de seus dois primeiros romances, inicialmente considerados menores, uma tríade em que se tem aprofundada uma temática de fundo autobiográfico que funcionaria, por sua vez, como um instrumento de passagem, uma ponte ao tema principal de sua obra, a análise impiedosa, "tortuosa" do "eu" mais profundo da alma humana.

Escritos em uma época, segundo o crítico Giacomo Debenedetti, cuja corrente literária dominante na Itália era a verista (DEBENEDETTI, 1987, p.518), os primeiros romances de Svevo foram alvo de grande incompreensão.

Essa incompreensão deve-se ao fato de a obra sveviana não se encaixar aos moldes do naturalismo europeu ou do verismo italiano, pois já trazia consigo o germe do novo, rompendo assim com o modelo imposto na época. De acordo com Marzia Vicentini, a crítica reconheceu já na primeira experiência narrativa importante de Svevo,(...) a presença de instâncias narrativas que ultrapassam os limites da concepção naturalista (VICENTINI, 1984, p.29). 
Svevo conseguiu "superar" a ideologia naturalista, de acordo com Micaela Pretolani Claar, através do conhecimento da obra de Schopenhauer, que lhe possibilitou, ainda, descobrir as intrigas do inconsciente, bem como colocá-lo em contato com o pensamento de Nietzsche e as teorias freudianas (CLAAR, 1986, p.105).

É importante ressaltarmos que o romance naturalista já apresentava sinais de "cansaço" e declínio na Europa quando Svevo escreveu seu primeiro romance, Una vita, em 1892 (LAVAGETTO, 2000, p.245). Paulatinamente, temos o surgimento de uma nova narrativa na Itália, cujas raízes, de acordo com Giacomo Debenedetti, aprofundam-se no período pós-Primeira Guerra. De acordo com ele, esta nova narrativa nasce como ruptura (DEBENEDETTI, 1987, p.513), em contraposição ao romance naturalista. O foco principal não está mais na organização dos acontecimentos e sim na apresentação destes (DEBENEDETTI, 1987, p.515). A narrativa deixa de ser explicativa para ser interrogativa, portando consigo inúmeros questionamentos, muitos deles sem respostas, uma vez que

o homem já não sabe (ou não sabe ainda, não reaprendeu a entender) quem é. Não sabe porque a trégua entre ele e a sociedade, entre ele e o mundo, partiu-se. A sociedade com as suas instituições não atende mais às exigências da maioria, por outro lado, as minorias privilegiadas, os grupos de poder, e também aqueles que são beneficiados por estas instituições as percebem como instáveis e ameaçadas, provam a angústia do fim, enquanto aqueles que sofrem pela sobrevivência daquelas instituições, agora insuficientes, vivem a ânsia, a tensão de uma véspera de batalha, associando-se a eles o mal-estar, o sofrimento de uma ausência dos bens e direitos, dos quais já têm consciência de poder cobiçar. Além disso, o homem não está mais de acordo com o mundo, entendido como essência, tanto é verdade que até a física está alterando todas as suas hipóteses sobre a estrutura da matéria e sobre a evolução dos fenômenos ${ }^{16}$. (DEBENEDETTI, 1987, pp.515-16, tradução nossa)

Essa narrativa procurará retratar o homem burguês de sua época, já cindido, segundo Debenedetti, com a sociedade, com o ambiente habitado (DEBENEDETTI, 1987, p.515). Assim, encontraremos um sujeito que parece viver em contraste, em desarmonia com seu mundo. Um indivíduo que já não reconhece o meio em que vive, surgindo daí seus questionamentos, suas dúvidas, suas incertezas, suas insatisfações consigo e com essa realidade que o circunda. 
Em contrapartida à afirmação de Debenedetti, Giorgio Luti defende que não existirá mais a antítese sociedade-personagem, mas existirá o personagem-sociedade, isto é a verdadeira e completa fusão dos dois elementos ${ }^{17}$ (LUTI, 1961, p.260, tradução nossa). Assim, de acordo com esse pressuposto, podemos dizer que o escritor servir-se-á dessa fusão personagem e sociedade para esboçar sua maneira de ver o mundo e, conseqüentemente, de apreender esse homem enigmático.

Ainda que contrastantes, os pressupostos de Debenedetti e Luti terminam por aceitar a narrativa de Svevo como interrogativa, como espécie de espelho refletor dessa sociedade que iluminará o caráter desse homem "moderno", o qual já não consegue mais afirmar quem de fato ele é. Sua identidade está em suspenso, os muros que a delimitavam foram derrubados. Só lhe resta "reconstruir-se" continuamente. É o que acontece com nosso protagonista, Zeno Cosini, que, como já vimos, clamará, durante toda narrativa, por sua identidade, erigindo-a à medida em que narra suas memórias. Assim, as narrativas, de um modo geral, esboçadas por Svevo, de acordo com Luti, funcionam como instrumentos de investigação, como elementos fundamentais do homem voltado a entender-se, a esclarecer seu próprio significado ${ }^{18}$ (LUTI, 1961, p.268, tradução nossa). É na narrativa que o homem buscará suas respostas, buscará (re) conhecer-se. Nesse sentido, podemos dizer que seus romances são, segundo Barberi Squarotti, um exemplo único de penetração progressiva da escritura nas profundezas do eu (BARBERI SQUAROTTI, 1989, p.506).

Pontuada por interrogações, a narrativa apresentará em seu cerne a multiplicidade, uma vez que contará a história de um sujeito também múltiplo, cheio de dúvidas, perguntas, em busca de respostas para seu vazio existencial. Svevo, desse modo, instaura um texto fragmentado e ambíguo que procura representar, o mais fielmente possível, o homem e a sociedade de sua época. 
De acordo com Teresa de Lauretis, a narrativa do século XX abandona a representação de uma realidade objetiva, adotando a representação de uma realidade subjetiva, interior. Assim, teríamos o que a estudiosa chama de romances do eu, ou seja, um romance cuja temática girará em torno das problemáticas que circundam o eu mais profundo do homem (LAURETIS, 1976, p.156). Uma narrativa que pode ser apreendida, conforme observação de Gorizio Viti, como itinerário interior, como epopéia da consciência, como "fluxo de consciência” ${ }^{19}$ (VITI, 1983, P.163, tradução nossa).

Dessa forma, Svevo é importante por dar à luz um romance renovado, livre do peso da tradição e em condições de contar o universo ainda inexplorado que é a modernidade 20 (PALUMBO, 2007, p.135, tradução nossa). O valor do escritor triestino deve-se, de acordo com Matteo Palumbo, à

fundação de uma literatura capaz de falar das histórias cotidianas dos homens, das suas vidas de paixões comuns e de sentimentos normais, mas nem por isso menos surpreendentes e complexas, atravessadas pelo sentimento de novidade que a consciência das obras de Svevo sugerem $^{21}$. (PALUMBO, 2007, pp.135-6, tradução nossa)

Nosso escritor, mais especificamente com A consciência de Zeno, segundo Debenedetti, experimenta, talvez inventa, uma conduta narrativa, uma poética do romance, que certamente lhe parece muito diferente daquele que ele havia presenciado na composição de Una Vita $e$ Senilità $^{22}$ (DEBENEDETTI, 1987, 521, tradução nossa). Svevo abandona, definitivamente, com Zeno, as formas tradicionais da narrativa, renovando-a e inaugurando na literatura italiana, o que Claar intitulou, o estilo do romance moderno (CLAAR, 1986, p.133).

A história de nosso protagonista não segue uma linha linear, cronológica. O tempo esvaiu-se. A organização dos acontecimentos segue a consciência, os caprichos do senhor Zeno Cosini que, desde o início, sentar-se-á, por vontade própria, no banco dos réus, para nos contar sua(s) história(s), toda(s) entrecortada(s) por "verdades" e "mentiras", acumuladas ao longo de sua vida. 
Através do olhar de Zeno, temos composta uma narrativa "mentirosa", ambígua, irônica, que já nasce sob o signo do duplo, uma vez que Zeno narrador-protagonista buscará, como já foi estudado anteriormente, sua possível identidade em Zeno personagem. Contudo, sabemos que a unicidade de um eu pensante já não existe mais. De acordo com Calvino, a mesma foi substituída por uma multiplicidade de sujeitos, vozes, olhares sobre o mundo (CALVINO, 1990, p.132), visto como "sistema de sistemas", em que cada sistema particular condiciona os demais e é condicionado por eles (CALVINO, 1990, p.121).

Para Lavagetto, a grande invenção de Svevo está, justamente, nessa duplicidade das vozes do narrador. De acordo com ele há

um discurso escondido sob o discurso de quem oficialmente fala, confessa, justifica-se, defendese, acusa, constrói com fragmentos, por vezes desconexos e incompatíveis com a própria autoapologia ou, no mínimo, uma versão aceitável dos fatos ${ }^{23}$. (LAVAGETTO, 2004, p. LXVI, tradução nossa)

Essa multiplicidade que acompanha e, de certa forma, "molesta" a narrativa, bem como seu narrador, segundo Italo Calvino, permite apreender o romance contemporâneo como enciclopédia, como método de conhecimento, e principalmente como rede de conexões entre os fatos, entre as coisas do mundo (CALVINO, 1990, p.121). Mimma Bresciani Califano, em consonância à classificação de Calvino, sustenta que o romance torna-se uma enciclopédia de possíveis imagens do mundo, sem que nenhuma venha a encontrar-se em posição de privilégio $^{24}$ (CALIFANO, 2000, p.86, tradução nossa).

O romance trará consigo a complexidade, o caráter multifacetado do mundo representado por ele. Já não há espaço para um discurso inerte, imutável e estável, uma vez que, de acordo com Calvino, cada vida é uma enciclopédia, uma biblioteca, um inventário de objetos, uma amostragem de estilos, onde tudo pode ser continuamente remexido e reordenado de todas as maneiras possíveis (CALVINO, 1990, p.138). Assim, o que foi dito pode ser contado outra vez. Conseqüentemente, temos uma narrativa movediça, em eterna 
metamorfose que acompanha o caráter também movediço e metamorfoseante de nosso protagonista.

Os pilares de uma suposta verdade foram totalmente derrubados. Já não podemos delinear precisamente a fronteira entre o verdadeiro e o fictício, entre realidade e imaginação, centro e margem. O que parece ser verdade inicialmente vem negado e questionado posteriormente, o "real" termina por se apresentar fruto da imaginação e vice-versa. Os opostos parecem intrínsecos ao tecido narrativo, cuja noção de centralidade dissipou-se.

A noção de centro e margem, segundo Conrado Federici, em seu texto L'eccentricità e l'ex-centricità dei protagonisti sveviani, está ligada às características pós-modernas na obra de Svevo. O crítico afirma que o discurso sveviano ressalta a excentricidade, apresentando-a como estratégia narrativa efetuada intencionalmente para contestar os valores culturais do interior da sociedade ${ }^{25}$ (FEDERICI, 1995, p.54, tradução nossa).

Para Federici, essa excentricidade indicaria o comportamento de um personagem que se afasta do convencional, reconhecendo sua marginalidade. Já a ex-centricidade referir-se-ia diretamente à narrativa pós-moderna, uma vez que a obra de arte deixa de ser mimética, voltando-se para sua própria “confecção” e linguagem (FEDERICI, 1995, p.53).

O crítico sustenta que da antinomia centro/margem surgiriam outras séries de opostos, entre elas, saúde/doença, verdade/mentira, superioridade/inferioridade, luz/ sombra, sendo que o primeiro elemento de cada uma delas seria sempre privilegiado por parte do narrador (FEDERICI, 1995, p.57). No caso do romance A consciência de Zeno, sabemos que, mesmo o narrador aproximando-se do primeiro termo de cada série, o personagem estará intrinsecamente ligado ao segundo termo.

Dessa forma, temos uma narrativa alicerçada entre opostos que se inter-relacionam, estabelecendo uma relação pautada em uma espécie de dependência mútua, em que um não existe sem o outro. Tal relação pode ser aplicada também ao eu-narrador e ao eu-personagem; 
Zeno narrador precisa de Zeno personagem para "existir", para buscar sua possível personalidade.

A originalidade, e também modernidade, do romance sveviano parece estar justamente na criação dessa narrativa múltipla, "escorregadia" que, segundo Wladimir Krysinski, deixa sempre uma impressão de ambigüidade que circunda os fatos, os gestos, os pensamentos, as relações, a história e as histórias de Zeno ${ }^{26}$ (KRYSINSKI, 1995, p.161, tradução nossa).

Essa ambigüidade da narrativa sveviana, tão frisada pela crítica, ganha maiores proporções devido à ironia presente no romance. Ela contribui, segundo a leitura crítica de Araguaia S. S. Roque, para ampliar os sentidos expressos no discurso, sempre apontando para uma plurivalência, principalmente por sua característica de atribuir mais sentidos à narrativa, por vezes até mesmo opostos aos manifestados (ROQUE, 2005, p.65).

A seguir, faremos um breve estudo sobre a ironia no romance, visto que constitui mais um elemento característico da narrativa, bem como um instrumento da "não revelação" da personalidade de Zeno. 


\subsection{SÓ SEI QUE NADA SEI : A RE-VELAÇÃO DO DISCURSO IRÔNICO}

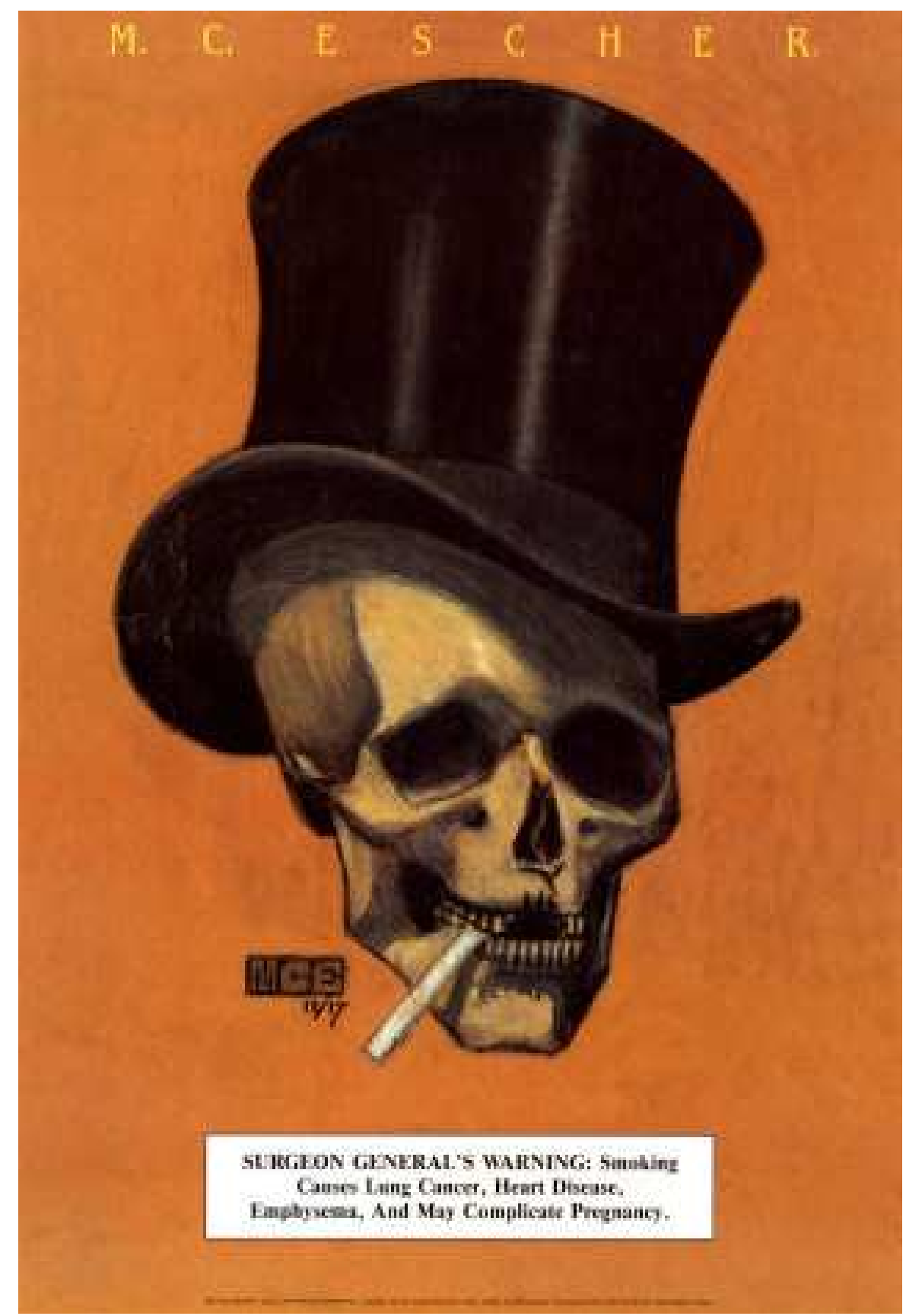

Skull with Cigarette. Maurits Cornelis Escher 
A ironia é minha arma preferida, tudo o que faço precisa ter diversos significados...adoro a ambigüidade...sou dura, ambiciosa e sei exatamente o que quero... À medida em que as pessoas se queixam e me criticam é porque toquei em algum nervo sensível delas!

Madonna

É seu próprio destino que o homem submete ao desafio mediante a derrisão do significante.

Lacan

O romance A consciência de Zeno, do início ao fim, apresenta um discurso totalmente imerso pela insígnia da ironia. Tudo é apresentado de forma a gerar ambigüidade e desconfiança.

Grosso modo, o princípio geral da ironia consiste na inversão, ou seja, em dizer o contrário do que as palavras significam, imprimindo, ainda, ao discurso uma entonação sarcástica, de zombaria, humorística ou outra.

Estratégia de linguagem, a ironia pode ser tomada como procedimento intertextual, interdiscursivo, enfim,

um processo de meta-referencialização, de estruturação do fragmentário e que, como organização de recursos significantes, pode provocar efeitos de sentido como a dessacralização do discurso oficial ou desmascaramento de uma pretensa objetividade em discursos tidos como neutros. (BRAIT, 1996, p.15)

Desse modo, o interdiscurso irônico é importante por propiciar o desnudamento de determinados aspectos culturais, sociais ou mesmo estéticos, encobertos pelos discursos mais sérios e, muitas vezes, bem menos críticos (BRAIT, 1996, p.16). Com o intuito de descortinar valores, denunciar comportamentos, relativizar "verdades", a ironia, além do caráter ambíguo e contrastante, apresenta uma veia interrogativa.

Vale lembrar que, em grego, a primeira acepção da palavra ironia é interrogação, encontrando em Sócrates um de seus "discípulos”. Como se sabe, o filósofo grego procurava converter um pressuposto assertivo em interrogativo, com o objetivo de suscitar no 
interlocutor a compreensão de algo desconhecido ou a ausência de certezas em relação a determinado assunto (BRAIT, 1996, p.21).

Como já ressaltamos no segundo capítulo do presente estudo, toda grande obra de arte porta consigo uma interrogação, cuja finalidade não precisa ser necessariamente uma resposta pontual, mas a reflexão de alguns pressupostos contidos no cerne desta. A ironia socrática, desse modo, constituir-se-á em um instrumento importante na investigação e questionamento de padrões, valores e comportamentos do homem. Homem representado por Zeno Cosini, cujo "espírito burguês", como ressaltou Aurora Bernardini, é desnudado, não propriamente julgado, mas analisado com deleite e artisticamente exorcizado, em suas mistificações (BERNARDINI, 1993, p.3).

Nesse contexto, podemos dizer que o romance, ao colocar como narrador um indivíduo "doente", "mentiroso", não merecedor do menor crédito, insere várias questões a serem pensadas e refletidas. Nesses questionamentos, nos pontos que chamam atenção à reflexão, é que estarão exemplos desse tipo de ironia.

Zeno, nosso Dante já sem a sábia condução de Virgilio, deverá caminhar solitário por seu "inferno", descortinando o seu modo de vida que, na realidade, também é o da sociedade burguesa italiana do início do século XX. Uma sociedade capitalista, consumista, preocupada em manter as aparências, equilibrando-se em um centro fixado por ela própria. A cada capítulo, entramos em contato com diferentes tipos: pais, sogros, cunhados, psicanalista, esposas, maridos, que não ousam desafiar o que já está sacramentado, desfrutando, assim, de plena "saúde" e "bem-estar". Nesse emaranhado, Zeno não se reconhecerá, sentir-se-á doente, excluído, marginal e passará a interrogar-se e interrogar esse mundo que o rodeia.

A "doença", motivo condutor do livro, como foi bem explicitado anteriormente, fará com que nosso protagonista indague-se várias vezes sobre o que de fato vem a ser a 
verdadeira saúde. A esse propósito, vejamos uma fala em que Zeno procura analisar a saúde da esposa,

Estou analisando a sua saúde, mas não consigo fazê-lo, pois acode que, ao analisá-la, converto-a em doença. E ao escrever sobre ela, começo a duvidar sobre se aquela saúde não careceria de cura ou tratamento. Vivendo ao seu lado durante tantos anos, jamais me ocorreu essa dúvida. ${ }^{27}$ (SVEVO, 2006, p.159)

A saúde da esposa Augusta, pessoa sã, equilibrada, centrada e tida como "normal", uma vez que "aceita" as regras impostas pela sociedade, alvo de análise de Zeno, é colocada na berlinda. Nosso protagonista tem dúvidas se de fato trata-se de uma saúde verdadeira, uma vez que parece precisar de cura ou tratamento. A ironia entendida como interrogação reside justamente na reflexão quanto ao caráter saudável da esposa, daí nasce a dúvida e, conseqüentemente, a relativização de um pressuposto tido como verdadeiro e irrefutável: a saúde da mulher. No mesmo excerto, podemos notar a presença da ironia entendida como inversão, introduzida através do jogo das palavras saúde/tratamento/cura, já que uma pessoa saudável não precisa recorrer a nenhum tipo de tratamento, não precisa curar-se. A partir disso, Zeno lança a reflexão e termina por imprimir ambigüidade ao discurso. Nesse contexto, a saúde é relativizada, adquirindo outro sentido.

Tais questionamentos levarão nosso protagonista não só às dúvidas, mas também à reflexão e, conseqüientemente, ao entendimento de si mesmo. A esse propósito, Linda Hutcheon ressalta que o funcionamento subversivo da ironia costuma ser ligado ao conceito de que ela é um modo de autocrítica, autoconhecimento e auto-reflexão (HUTCHEON, 2000, p.53).

Zeno carregará consigo muitas dúvidas. Muitas sem solução ou entendimento. Vejamos um trecho em que ele, ainda criança, questiona seu caráter. Sem saber se é bom ou mau, ele decide recorrer à mãe: 
A dúvida: eu era bom ou mau? A recordação, provocada repentinamente pela dúvida que não era nova: via-me em criança e vestido (estou certo) ainda de calças curtas, erguendo o rosto para perguntar à minha mãe sorridente: "Eu sou bom ou sou mal?" Essa dúvida devia ter sido inspirada ao menino por todos que o achavam bom, e por tantos outros que, de brincadeira, o qualificavam de mau. Não era, portanto, de admirar que a criança se sentisse embaraçada por tal dilema. Oh! Incomparável originalidade da vida! Era extraordinário que a dúvida já infligida por ela à criança, de forma tão pueril, não fosse resolvida pelo adulto depois que transposta metade de sua existência. ${ }^{28}$ (SVEVO, 2006, p.323)

Tal hesitação, intrinsecamente ligada à sua personalidade, permanece nebulosa, sem contornos claros. Zeno não sabe precisar se é bom ou mau. Isso parece não ser importante diante da "originalidade da vida", como ele afirma em seguida. O importante parece estar na busca por si mesmo, em procurar entender seus comportamentos e o mundo do qual faz parte.

Diante de um mundo "caótico" e de uma visão de vida problemática, já sem certezas absolutas, e sem muitas escolhas, Zeno recorrerá à ironia que, segundo Califano, apresentarse-á como a única "arma" de defesa para ele (CALIFANO, 2000, p.91), que fará uso desta por se sentir ameaçado e impotente nas relações sociais (VICENTINI, 1984, p.3).

Ao lançar mão da ironia, concebida aqui como mecanismo de defesa, Zeno além de atacar, também tentará "neutralizar seu alvo". Isso pode ser comprovado por intermédio de um comentário feito por ele a respeito do arranjo final que o rival, Guido, imprime a uma canção de Bach. Vejamos:

- Magnífico! - disse, num tom mais de concessão que de aplauso. - Contudo, não entendo por que no final separou aquelas notas que Bach indicou como legato.

Eu conhecia a Chaconne nota por nota. Foi numa época em que supunha que, para progredir, devia enfrentar empresas semelhantes, e durante muitos meses passei o tempo a analisar compasso por compasso de algumas composições de Bach. (...)

- Bach - acrescentei - é tão discreto na escolha de seus meios que não admite adulterações desse tipo. ${ }^{29}$ (SVEVO, 2006, p.131)

Desprovido de talento com o violino, ameaçado pelos dotes musicais do futuro cunhado e sentindo-se inferior por isso, Zeno busca na ironia um meio de defesa e de agressão descomprometida, indício de seus sentimentos que oscilam entre a admiração, a raiva e o desprezo pelo cunhado e rival que parece sempre poder subjugá-lo. 
A esplêndida performance do cunhado não lhe deixa alternativas a não ser tentar ofuscar o brilho da apresentação, buscado pelo contraste entre algumas palavras. Note que ele, de antemão, aparenta reconhecer o talento de Guido ao usar o adjetivo "magnífico", contudo, logo em seguida, faz um comentário que não está de acordo com tal predicado. O magnífico em si não permitiria "críticas", e não é o que notamos. Na seqüência de sua enunciação, vem o tiro de misericórdia, ao ressaltar que o compositor Bach não admite adulterações desse tipo (SVEVO, 2006, p.131). Se Guido "adulterou" a canção de um grande e importante compositor, ele já não poderia ser magnífico, não é mesmo?

A contradição, que permeia o trecho citado, como bem observou Brait, está no coração do conceito de ironia (BRAIT, 1996, p.61). Em várias passagens das memórias de Zeno, encontraremos elementos cortantes, que terminam por desnudar um pouco mais o caráter de nosso narrador e também por questionar algumas instituições tidas como sagradas, por exemplo, a família. A relação que o senhor Cosini nutre com os pais vem pontuada por sentimentos que parecem não condizer com a realidade de uma família harmoniosa. Vejamos, na seqüência, duas passagens em que ele explicita a morte dos pais:

“15.4.1890, às 4 e 30. Meu pai morreu. U.S.” Para os menos avisados as duas últimas letras não significam United States, mas ultima sigaretta [último cigarro]". É a anotação que encontro num volume de filosofia positiva de Ostwald sobre o qual passei várias horas cheio de esperança e que nunca cheguei a compreender. Ninguém acreditaria mas, malgrado aquela forma, essa anotação registra $o$ acontecimento mais importante de minha vida.

Minha mãe faleceu quando eu não tinha ainda 15 anos. Escrevi versos em sua memória, o que não equivale exatamente a chorar a sua morte e, na minha dor, fui sempre assaltado pelo sentimento de que a partir daquele instante deveria iniciar-se para mim uma vida séria e de trabalho. A própria dor acenava para uma vida mais intensa. Depois, um sentimento religioso sempre vivo atenuou e deliu a grave perda. Minha mãe continuava a viver, embora distante de mim, e poderia compartilhar dos sucessos que eu viesse a alcançar. Uma bela comédia! Recordo exatamente o meu estado de então. A morte de minha mãe e a salutar emoção que me causou fizeram-me sentir que tudo deveria melhorar para mim. ${ }^{30}$ (SVEVO, 2006, pp.39-40)

No primeiro período, a morte do pai vem relatada, desprovida de qualquer sentimento, por parte do filho e delineada com pinceladas irônicas, cujas cores situam-se entre o sarcasmo e a zombaria, na relação criada entre a sigla U.S. e as palavras United States e ultima 
sigaretta. A explicação quanto ao significado da sigla, desnecessário, pois nesse ponto do livro o leitor já pode facilmente prever o verdadeiro sentido desta, imprime o tom irônico, quebrando a seriedade que se esperaria diante da morte de um ente tão próximo. O tom solto, de deboche, é finalizado com a declaração de que a data da morte do pai registra o acontecimento mais importante da vida de Zeno. Dessa forma, temos um discurso que segue na contramão do esperado, fazendo com que o leitor fique mais cético em relação às declarações desse narrador.

No segundo período, Zeno remonta à época da adolescência, para relatar a morte da mãe. O trecho também apresenta ausência de sentimento e é todo entrecortado por contrastes. Nosso narrador, apesar de ter escrito versos em homenagem à mãe, não chora sua morte, e a dor que deveras sente parece profetizar uma vida mais intensa. Novamente, o esperado não acontece, uma vez que diante da dor da morte de um ente tão querido, como a mãe, não se imagina que uma "vida mais intensa" realizar-se-á. Os sentimentos ambíguos parecem compor, como ele próprio ressalta, "uma bela comédia". Seu discurso é terminado de forma ainda mais irônica, ao colocar lado a lado palavras antitéticas como "morte" e "salutar". Nessa ocasião, a morte parece bem distante de suscitar em alguém um sentimento que promova a saúde e muito menos a sensação de que tudo pode ser melhor a partir de então. Diante disso, é necessário que o leitor esteja atento para não cair na teia envolvente do discurso de nosso protagonista.

Dessa forma, na ironia, conforme posição tomada por Beth Brait, a partir dos estudos de Freud, deve-se considerar não só o emissor e o processo instaurador da ironia, mas também o receptor dessa figura retórica. Zeno, desempenhando o papel de ironista, diz o contrário do que quer sugerir, mas (...) insere na mensagem um sinal que, de certa forma, previne o interlocutor de suas intenções (BRAIT, 1996, p.44). Cabe a esse interlocutor, portanto, compreender que a ironia foi utilizada para assim decodificar a verdadeira mensagem contida 
nesse discurso irônico que, mais que qualquer outro, pede do seu enunciatário uma construção interpretativa complexa (BRAIT, 1996, p.109).

Essa inserção de sinais que indiquem a verdadeira intenção do enunciador, levando o enunciatário à desconfiança, é importante por diferenciar o ironista do mentiroso. O primeiro sinaliza de alguma maneira que sua mensagem deve ser entendida não no sentido literal, já o segundo procura apagar de sua fala todo traço de inversão, desqualificando o enunciatário na medida em que tenta fazê-lo aceitar como verdade o que não é (BRAIT, 1996, p.50).

A ironia, como bem ressaltou Linda Hutcheon, retira-nos do império do verdadeiro e do falso para nos colocar no império do ditoso e do desditoso, de modos que ultrapassam $o$ que sugere o uso desses termos na teoria dos atos da fala. A ironia remove a certeza de que as palavras signifiquem apenas o que elas dizem (HUTCHEON, 2000, p.32).

Já germinadas sob o signo do duplo, as palavras, dentro do discurso irônico, serão ainda mais "instáveis", uma vez que farão referência não só ao isto, mas ao aquilo e ao outro. A questão da ambigüidade irônica é explicitada por Brait da seguinte maneira:

A respeito da duplicidade, vários autores se pronunciaram. Já em 1914, num artigo publicado na Révue de Métaphysique et de Morale (pp. 163-201), intitulado "Lê mécanisme de l'ironie dans ses rapports avec la dialectique", René Schaerer não apenas compara a ironia a um jogo de luz e sombra, de claro e escuro, mas também acentua a idéia de que a ambigüidade irônica reside no fato de que o enunciador, ao mesmo tempo que simula, aponta para essa simulação. Um de seus argumentos básicos está no fato de compreender a ironia como uma simulação ou uma dissimulação que é arquitetada deliberadamente para ser desmascarada. Diferentemente da mentira, em que a simulação pretende se passar por verdade, o engano irônico se oferece para que o receptor o adivinhe ou perceba como engano. Nesse sentido, a dissimulação só se torna irônica, segundo Schaerer, no momento em que é denunciada ou percebida como tal. (BRAIT, 1996, p.109)

O enunciador de que fala Brait apresenta, sem sombra de dúvida, o perfil de nosso protagonista, o senhor Zeno Cosini, que simula e aponta para essa simulação, que mente e depois reconhece ter mentido. Contudo, a sinalização de seus engodos, ao invés de permitir seu desmascaramento contribui para ocultá-lo ainda mais, a nosso ver, uma vez que termina por gerar mais dúvidas e desconfianças da veracidade de seu "mentir confessado". 
Como bem frisou Linda Hutcheon,

no discurso irônico, todo o processo comunicativo não é apenas "alterado e distorcido", mas também tornado possível por esses mundos diferentes a que cada um de nós pertence de maneira diferente e que formam a base das experiências, suposições e preconcepções que trazemos ao processamento complexo do discurso, da linguagem em uso. (HUTCHEON, 2000, pp.133-4)

Tão "alterado e distorcido" quanto esse processo comunicativo, o "eu" de nosso protagonista apresentar-se-á múltiplo de significações. Sua identidade abrigará inúmeras possibilidades de compreensão, será exposta de maneira "disforme", de modo a dificultar o reconhecimento de quem ele é de fato. Nesse contexto, a ironia nos é apresentada como mais um recurso na afirmação do caráter duplo de nosso protagonista. Assim como seu discurso irônico, ele abriga em seu interior significados múltiplos que terminam por situá-lo muito além do que nos é apresentado. Diante disso, não temos alternativa a não ser afirmar que só sabemos que nada sabemos acerca de Zeno, que nos "espreita" através de seu discurso envolvente e plurissignificante. 


\section{Notas}

${ }^{1}$ È vero che la Coscienza è tutt'altra cosa dei romanzi precedenti. Ma pensi ch'è un'autobiografia e non la mia. Molto meno di Senilità. Ci misi tre anni a scriverlo nei miei ritagli di tempo. E procedetti così: quand'ero lasciato solo cercavo di convincermi d'essere io stesso Zeno. Camminavo come lui, come lui fumavo, e cacciavo nel mio passato tutte le sue avventure che possono somigliare alle mie solo perché la rievocazione di una propria avventura è una ricostruzione che facilmente diventa una costruzione nuova del tutto quando si riesce a porla in un'atmosfera nuova. E non perde perciò il sapore e il valore del ricordo, e neppure la sua mestizia. Io sono sicuro che Lei m'intende.

${ }^{2}$ Da un anno non avevo scritto una parola, in questo come in tutto il resto obbediente alle prescrizioni del dottore il quale asseriva che durante la cura dovevo raccogliermi solo accanto a lui, perché un raccoglimento da lui non sorvegliato avrebbe rafforzati i freni che impedivano la mia sincerità, il mio abbandono. (p.364)

${ }^{3}$ Impiegherò il tempo che mi resta libero scrivendo. Scriverò intanto sinceramente la storia della mia cura. Ogni sincerità fra me e il dottore era sparita ed ora respiro. Non m'è più imposto alcuno sforzo. Non debbo costringermi ad una fede né ho da simulare di averla. Proprio per celare meglio il vero mio pensiero, credevo di dover dimostrargli un ossequio supino e lui ne approfittava per inventarne ogni giorno di nuove. (pp.364-5)

${ }^{4} \mathrm{La}$ vocazione per la letteratura occupa, infatti, il primo posto tra le qualità ( o le dannazioni) dell' "uomo inetto", costituendo un contrassegno della sua anima incompleta, alla ricerca permanente di equilibri mancanti nell'ordine della vita: la propria come degli altri.

${ }^{5}$ Vedere la mia infanzia? Più di dieci lustri me ne separano e i miei occhi presbiti forse potrebbero arrivarci se la luce che ancora ne riverbera non fosse tagliata da ostacoli d'ogni genere, vere alte montagne: i miei anni e qualche mia ora. (p.25)

${ }^{6}$ arriverà a vedersi intero

${ }^{7} \mathrm{Nel}$ dormiveglia ricordo che il mio testo asserisce che con questo sistema si può arrivar a ricordare la prima infanzia, quello in fasce. Subito vedo un bambino in fasce, ma perché dovrei essere io quello? Non mi somiglia affatto e credo sia invece quello nato poche settimane or sono a mia cognata e che ci fu fatto vedere quale un miracolo perché le mani tanto piccole e gli occhi tanto grandi. Povero bambino! Altro che ricordare la mia infanzia! Io non trovo neppure la via di avvisare te, che vivi ora la tua, dell'importanza di ricordala a vantaggio della tua intelligenza e della tua salute. Quando arriverai a sapere che sarebbe bene tu sapessi mandare a mente la tua vita, anche quella tanta parte di essa che ti ripugnerà? E intanto, inconscio, vai investigando il tuo piccolo organismo alla ricerca del piacere e le tue scoperte deliziose ti avvieranno al dolore e alla malattia cui sarai spinto anche da coloro che non lo vorrebbero. Come fare? E impossibile tutelare la tua culla. Nel tuo seno fantolino! - si va facendo una combinazione misteriosa. Ogni minuto che passa vi getta un reagente. Troppe probabilità di malattia vi sono per te, perché non tutti i tuoi minuti possono essere puri. Eppoi - fantolino! - sei consanguineo di persone ch'io conosco. I minuti che passano ora possono anche essere puri, ma, certo, tali non furono tutti i secoli che ti prepararono. (p.26)

${ }^{8}$ qualunque sforzo di darci la salute è vano. (p.395)

${ }^{9}$ un'esplosione enorme che nessuno udrà e la terra ritornata alla forma di nebulosa errerà nei cieli priva di parassiti e di malattie. (p.396)

${ }^{10}$ È così che a forza di correr dietro a quelle immagini, io le raggiunsi. Ora so di averle inventate. Ma inventare è una creazione, non già una menzogna. Le mie erano delle invenzioni come quelle della febbre, che camminano per la stanza perché le vediate da tutti i lati e che poi anche vi toccano. Avevano la solidità, il colore, la petulanza delle cose vive. A forza di desiderio, io proiettai le immagini, che non c'erano che nel mio cervello, nello spazio in cui guardavo, uno spazio di cui sentivo l'aria, la luce ed anche gli angoli contundenti che non mancarono in alcun spazio per cui io sia passato. (p.366)

\footnotetext{
${ }^{11}$ La presenza della negazione, la bugia nel caso di Zeno, consente di fare affiorare l'altra faccia della realtà.

12 significa se stesso e qualcosa d'altro
} 
${ }^{13}$ un suplemento necessario, che completa la vita e le dà "intonazione"

${ }^{14}$ Senza i filtri della scrittura niente può durare.

15 l'uomo contemporaneo non sembra più riconoscere come naturali e umani i luoghi e i contesti sociali in cui vive, così come non riesce più a compiere in modo naturale i gesti e gli atti più comuni della vita quotidiana $\mathrm{e}$ "normale" (il motivo dell'inettitudine, dell'incapacità di vivere normalmente).

${ }^{16}$ l'uomo non sa più (o non sa ancora, non ha riappreso a capire) chi è. Non lo sa perché è rotta la tregua tra lui e la società, tra lui e il mondo. La società coi suoi istituti non risponde più alle esigenze del maggior numero, d'altronde anche le minoranze privilegiate, i gruppi di potere, anche coloro che beneficiano di quegli istituti li sentono instabili e minacciati, provano l'angoscia di una fine, mentre coloro che soffrono della sopravvivenza di quegli istituti ormai insufficienti vivono l'ansia, la tensione di una vigilia di battaglia, che in loro si associa al malessere, alle sofferenze di una mancanza di beni e di diritti, ai quali sono ormai consci di potere aspirare. L'uomo inoltre non è più d'accordo col mondo, inteso come natura, tanto è vero che anche la fisica sta cambiando tutte le sue ipotesi sulla struttura della materia e sull'andamento dei fenomeni.

17 non esisterà piú l'antitesi società-personaggio, ma esisterà il personaggio-società, cioè la vera e completa fusione dei due elementi.

${ }^{18}$ come strumenti di indagine, come fondamentali elementi dell'uomo proteso a capirsi, a chiarire il proprio significato.

${ }^{19}$ itinerario interiore, come epopea della coscienza, come "stream of consciousness".

${ }^{20}$ un romanzo rinnovato, liberato dal peso della tradizione e in grado di raccontare quell'universo ancora inesplorato che è la modernità.

${ }^{21}$ fondazione di una letteratura capace di parlare delle storie quotidiane degli uomini, delle loro vite di ordinarie passioni e di sentimenti comuni, ma non per questo meno sorprendenti e complicati, passa attraverso il sentimento di novità che la conoscenza delle opere di Svevo suggerisce.

22 sperimenta, magari inventa, una condotta narrativa, una poetica del romanzo, che certamente gli pare diversissima da quella che l'aveva assistito nella composizione di Una vita e Senilità.

${ }^{23}$ un discorso nascosto sotto il discorso di chi ufficilamente parla, si confessa, si giustifica, si difende, accusa, costruisce con frammenti a volte sconnessi e incompatibili la propria autoapologia o, almeno, una versione accettabili dei fatti.

${ }^{24}$ romanzo diventa un'enciclopedia di possibili immagini del mondo, senza che nessuna venga a trovarsi in posizione di privilegio.

${ }^{25}$ come strategia narrativa attuata intenzionalmente per contestare i valori culturali dall'interno della società.

${ }^{26}$ lascia sempre un'impressione di ambiguità che circonda i fatti, i gesti, i pensieri, le relazioni, la storia e le storie di Zeno.

${ }^{27}$ Io sto analizzando la sua salute, ma non ci riesco peché m'accorgo che, analizzandola, la converto in malattia. E, scrivendone, comincio a dubitare se quella salute non avesse avuto bisogno di cura o d'istruzione per guarire. Ma vivendole accanto per tanti anni, mai ebbi tale dubbio. (p.157)

${ }^{28}$ Il dubbio: ero io buono o cattivo? Il ricordo, provocato improvvisamente dal dubbio che non era nuovo: mi vedevo bambino e vestito (ne sono certo) tuttavia in gonne corte, quando alzavo la mia faccia per domandare a mia madre sorridente: "Sono buono o cattivo, io?" Allora il dubbio doveva essere stato ispirato al bimbo dai tanti che l'avevano detto buono e dai tanti altri che, scherzando, l'avevano qualificato cattivo. Non era affato da meravigliarsi che il bimbo fosse stato imbarazzato da quel dilemma. Oh incomparabile originalità della vita! Era meraviglioso che il dubbio ch'essa aveva già inflitto al bimbo in forma tanto puerile, non fosse stato sciolto dall'adulto quando aveva già varcata la metà della sua vita. (p.306) 
${ }^{29}$ - Benissimo! - dissi e avava tutto il suono di una concessione più che di un applauso. - Ma però non capisco perché, verso la chiusa, abbiate voluto scandere quelle note che il Bach segnò legate.

Io conoscevo la Chaconne nota per nota. C'era stata un'epoca in cui avevo creduto che, per progredire, avrei dovuto affrontare di simili imprese e per lunghi mesi passai il tempo a compitare battuta per battuta alcune composizioni del Bach. (...)

- Bach - aggiunsi - è tanto modesto nei suoi mezzi che non ammette un arco fatturato a quel modo. (p.131)

30 “15.4.1890 ore 4 1/2. Muore mio padre. U.S." Per chi non lo sapesse quelle due ultime lettere non significano United States, ma ultima sigaretta. E l'annotazione che trovo su un volume di filosofia positiva dell'Ostwald sul quale pieno di speranza passai varie ore e che mai intesi. Nessuno lo crederebbe, ma ad onta di quella forma, quell'annotazione registra l'avvenimento più importante della mia vita.

Mia madre era morta quand'io non avevo ancora quindici anni. Feci delle poesie per onorarla ció che mai equivale a piangere e, nel dolore, fui sempre accompagnato dal sentimento che da quel momento doveva iniziarsi per me una vita seria e di lavoro. Il dolore stesso accennava ad una vita più intensa. Poi un sentimento religioso tuttavia vivo attenuò e addolcì la grave sciagura. Mia madre continuava a vivere sebbene distante da me e poteva anche compiacersi dei successi cui andavo preparandomi. Una bella comodità! Ricordo esattamente il mio stato di allora. Per la morte di mia madre e la salutare emozione ch'essa m'aveva procurata, tutto da me doveva migliorarsi. 


\section{CONSIDERAÇÕES FINAIS}

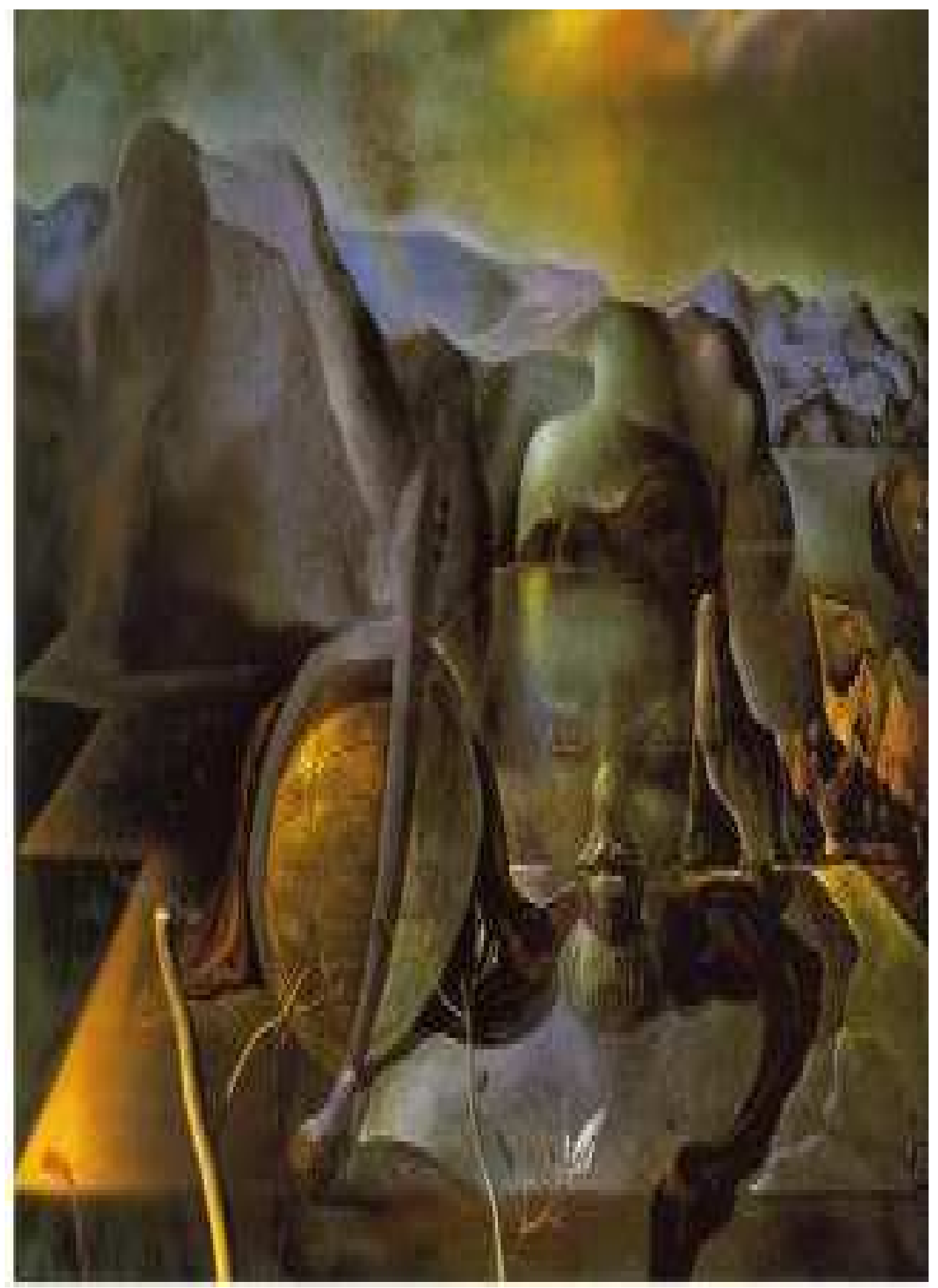

Enigma without end. Salvador Dali 
A palavra cria o real?

O real cria a palavra?

Mais difícil de aferrar:

Realidade ou alucinação?

Ou será a realidade Um conjunto de alucinações? Murilo Mendes

As inúmeras possibilidades de caminhos a serem percorridos pela narrativa zeniana parecem não se esgotar. A complexidade do romance A consciência de Zeno, objeto de nosso estudo, abriga em si infinitas veredas, por isso foi necessário o estabelecimento prévio de uma rota a ser seguida, para não nos perdermos nesse sinuoso labirinto discursivo. Desse modo, a partir do rumo que nos propusemos seguir, chegamos ao final de nossa viagem labiríntica. A fim de frisar e (não-)concluir este estudo, passemos à visão do fio que traçamos de antemão e que guiou e direcionou nosso percurso analítico.

Nosso ponto de partida, a introdução deste trabalho, deu-se através da questão a que nos dispusemos investigar: “Quem é Zeno Cosini?”. Assim, partimos em busca de uma possível constituição identitária para o senhor Cosini. Para tanto, debruçamo-nos sobre seu próprio discurso, lançando um olhar atento e, de certa forma, desconfiado de suas “confissões”. Servimo-nos, ainda, de textos teóricos para alicerçar nossas hipóteses, dispostas nos três capítulos deste estudo. Relembremos cada um deles, à guisa das considerações finais.

Na primeira rota, disposta no capítulo "Italo Svevo, solo una vita non può bastare", enveredamos pela apresentação do próprio escritor. Nosso intuito ao colocar em cena "flashes" da vida de Svevo, foi, além de mostrar sua história de perseverança e luta para ser reconhecido como escritor, procurar entender como ele apreendia o homem "sobrevivente" em um mundo em constantes transformações, um mundo que demonstra não entender os seus anseios e necessidades. Em meio à rapidez dos acontecimentos, esse homem termina por perder-se, por não entender seu verdadeiro papel na representação da maior obra de todas, a vida. 
O indivíduo, esboçado por Svevo, apresenta traços verdadeiramente humanos, ou seja, são seres "normais" constituídos por sentimentos contrastantes, movidos por ações "suspeitas" e paralisados por comportamentos hesitantes. Em sua narrativa, não há espaço para aquele homem que apresenta sempre a mesma conduta, que segue a mesma rotina. Assim, seus personagens podem ser egoístas e/ou altruístas, racionais e/ou emotivos, bons e/ou maus, vencedores e/ou perdedores, fortes e/ou fracos, agindo de acordo com o exigido pela situação ou acontecimento. Nesse processo, apreendemos um sujeito que necessita enunciar sua(s) história(s), em especial, as de fracasso, um sujeito à procura de seu autoconhecimento, em uma sociedade que preza, unicamente, pelo modo como ele deve apresentar-se, em seu grande espetáculo de aparências.

Vimos que o personagem, criado por Svevo, pode ser tomado como representante de todo o homem que, na verdade, poderia ser o próprio Svevo, uma vez que seu "eu" é tão múltiplo quanto o de seus personagens. É importante deixarmos claro que não tivemos a menor pretensão em fazer um estudo que visasse à comprovação de que os personagens svevianos, em especial Zeno Cosini, tratam-se, na realidade, de um auto-retrato fiel do próprio escritor. Como já ressaltamos, nosso intuito ao revisitar a vida de Svevo foi encontrar subsídios para tentar entender melhor o sujeito esboçado em suas narrativas, bem como nos aproximar do eu cosmopolita do escritor triestino.

Do contato com a biografia de Svevo, pudemos constatar as influências ideológicas, filosóficas e literárias sofridas, impressas em sua obra por intermédio do olhar e da voz de seus personagens. Constatamos, ainda, o movimentar-se de Svevo por dois ou mais “caminhos": comércio e literatura, cultura italiana e cultura alemã, Filosofia e Literatura. Isso apontou para a constituição cindida e múltipla do escritor triestino.

Essa fragmentação do indivíduo, dividido entre vários “eus”, muitas vezes sem saber qual escolher e que Svevo, inevitavelmente, carrega consigo, vem bem impressa na figura de 
seu personagem mais complexo, o burguês Zeno Cosini, sempre dividido, procurando viver e conviver com sua multiplicidade.

O percurso desse primeiro capítulo foi encerrado com a discussão das semelhanças entre criador, Italo Svevo, e criação, Zeno Cosini. Ainda que existam algumas afinidades intrigantes na vida de ambos, não acreditamos que Zeno Cosini seja, de fato, Italo Svevo. Podemos dizer, assim, que esse capítulo prestou-se como uma forma de aquecimento, um ensaio para podermos entender o processo de constituição do personagem Zeno Cosini, para tentarmos chegar a seu mais profundo "eu".

Na segunda rota, firmada no capítulo A criação de Zeno Cosini, nosso objetivo foi o de chegar, o mais próximo possível, a uma resposta plausível à pergunta que deu origem a nossa odisséia investigativa, "Quem é Zeno Cosini?". De antemão, buscamos entender o aparente silêncio que separa Zeno de seu irmão Emilio Brentani. Silêncio, como pudemos ver, fundamental na constituição e significação enigmática do senhor Cosini.

Diante do não-reconhecimento e da incompreensão por parte da crítica, com seus dois primeiros romances, Uma vida (1892) e Senilidade (1898), nosso escritor optou pelo silêncio, decidiu não mais escrever romances. Resignou-se em escrever contos e críticas literárias e em ler intensamente os grandes escritores. Tal silêncio, como bem notou o crítico Mario Lunetta (1976), foi estratégico, um período de reflexão e amadurecimento de nosso escritor para assim escrever sua obra prima, A consciência de Zeno. Desse modo, tal silêncio atuou, ativamente, no processo da significação ambígua, múltipla, transgressora e "escorregadia” desse narrador.

Destituído das qualidades e virtudes, tidas como modelo, Zeno apresenta-se a nós como um homem problemático, fraco, "mentiroso", covarde, enfim, um abastado burguês que só no final de suas memórias mostrará realmente que é um homem sagaz e competente para aplicar corretamente seus recursos e ousar investimentos inteligentes que garantem a estabilidade financeira e o status social de sua família. 
Aparentemente desajeitado e indeciso, Zeno dá a impressão de sempre contar, como bem observou o crítico Debenedetti (1995), com a sorte, terminando por “atrair”, na maioria das vezes, as escolhas certas. Isso pode ser notado em seu sensato matrimônio, cuja esposa ele "não" escolhera, mas que se revelou seu melhor "negócio", ao trazer-lhe um bem-estar maior à sua vidinha ociosa e dar-lhe a liberdade de ser ele mesmo, um fumante doente imaginário e contador de peripécias improváveis.

Mesmo diante de qualidades "marginais", descobrimos em Zeno o verdadeiro herói de seu tempo, um herói, como pudemos constatar através da obra Em louvor de anti-heróis: figuras e temas da moderna literatura européia, de Victor Brombert (2001), genuinamente humano. Muito distante do modelo medieval de herói, Zeno tem grande necessidade de falar, contestar, questionar, lançar dúvidas quanto aos valores aceitos e tidos como inabaláveis na sociedade em que (sobre-)vive. Em meio a suas turbulentas batalhas, Zeno consagrar-se-á como o verdadeiro vencedor de sua guerra interior, restabelecendo a tranqüilidade no seio de sua família e merecendo, assim, a classificação de verdadeiro herói.

Representante fiel das angústias e inquietações humanas, Zeno convidar-nos-á a conhecer seu obscuro universo. Presos à sua visão, como bem ressaltou Maria Celeste T. Ramos (2001), não temos outra alternativa a não ser seguirmos, desconfiando, contudo, de seu(s) olhar(es). Assim, na seqüência, fizemos um sucinto estudo do foco narrativo da obra, procurando entender os mecanismos da narrativa em primeira pessoa. Para tanto, servimo-nos dos estudos, principalmente, de Oscar Tacca (1978), Alfredo Leme Coelho de Carvalho (1981), Jean Pouillon (1974) e Vitor Manuel de Aguiar e Silva (1983), cujas obras dedicam boa parte na discussão da posição do olhar/voz do narrador no texto.

Pudemos averiguar que a narrativa em primeira pessoa dificulta uma caracterização mais nítida e precisa do "eu" narrante. O narrador em primeira pessoa, como ressalta Tacca (1978), carrega em seu cerne a dissimulação. Zeno, como sabemos, não foge a esse 
pressuposto, uma vez que seu discurso, como ele mesmo deixa claro, é todo pontuado por "meias-verdades". Verdades e mentiras entrelaçam-se e fundem-se, dando formas a um discurso cindido e ambíguo, usado por Zeno para deixar-nos em dúvida acerca de sua essência.

A problemática em torno de uma possível identidade para Zeno origina-se, como notamos, na própria estrutura da narrativa, que abriga dois Zenos, um narrador e o outro personagem. Um que narra e outro que é narrado. De antemão, já podemos notar que Zeno nasce de uma cisão, deverá percorrer seu caminho divido entre seu eu-narrador e o eunarrado, sendo que, conforme estudo de Vitor Manuel de Aguiar e Silva (1983), o decorrer do tempo termina por rasgar a identidade entre este eu-narrador e o eu-narrado. Nesse contexto, Zeno narrador não se reconhecerá, muitas vezes, na figura de Zeno narrado, ocorrendo, dessa forma, uma espécie de estranhamento entre eles.

Perdido entre o que ele é e o que foi, entre o que ele gostaria de ser e o que pode ser, Zeno continuará sua caminhada à procura de respostas, à procura de seu autoconhecimento. Nesse processo, como mostramos, as relações familiares serão importantes, uma vez que nos permitiram "individualizar" Zeno enquanto filho, pai, esposo, cunhado, enfim, um sujeito que busca manter intactas as aparências perante sua família e a sociedade a que pertence.

“Amor" não correspondido pela cunhada, ressentimento e ódio pelo cunhado, bem como adultério integram mais um capítulo da vida de nosso protagonista. Através de episódios como esses, temos delineado os contornos de uma sociedade burguesa, sempre voltada ao consumismo, às conveniências sociais, e preocupada, ainda, com as convenções pré-estabelecidas por ela. Um bom exemplo disso é o próprio casamento de Zeno. Aos olhos da sociedade, ele e a esposa formam um casal invejável; contudo, pela instância narrativa, sabemos que ambos casam-se movidos por alguns "interesses”. Augusta, a esposa, concretiza um ideal de vida, ao conquistar uma vida regada por luxo e conforto, encarnando 
magistralmente, o protótipo de esposa fiel, cuidadosa e preocupada com o marido e com os filhos, enfim, uma respeitada dama da sociedade italiana de sua época. Zeno, com o matrimônio, alcança uma vida mais tranqüila, repleta de confortos e mimos da esposa e se torna um exemplo de bom marido perante a sociedade, mas, às escondidas, continua seguindo seus desejos e instintos.

Dessa forma, as relações familiares que circundam Zeno foram importantes para desnudarmos um pouco mais de sua essência marota, lasciva e "marginal". Ainda que ele procure fugir a essa sua marginalidade, ao fazer uso das máscaras de um homem respeitado e íntegro, vimos que estas não se sustentam por todo o seu percurso narrativo.

Atentos ao cair dessas máscaras, prosseguimos nossa rota, buscando entender o processo de constituição da(s) identidade(s) de Zeno. Para tanto, buscamos apoio teórico principalmente em $O$ jogo do eu, do filósofo italiano Alberto Melucci (2004). De acordo com Melucci, o eu apresenta-se de forma instável, oscilante e múltipla. O homem já não consegue fixar um único eu para si.

Melucci relaciona a grande oscilação e multiplicidade do eu à fragmentação temporal que vivemos. Vivendo em uma sociedade em constantes transformações, o homem já não consegue equilibrar-se em um único pólo de seu eu, surgindo daí uma possível crise de identidade. Filho dessa sociedade, Zeno, como mostramos, terá dificuldades em escolher qual "persona" usar ou qual identidade escolher. Perdido em meio a seus vários "eus", Zeno recorrerá à escritura de suas memórias como uma maneira de tentar entender-se, reconhecerse, chegar, enfim, a seu mais profundo e complexo eu. Ao proceder assim, ele reconstrói-se, fixando uma identidade erguida na e pela narrativa.

Importante para caracterizá-lo e defini-lo, a escritura de sua vida é desencadeada por sua grande "doença", o vício pelo cigarro. Escrita e fumo, intrinsecamente ligados, foram fundamentais para que traçássemos os contornos, ainda que disformes, do "eu" oscilante, 
instável e múltiplo de Zeno. Sem sua obsessão pelo cigarro, ele não escreveria, sem escrever, conseqüentemente, sua história não existiria nem o grande personagem que se configura no romance.

Espécie de alicerce de sua identidade, sua doença permitirá não só que ele se autoanalise, mas também possa ser quem ele quiser ou, de fato, é. Funcionando como uma máscara, um escudo protetor, a obsessão pelo cigarro propiciará a Zeno a realização de desejos ocultos, que ele não poderia concretizar se fosse "são".

Essa suposta doença liga-se, como bem afirmou Mario Lunetta (1976), com a identidade mais profunda de Zeno, que não quer viver a "saúde" das regras sociais como a esposa vive, mas a "moléstia" da marginalidade. Assim, sua obsessão pelo cigarro funciona como uma chave para adentrarmos em seu mundo "real" e perscrutarmos seu eu mais profundo que, mesmo "doente" e entediado com a vida e com o ser humano, busca constantemente dar sentido a sua vida, preencher as lacunas deixadas por seu criador.

Nesse contexto, sua identidade está fadada a não terminar, a não concluir-se, assim como seu discurso, que pode ser enunciado outra vez, seu eu pode renascer das cinzas a todo instante. Aprisioná-lo em uma única identidade é impossível. A grandeza desse protagonista está justamente em sua duplicidade e fragmentação.

Já no último percurso de nossas veredas investigativas, intitulado Escrevo, logo existo, retomamos o processo de escrita, pilar fundamental no alicerce da caracterização de Zeno, apontando, ainda, para os traços modernos e de inovação da narrativa sveviana.

Importante, como já ressaltamos, o escrever é colocado na obra de Svevo, conforme Matteo Palumbo (2007), como algo totalmente inerente à natureza de seus personagens, espécie de alimento para suas almas incompletas, suplemento necessário para preencher e dar cor a suas vidas vazias. A escrita, como vimos em Zeno, legitimará sua existência e permitirá que ele se veja por inteiro. 
Através da escrita, nos aproximamos um pouco mais de Zeno e de sua maneira de ver a vida como uma incurável doença, cuja cura ele buscará por intermédio da escritura de suas memórias. Svevo parece mesmo ter construído, de acordo com Paolo Puppa (1995), a escritura como a única e possível salvação para seus personagens que, apáticos e sem compreender a vida, escreverão. Assim, Zeno precisa da escrita como o doente precisa do medicamento.

Svevo, como vimos, instaura uma narrativa com traços modernos e inovadores que pode ser enquadrada na terceira fase da Modernidade, de acordo com a classificação elaborada por Marshall Berman (2007). Essa fase apresenta como característica predominante a fragmentação e multiplicidade do homem.

A "nova" narrativa, fixada por Svevo, incompreendida inicialmente por romper com o cânone tradicional da época, por superar a ideologia naturalista, dá ênfase ao sujeito. O escritor triestino coloca em cena o que podemos chamar de escritura do "eu".

Svevo usará a narrativa, de acordo com Luti (1961), como meio de investigação, como algo essencial para o homem entender-se, iluminando, assim seu próprio significado. Dessa forma, é na narrativa que o homem buscará conhecer-se, buscará respostas a seus questionamentos, na maioria das vezes, de cunho existencialista. É o que acontece com Zeno que utilizará a narrativa para conhecer-se, construindo, com o fluir da narrativa, sua(s) identidade(s).

A narrativa de Zeno caracteriza-se, principalmente, pela multiplicidade de suas vozes, sendo esta a grande invenção de Svevo, como observou Lavagetto (2004). Múltipla e "escorregadia", essa narrativa cria sempre a ambigüidade nos relatos narrados e a ironia coroa essa ambigüidade e vigora como elemento fundador da dualidade perenemente apresentada no texto. 
Do início ao fim, o romance é todo pontuado pela ironia, importante por gerar a ambigüidade e a desconfiança do que foi enunciado/escrito. Para entendermos melhor os meandros do discurso irônico, buscamos fundamentação teórica nos estudos de Beth Brait (1996) e Linda Hutcheon (2000). Por meio de seus estudos, pudemos constatar que o discurso irônico de Zeno, além de demonstrar a duplicidade de seu caráter, contribui para velar sua verdadeira identidade.

Nesse ponto, encerramos nosso percurso investigativo, desencadeado pela curiosidade, pelo interesse em entendermos um pouco mais da essência de um narrador mentiroso confesso que se apresenta a nós, sob o véu de um discurso ambíguo, passível de várias interpretações.

Da nossa pergunta inicial, “Quem é Zeno Cosini?”, temos a dizer que, como pudemos averiguar, mais importante do que estabelecermos uma única identidade ao senhor Cosini, é entendê-lo, aceitando suas várias faces escondidas por máscaras que ele precisa utilizar para continuar a viver em um sociedade, na qual o "parecer" tem mais valor do que o "ser".

Assim, o fio de Ariadne de sua constituição identitária está no seu próprio discurso. Se existe uma identidade para ele esta se encontra na narrativa, ou seja, na possibilidade de conceder ao narrador a habilidade de contestar as regras da sociedade em que vive, mesmo demonstrando o contrário, de modo a permanecer na multiplicidade de sua marginalidade, caracterizando-se, então, como um narrador que só pode ser visto e compreendido através de uma leitura prismática. 


\section{REFERÊNCIAS BIBLIOGRÁFICAS}

\section{CORPUS E TEXTOS DE SVEVO}

SVEVO, Italo. La coscienza di Zeno. Perugia: Guerra Edizioni, 1996.

A consciência de Zeno; tradução Ivo Barroso. Rio de Janeiro: Nova Fronteira, 2006.

Romanzi e “continuazioni”. Milano : Mondadori Editrice, 2004.

\section{TEXTOS SOBRE SVEVO}

APIH, Elio. La società triestina negli anni di Svevo. In PETRONIO, Giuseppe. Il caso Svevo. Palermo: Palumbo, 1988, pp. 9-36.

BARILLI, Renato. La linea Svevo-Pirandello. Milano : Mursia, 1977.

BERNARDINI, Aurora F. Existência e consciência em Italo Svevo. O Estado de São Paulo, 11-08-1993, Caderno 2, p.3. de resenhas $\mathrm{N}^{\circ} 29, \mathrm{p} .4$.

A consciência de Svevo. Folha de São Paulo. 09-08-1997, Jornal

BON, A. Come leggere “La coscienza di Zeno” di Italo Svevo. Milano: Mursia, 1977.

BOSI, Alfredo. Céu, inferno: ensaios de crítica literária e ideológica. São Paulo: Ática, 1988.

BROMBERT, Victor. Em louvor de anti-heróis: figuras e temas da moderna literatura européia; tradução José Laurenio de Melo. São Paulo: Ateliê Editorial, 2001.

CALIFANO, Mimma Bresciani. Svevo e il nuovo romanzo europeo : al strategia dell'antieroe. In CALIFANO, Mimma Bresciani (a cura di) Modelli e stili di conoscenza nella scienza e nell'arte del novecento. Leo S. Olschki : cidade, 2000

CARRAVETTA, Peter. Svevo soggetto postmoderno. In. BUCCHERI, Mauro; COSTA, Elio. Italo Svevo tra moderno e postmoderno. Ravenna : Longo Editore, 1995.

CASTRO, Silvio. Svevo, da incompreensão à consagração. O Estado de São Paulo, 15-091985, p.8.

CLAAR, Micaela Pretolani. Guida alla lettura di Svevo. Milano: Mondadori, 1986.

FEDERICI, Corrado. L'eccentricità e l'ex-centricità dei protagonisti sveviani. In BUCCHERI, Mauro; COSTA, Elio. Italo Svevo tra moderno e postmoderno. Ravenna : Longo Editore, 1995.

KEZICH, Tullio. Svevo e Zeno : Vite Parallele. Milano : Pesce d'oro, 1970. 
KRYSINSKI, Wladimir. La coscienza, l'alterità e il discorso della narrazione in Italo Svevo. In BUCCHERI, Mauro; COSTA, Elio. Italo Svevo tra moderno e postmoderno. Ravenna : Longo Editore, 1995.

LAURETIS, Teresa de. La sintassi del desiderio: Struttura e forme del romanzo sveviano. Ravenna : Longo Editore, 1976.

LAVAGETTO, Mario. Svevo e la crisi del romanzo europeo. In ROSA, Alberto Asor. Letteratura italiana del novecento - Bilancio di in secolo. Torino : Einaudi, 2000.

Il romanzo oltre la fine del mondo. In SVEVO, Italo. Romanzi e continuazioni. Milano : Mondadori Editrice, 2004.

LUNETTA, Mario. Invito alla lettura di Svevo. Torino : Mursia, 1976.

LUTI, Giorgio. Italo Svevo e altri studi sulla letteratura del primo novecento. Milano: Lerici, 1961.

MARTINELlI, Luciana. L' ultimo Svevo. IN: PETRONIO, Giuseppe. Il caso Svevo. Palermo. Palumbo, 1988, pp. 101-128.

MAXIA, Sandro. Svevo e la prosa del novecento. Roma : Laterza. 1990.

MIORIN, Cristiane Vanessa. Narcisismo literário: espelhamento, procura e fuga em A consciência de Zeno e "O meu ócio", de Italo Svevo. São José do Rio Preto: 2006. Dissertação (Mestrado em Letras/ Área de Teoria da Literatura). IBILCE - Instituto de Biociências Letras e Ciências Exatas - UNESP - Universidade Estadual Paulista "Júlio de Mesquita Filho".

PALUMBO, Matteo. Il romanzo italiano da Foscolo a Svevo. Roma: Carocci, 2007.

PUPPA, Paolo. Italo Svevo : la scrittura in scena. In CARLÀ, Marisa; ANGELIS, Luca de. L'ebraismo nella letteratura italiana del Novecento. Palermo : G. B. Palumbo \& C. Editore, 1995.

RAMOS, Maria Celeste Tommasello. A representação em Memórias póstumas de Brás Cubas e A consciência de Zeno. São José do Rio Preto: 2001. Tese (Doutorado em Letras/ Área de Teoria da Literatura). IBILCE - Instituto de Biociências Letras e Ciências Exatas - UNESP - Universidade Estadual Paulista "Júlio de Mesquita Filho".

ROQUE, Araguaia Solange de Souza. Minha consciência daria um romance: O personagem sujeito do(ao) inconsciente na interface Literatura e Psicanálise. São Jóse do Rio Preto, 2005. Tese (Doutorado em Letras). IBILCE - Instituto de Biociências, Letras e Ciências Exatas - UNESP - Universidade Estadual Paulista "Júlio de Mesquita Filho".

SANCHES, Maria Teresa Nunes. Memórias póstumas de Brás Cubas e A consciência de Zeno: Representações históricas das sociedades brasileira e italiana. São José do Rio Preto: 2003. Dissertação (Mestrado em Letras/ Área de Teoria da Literatura). IBILCE - Instituto de Biociências Letras e Ciências Exatas - UNESP - Universidade Estadual Paulista "Júlio de Mesquita Filho".

TEDESCO, Natale. La coscienza letteraria del novecento : Gozzano, Svevo ed altri esemplari. Palermo : Flaccovio Editore, 1999. 
VICENTINI, Marzia Terenzi. Encontro com Svevo. São Paulo: 1984. Tese de Doutoramento (Área de Teoria Literária e Literatura Comparada). Faculdade de Filosofia, Letras e Ciências Humanas da Universidade de São Paulo.

VITTORINI, Fabio. Commento "La coscienza di Zeno" . In SVEVO, Italo. Romanzi e continuazioni. Milano : Mondadori Editrice, 2004.

\section{BIBLIOGRAFIA GERAL}

AGUIAR E SILVA, Vitor Manuel de. Teoria da Literatura. Coimbra: Livraria Almedina, 1983.

ALMANSI, Guido. Introduzione al La novella di ser Ciappelletto. Venezia: Marsiglio, 1992.

ASOR ROSA, A. Storia della letteratura italiana. Firenze: La Nuova Italia, 1985.

BAKHTIN, Mikhail. Estética da criação verbal. São Paulo: Martins Fontes, 1992.

Questões de Literatura e de Estética: a teoria do romance; tradução Aurora Fornoni Bernardini et all. São Paulo: Annablume : Hucitec, 2002.

BARBERI SQUAROTTI, Giorgio (org.) Literatura italiana: linhas, problemas, autores. São Paulo: Nova Stella: Istituto Cultural Ítalo-Brasileiro: Editora da Universidade de São Paulo, 1989.

BOSI, Alfredo. Fenomenologia do olhar. In NOVAES, Adauto (org.) O olhar. São Paulo: Companhia das Letras, 1995.

BERMAN, Marshall. Tudo o que é sólido desmancha no ar: a aventura da modernidade; tradução Carlos Felipe Moisés, Ana Maria L. Ioratti. São Paulo : Companhia das Letras, 2007.

BRAIT, Beth. Ironia em perspectiva polifônica. Campinas, SP : Editora da Unicamp, 1996.

BRUSCAGLI, Riccardo. CARETTI, Ianfranco. LUTI, Giorgio. Letteratura Italiana con saggi critici. Milano : Edizione A.P.E, 1990.

CALVINO, Italo. Seis propostas para o próximo milênio; tradução Ivo Barroso. São Paulo: Companhia das Letras, 1990.

CARVALHO, Alfredo Leme Coelho de. Foco narrativo e fluxo de consciência: questões de teoria literária. São Paulo: Pioneira, 1981.

DEBENEDETTI, Giacomo. Italiani del novecento. Firenze: Giunti, 1995. . Il romanzo del novecento. Milano: Garzanti, 1987.

DEBORD, Guy. A sociedade do espetáculo; tradução Estela dos Santos Abreu. Rio de Janeiro: Contraponto, 1997.

ECO, Umberto. Entre a mentira e a ironia; tradução Eliana Aguiar. Rio de Janeiro: Record, 2006. 
FALQUI, Enrico. Novecento letterario italiano. Firenze : Vallecchi editore, 1970.

GARCIA, Wladimir A.C. A imagem do artista. IN: ANTELO, Raul(org.). Identidade \& Representação. Florianópolis, 1994, pp. 441-448.

GROSSER, Hermann. Narrativa. Milano: Casa Editrice G. Principiato, 1986.

HUTCHEON, Linda. Teoria e política da ironia; tradução de Julio Jeha. Belo Horizonte : Editora UFMG, 2000.

KEHL, Maria Rita. Fenomenologia do olhar. In NOVAES, Adauto (org.) Masculino/Feminino: o olhar da sedução. São Paulo: Companhia das Letras, 1995.

LANDOWISKI, Eric. Presenças do outro; tradução Mary Amazonas Leite de Barros. São Paulo: Perspectiva, 2002.

MARQUES, Luiz. O modelo e a imagem. Bravo. № 47, pp. 13-15, agosto de 2001.

MELUCCI, Alberto. O jogo do eu; tradução Adriano R. Marinho et all. São Leopoldo/RS: Unisinos, 2004.

MORETTI, Franco. Il romanzo. Torino: Giulio Einaudi Editore. 1950.

ORLANDI, Eni Pulccinelli. As formas do silêncio no movimento dos sentidos. Campinas/SP: Editora da Unicamp, 1995.

PONZIO, Augusto. La rivoluzione bachtiniana: Il pensiero di Bachtin e l'ideologia contemporanea. Bari: Levante, 1997.

POUILLON, Jean. O tempo no romance; tradução Heloysa de Lima Dantas. São Paulo: Cultrix, 1974.

ROSENFELD, Anatol. Texto/contexto I. São Paulo : Perspectiva, 1996.

SALINARI, C.; RICCI, C.; SERRI, G. Il novecento italiano: cultura e letteratura. Roma : Editori Laterza, 1983.

TACCA, Oscar. As vozes do romance. Coimbra: Livraria Almedina, 1978.

\section{SITES CONSULTADOS NA INTERNET}

- http:/www.atuttascuola.it/relazioni/ítalo_svevo.htm

- http://www.repubblicaletteraria.it/ItaloSvevo.html

- http://www.allposters.com/gallery.asp 